\title{
AVALIAÇÃO CRONOLÓGICA DO USO DA TERRA E SEU IMPACTO NO AMBIENTE DA MICROBACIA HIDROGRÁFICA DO CÓRREGO DO CEVEIRO DA REGIÃO DE PIRACICABA - SP
}

\section{Peterson Ricardo Fiorio}

Engenheiro Agrônomo

Orientador: Prof. Dr. JOSÉ ALEXANDRE MELO DEMATTÊ

Dissertação apresentada à Escola Superior de Agricultura "Luiz de Queiroz", Universidade de São Paulo, para obtenção do título de Mestrè em Agronomia, Área de Concentração: Solos e Nutrição de Plantas.

P I R A C I C A B A

Estado de São Paulo - Brasil

Fevereiro - 1998 
FIORIO, Peterson Ricardo

Avaliação cronológica do uso da terra e seu impacto no ambiente da Microbacia Hidrográfica do Córrego do Ceveiro da região de Piracicaba - SP / Peterson Ricardo

Fiorio. - Piracibaba, 1998.

$$
114 \text { p. : il. }
$$

Dissertação (mestrado) - Escola Superior de Agricultura Luiz de Queiroz, 1998. Bibliografia.

1. Cana-de-açúcar 2. Conservação do solo 3. Cronologia 4. Erosão 5.

Fotointerpretação 6. Impacto ambiental 7. Microbacia do Corrégo do Ceveiro 8. Uso da terra. 1. Título 
AVALIAÇÃo CRONOLÓGICA DO USO DA TERRA E SEU IMPACTO NO AMBIENTE DA MICROBACIA HTDROGRÁFICA DO CÓRREGO DO CEVEIRO dA REGIÃo DE PIRACICABA - SP

PETERSON RICARDO FIORIO

Aprovada em: 31.03 .1998

Comissão julgadora:

Prof. Dr. José Alexandre Melo Demattê

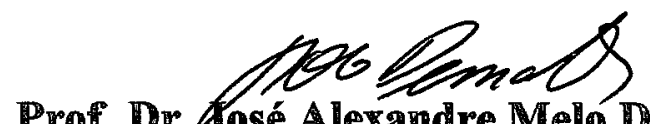

Proffo Dr.bosé Alexandre Melo Demattê 


\section{Aos meus Avós}

Não digas: Este que me deu corpo é meu Pai

Esta que me deu corpo é minha Mãe

Muito mais teu Pai e tua Mãe são os que te fizeram

Em espirito

E esses foram sem número

Sem nome

De todos os tempos

Deixaram o rastro pelos caminhos de hoje

Todos os que já vieram

E andam fazendo-te dia a dia

Os de hoje, e os de amanhã.

(Cecilia Meireles)

\section{Em especial}

Os maiores homens que conheci, a cujo olhar nem a terra, nem o céu tinham segredos, eram humildes e sabiam perfeitamente o grau de respeito que cabia a cada criatura.

De alguém que se orgulha em chamá-lo

de avô 
Aos meus pais

Antonio Carlos e Rosemari

A maior necessidade deste mundo é de confiança e de amor

Aos meus irmãos

Anderson e Vinícius

Por todos esses anos de convivência e de amor mútuo

Aos meus familiares

Sejam sempre os mesmos

Sempre outros

Mas sempre...dentro de tudo 


\title{
AGRADECIMENTOS
}

\begin{abstract}
A Deus
Que é a força de todas as crenças, de todos os povos, em qualquer parte do Universo
\end{abstract}

Ao meu Orientador Prof. Dr. José Alexandre Melo Demattê, pela amizade, dedicação e confiança que depositou em mim. Sem dúvida contribuindo para transformarme nesse profissional de hoje.

Aos integrantes da banca examinadora nas pessoas do Prof. Dr. Geraldo Victorino de França e Dr. Hélio do Prado.

A Comissão de Pós-graduação do curso de Solos e Nutrição de Plantas da ESALQ/USP, pela oportunidade concedida.

Ao Prof. Dr. Gerd Sparovek, pela amizade, dedicação e constante ajuda neste trabalho.

A todos os funcionários do Departamento de Ciência do Solo, pela amizade e ajuda dispensada.

A todos os que participaram no desenvolvimento da dissertação, nas pessoas de Enio Fraga, Marcos Nanni, Miguel Cooper, Fabio Ribeiro, Fábio e Luciana Dias, Marco Nogueira, Rodrigo Maule, Alexandre Leite, Rogério Campos, Danieli Focht, Mara Weill, Simone Ranieri, Marcia Sá e Roberta Sparovek. 


\section{SUMÁRIO}

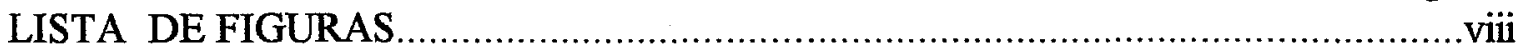

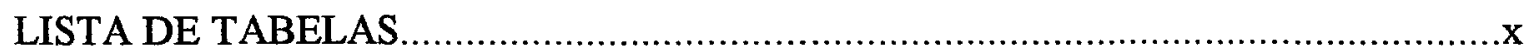

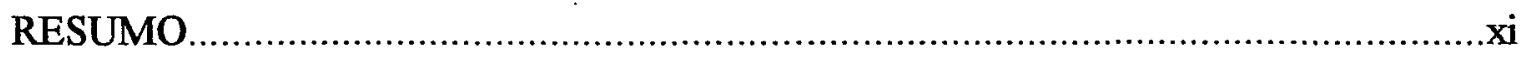

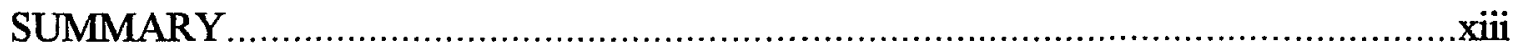

1.INTRODUÇÃ

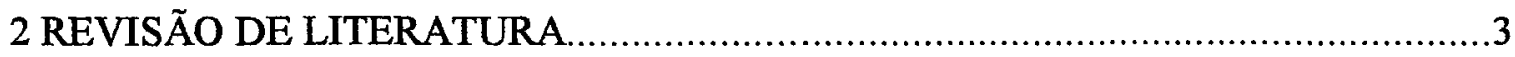

2.1 Escala da Microbacia Hidrográfica como Unidade de Estudo....................................

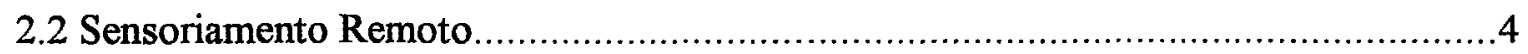

2.2.1 Utilização de imagens aerofotográficas no mapeamento do uso da terra.................5

2.2.2 Chaves de interpretação para fotografias aéreas.................................................

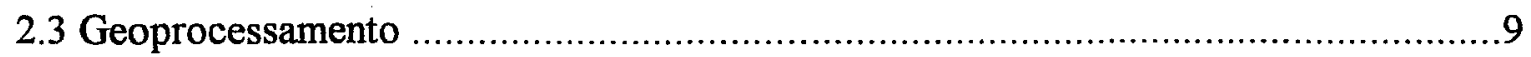

2.3.1 Sistemas de Informação Geográfica (SIG's)...............................................10

2.3.2 Componentes básicos de um Sistema de Informação Geografica (SIG)..................11

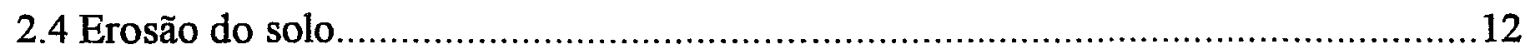

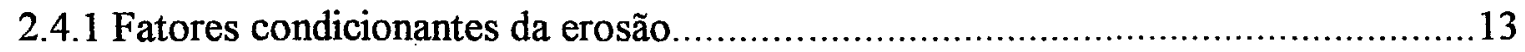

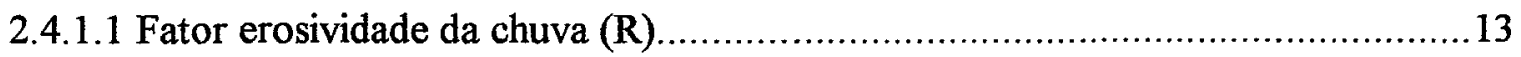

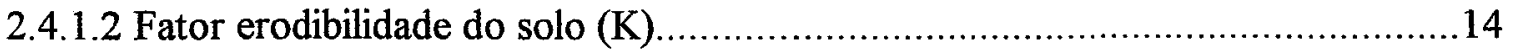

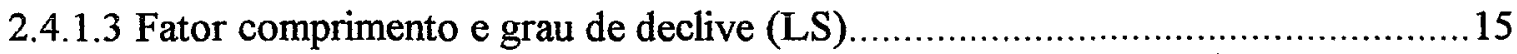

2.4.1.4 Fatores uso-manejo do solo $(\mathrm{C})$ e práticas conservacionistas $(\mathrm{P}) \ldots \ldots \ldots \ldots \ldots \ldots \ldots . . .16$

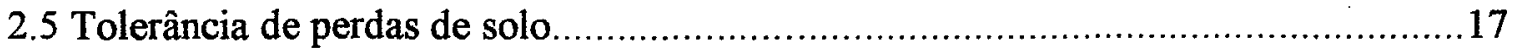

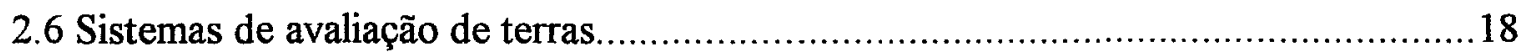

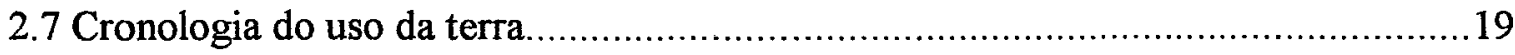

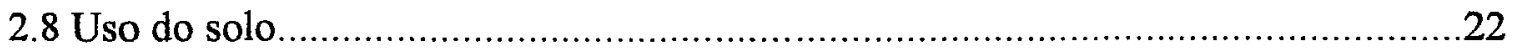

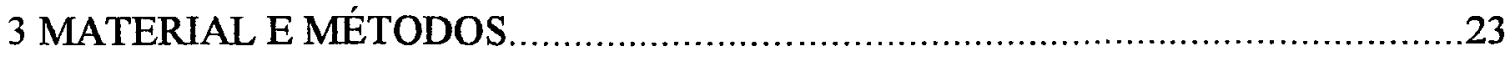

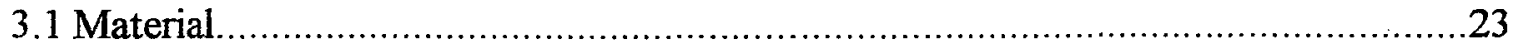

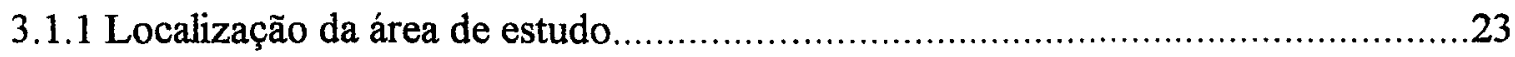

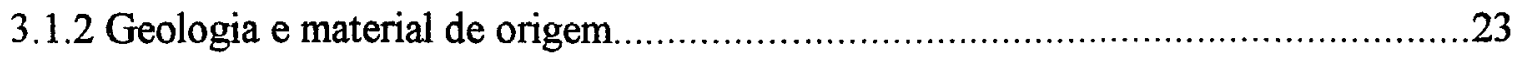


Páginas

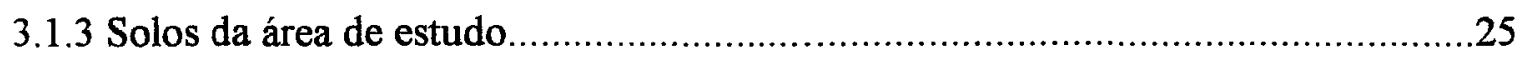

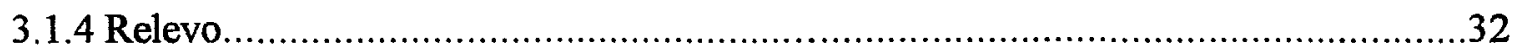

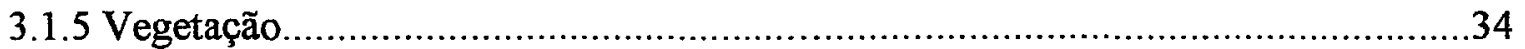

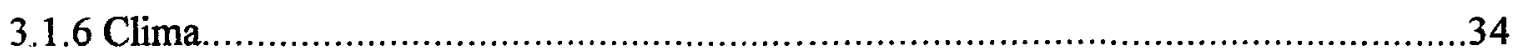

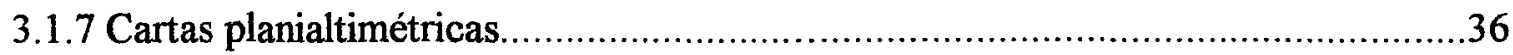

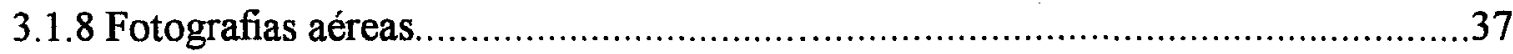

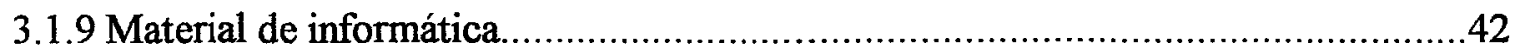

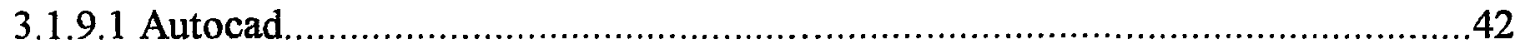

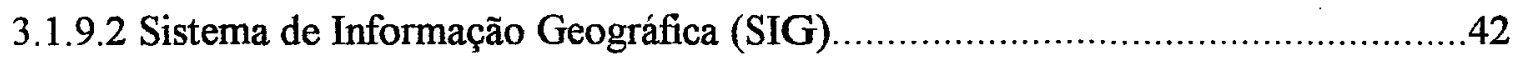

3.1.9.3 Sistema de Análise Ambiental para Planejamento Agrícola (SAMPA) ................43

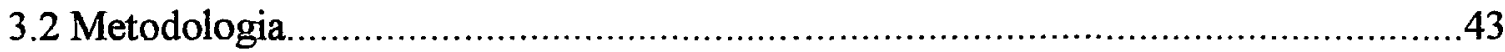

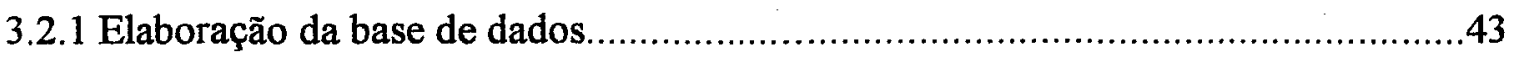

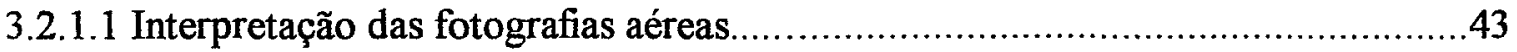

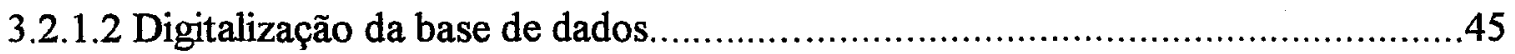

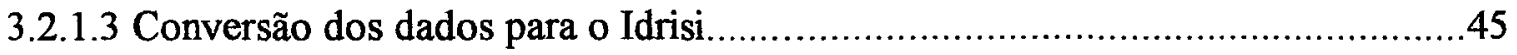

3.2.2 Processamento dos dados no programa Idrisi.................................................

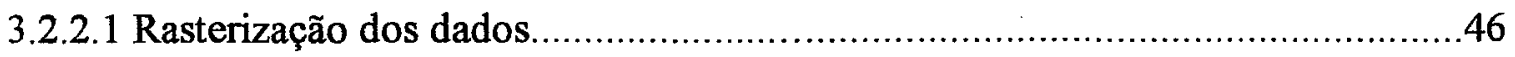

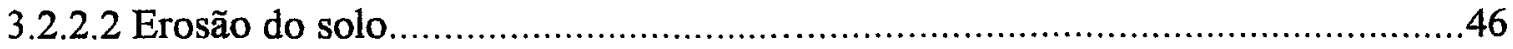

3.2.2.3 Obtenção dos fatores da Equação Universal de Perdas de Solo (EUPS)

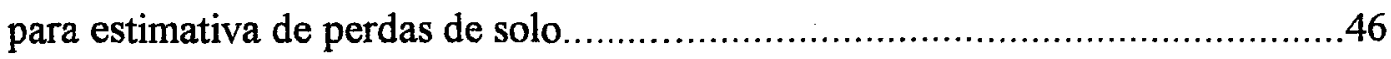

3.2.2.4 Sistema de Análise Ambiental para Planejamento Agrícola (SAMPA)..............53

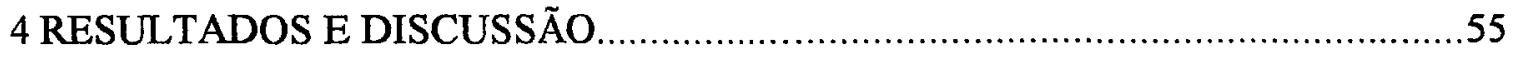

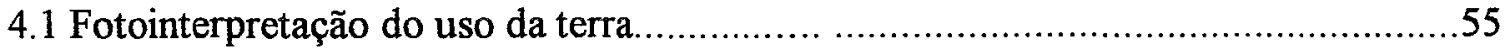

4.2 Cronologia do uso da terra na Microbacia Hidrográfica

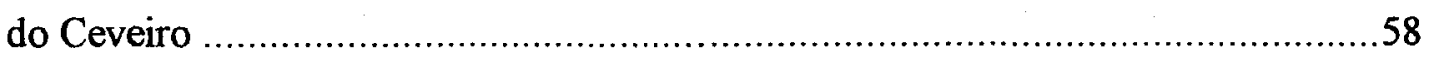

4.2.1 Evolução das culturas na microbacia em função das classes de solo e declive. 
Páginas

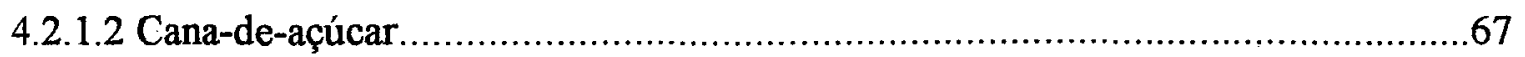

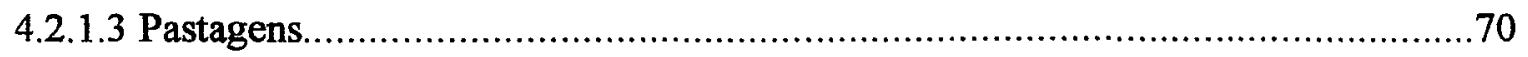

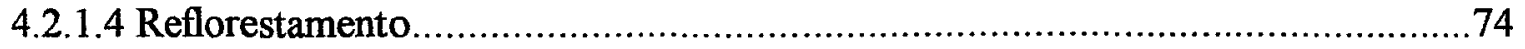

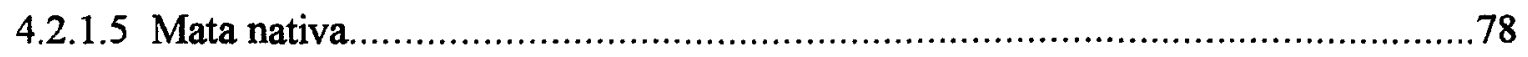

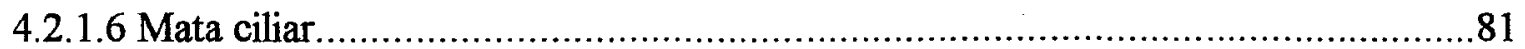

4.3 Perdas de solo de acordo com o tipo de cultura na Microbacia Hidrográfica

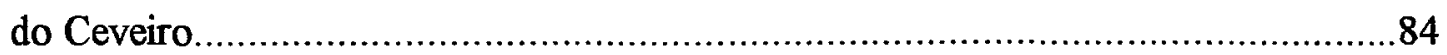

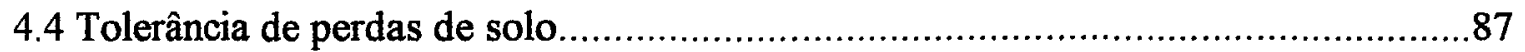

4.5 Aptidão agrícola ou potencialidade agrícola das terras........................................92

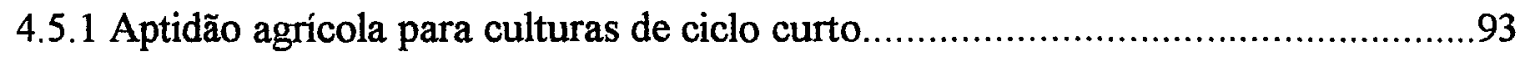

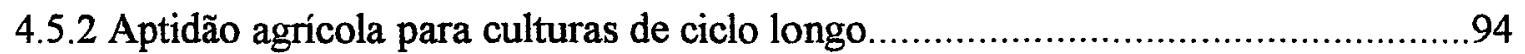

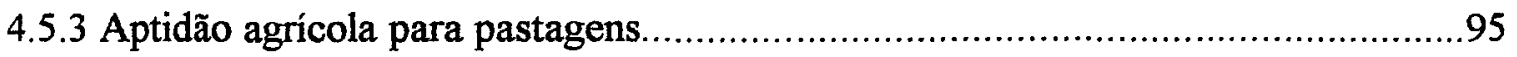

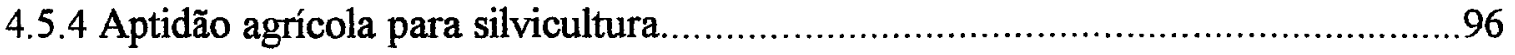

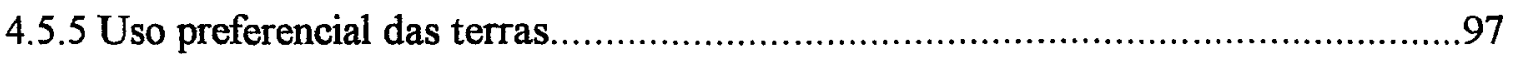

4.5.6 Uso preferencial x Uso da terra em 1995 (Atual) - Impacto Ambiental .................98

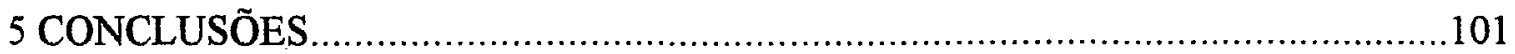

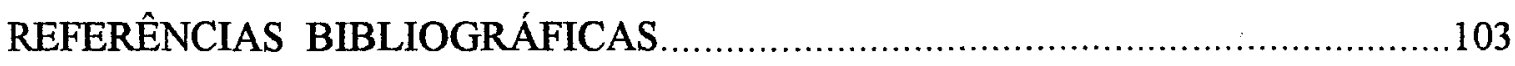




\section{LISTA DE FIGURAS}

Páginas

1 Localização da Microbacia Hidrográfica do Córrego do Ceveiro no Município de Piracicaba - SP.

2 Corte transversal na Microbacia Hidrográfica do Córrego do Ceveiro, mostrando a deposição das formações geológicas......................................................25

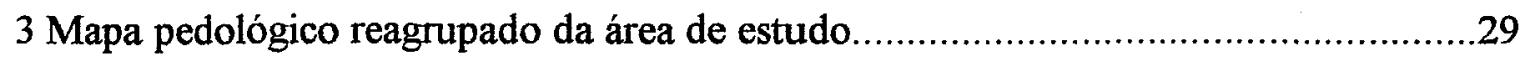

4 Bloco diagrama representando o relevo da Microbacia Hidrográfica do

Córrego do Ceveiro.

5 Mapa de declividades da área de estudo. 34

6 Balanço hidrico do Município de Piracicaba, SP. 36

7 Fotografia aérea da Microbacia Hidrográfica do Ceveiro do ano de 1962, escala 1:25.000. 38

8 Fotografia aérea da Microbacia Hidrográfica do Ceveiro do ano de 1965 , escala 1:60.000 39

9 Fotografia aérea da Microbacia Hidrográfica do Ceveiro do ano de 1978 , escala 1:35.000

10 Fotografia aérea da Microbacia Hidrográfica do Ceveiro do ano de

1995, escala 1:25.000.

11 Representação esquemática da metodologia utilizada.

12 Representação esquemática da obtenção dos mapas de perdas de solos

(1962, 1965, 1978, 1995) pelo método descrito por Ranieri (1996). 48

13 Cenário de uso da terra na Microbacia Hidrográfica do Ceveiro em 1962. 61

14 Cenário de uso da terra na Microbacia Hidrográfica do Ceveiro em 1965. .61

15 Cenário de uso da terra na Microbacia Hidrográfica do Ceveiro em 1978 .................62

16 Cenário de uso da terra na Microbacia Hidrográfica do Ceveiro em 1995.................62

17 Evolução do uso da terra na Microbacia Hidrográfica do Ceveiro em ha/ano............63

18 Evolução das culturas anuais nos solos da área (ha). 
Páginas

19 Evolução das culturas anuais em suas respectivas classes de declive (ha) .................66

20 Evolução da cana-de-açúcar nos solos da área (ha).................................................68

21 Evolução da cana-de-açúcar em suas respectivas classes de declive (ha)..................69

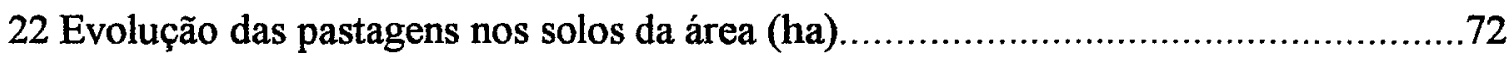

23 Evolução das pastagens em suas respectivas classes de declive (ha) ........................73

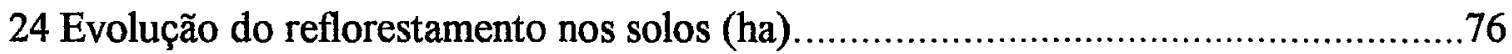

25 Evolução do reflorestamento em suas respectivas classes de declive (ha) ................77

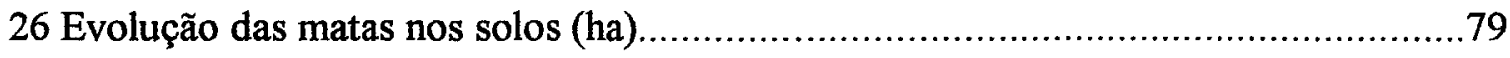

27 Evolução das matas em suas respectivas classes de declives (ha) .............................80

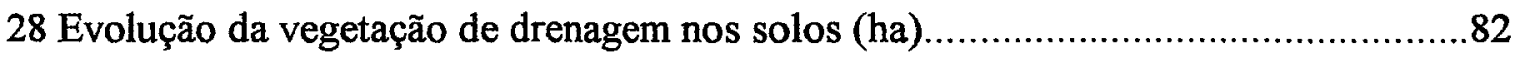

29 Evolução da vegetação de drenagem em suas respectivas classes de declive (ha)......83

30 Média ponderada das perdas de solos por cultura em cada ano de estudo................85

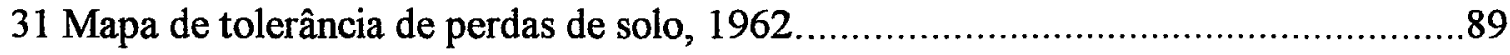

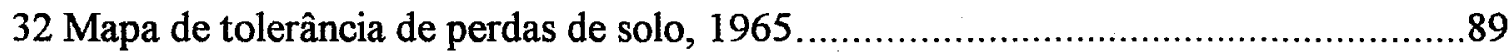

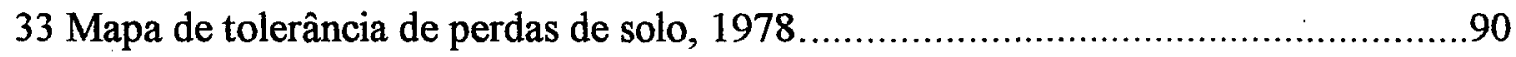

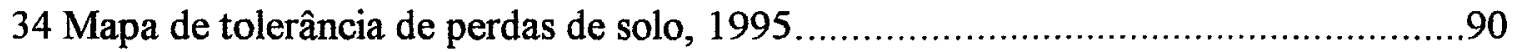

35 Dimensão das áreas de tolerância de perdas de solo (ha)..........................................91

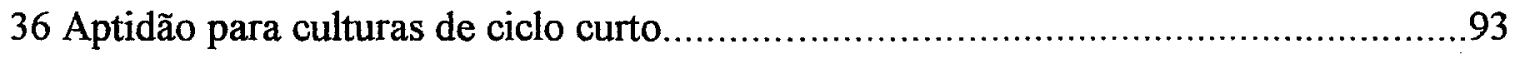

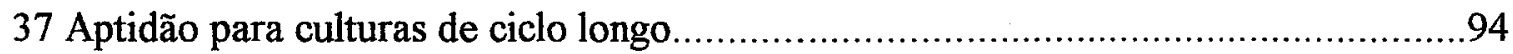

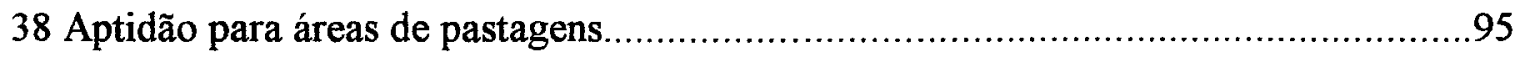

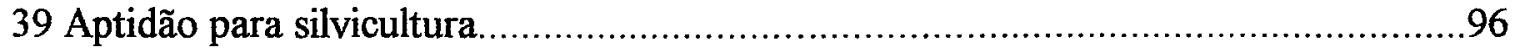

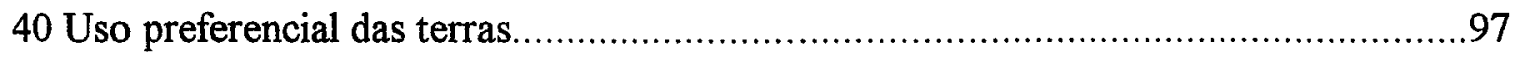

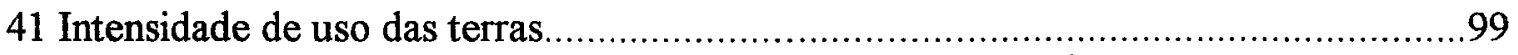




\section{LISTA DE TABELAS}

Páginas

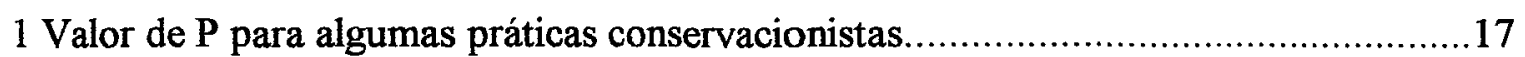

2a Resultados da análise química das unidades de mapeamento da área de estudo.........29

$2 \mathrm{~b}$ Resultados da análise granulométrica das unidades de mapeamento

da área de estudo.

3 Dados climatológicos do Município de Piracicaba - SP ................................................35

4 Valores de erodibilidade para os solos da Microbacia Hidrográfica do Ceveiro...........49

5 Fatores uso-manejo e práticas conservacionistas para as culturas encontradas...........52

6 Características do uso da terra de acordo com a escala da fotografia aérea ................57

7 Dimensão em ha, das áreas de uso da terra da Microbacia Hidrográfica

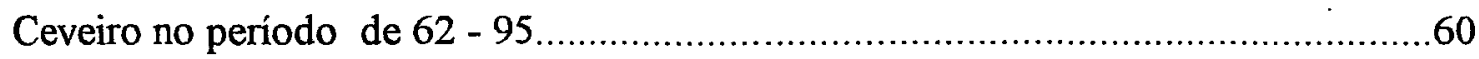

8 Áreas em hectares de culturas anuais de acordo com os respectivos solos da área......65

9 Áreas em hectares de culturas anuais nas classes de declive.....................................66

10 Áreas em hectares de cana-de-açúcar nos solos.....................................................68

11 Áreas em hectares de cana-de-açúcar nas classes de declive ..................................69

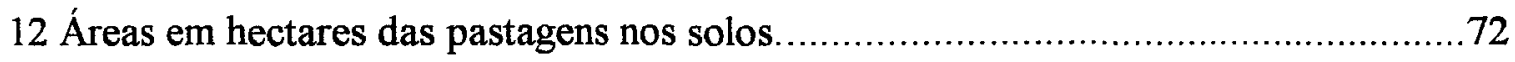

13 Áreas em hectares das pastagens nas classes de declive ..........................................

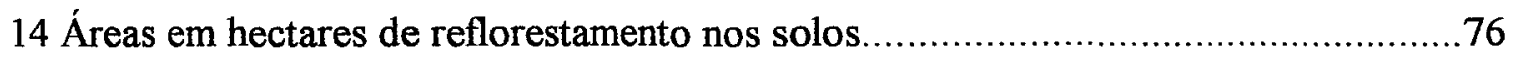

15 Áreas em hectares de reflorestamento nas classes de declive.................................77

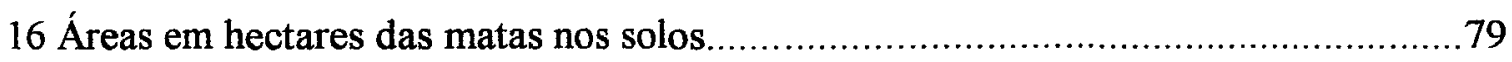

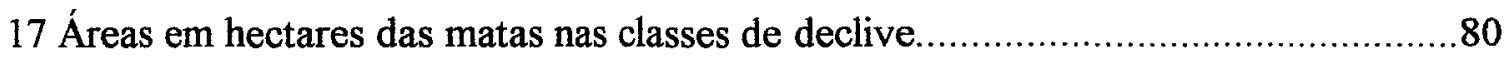

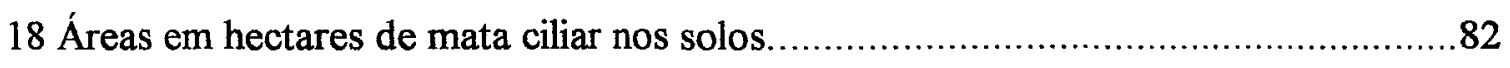

19 Áreas em hectares de mata ciliar nas classes de declive .......................................83

20 Perdas médias de solo em tonelada/hectare por tipo de cultura ................................85

21 Dimensão das áreas em hectares de níveis de tolerância de perdas de solo …...........92

22 Áreas em hectares de uso preferencial e uso da terra em 1995 ..............................100 


\begin{abstract}
AVALIAÇÃo CRONOLÓGICA DO USO DA TERRA E SEU IMPACTO NO AMBIENTE DA MICROBACIA HIDROGRÁFICA DO CÓRREGO DO CEVEIRO DA REGIÃo DE PIRACICABA - SP
\end{abstract}

\author{
Autor: PETERSON RICARDO FIORIO \\ Orientador: Prof. Dr. JOSÉ ALEXANDRE MELO DEMATTÊ
}

\title{
RESUMO
}

Este trabalho foi conduzido com os objetivos de avaliar a cronologia do uso da terra entre os anos de 1962 e 1995, o grau de erosão dos solos ocupados e o impacto das ações antrópicas na Microbacia Hidrográfica de Ceveiro, cujos solos estão basicamente representados por Solos Litólicos e Podzólicos Vermelho Amarelos. Para tanto, técnicas de fotointerpretação e geoprocessamento foram utilizadas, permitindo uma rápida e eficiente integração entre os dados levantados.

Os resultados demostraram que a utilização de fotografias aéreas permitiu avaliar a evolução do uso da terra na área de estudo, durante um período de 33 anos, correspondente à época analisada.

A cultura anual que em 1965 ocupava cerca de $42 \%$ da área, foi reduzida para 0,15\% em 1995 enquanto que a cana-de-açúcar teve um acréscimo de $16 \%$ para $66 \%$ no mesmo período sendo, portanto, a grande responsável pera redução de áreas de cultura anual na microbacia. $O$ maior crescimento da cultura de cana-de-açúcar se deu entre os anos de 1978 à 1995, com um acréscimo de 795 ha, perfazendo um total de aproximadamente $40 \%$ da área da microbacia, caracterizado principalmente pela influência dos incentivos governamentais através do Proalcool.

O impacto ambiental mais facilmente destacado pela expansão da cana-de-açúcar refere-se a redução da área de espelho d'água, da represa responsável pelo abastecimento 
da Vila de Artemis, localizada na microbacia. Implantada em 1978, sua área reduziu-se de 12 ha para 6 ha, devido ao assoreamento.

Em relação às perdas de solo, os resultados obtidos demonstraram que o fator de erodibilidade do solo $(\mathrm{K})$ foi o mais representativo para o cálculo, quando levou-se em consideração uma mesma cultura. As menores perdas foram observadas nos solos Litólicos devido a sua textura argilosa. As diferenças de perdas de solo entre as culturas são explicadas pelo fator uso-manejo, que é maior para a cultura anual em relação à cana-de-açúcar. No período analisado, ocorreu redução das áreas cuja tolerância às perdas foi estabelecida em mais de 10 vezes o valor estabelecido, devido principalmente a substituição das culturas anuais pela cana-de-açúcar.

Em relação à capacidade de uso, os resultados demostraram que $48 \%$ da área estava sendo utilizada abaixo do seu potencial, sendo que $27 \%$ estavam sendo utilizadas adequadamente e $23 \%$ de forma inadequada. O uso do sistema SAMPA possibilitou o estabelecimento de uso preferencial indicando a forma mais adequada de distribuição das áreas para as diferentes culturas. 


\title{
CHRONOLOGICAL EVALUATION OF THE LAND USE AND ITS ENVIROMENTAL IMPACT IN THE WATERSHED OF CEVEIRO STREAM, PIRACICABA - SP
}

\author{
Author: Autor: PETERSON RICARDO FIORIO \\ Adviser: Prof. Dr. JOSÉ ALEXANDRE MELO DEMATTÊ
}

\section{SUMMARY}

This work was conducted with the objective of evaluating the chronology of the land use during the years of 1962 and 1995, the degree of erosion of the soils and the impact of the antropic actions in the Ceveiro watershed, which presents Entisols, Alfisols and Ultisols. Fotointerpretation geoprocessing techniques were used, allowing a fast and efficient integration of the data.

The results showed that the use of aerial photos allowed to evaluate the evolution of the land use in the study area, during a 33 year-old period, corresponding to the analyzed time.

The annual crops that in 1965 occupied about $42 \%$ of the area, was reduced to $0,15 \%$ in 1995 while the sugar-cane increased from $16 \%$ for $66 \%$ in the same period being, therefore, responsible for the reduction of the areas of annual crops in the watershad. The largest growth of the sugar-cahe ocurred during the years of 1978 to 1995 , with an increment of 795 ha, that is approximately $40 \%$ of the area of the watershed, due mainly to the influence of the government incentives through Proalcool.

The environmental impact highlighted by the expansion of the sugar-cane refers to the reduction of the water reserve area responsible for the provisioning of the Villa of Artemis, located in the watershed. Construced in 1978, its area reduced from 12 ha to 6 ha due to silting. 
In relation the soil losses, the results obtained showed that the factor of soil erodibility $(\mathrm{K})$, was the most representative for the calculations, when a same culture was taken into consideration. The smallest losses were observed in the Entisols due their loamy texture. The soil loss differences among the cultures are explained by the usemanagement factor, that is larger for the annual cultures in relation to sugar-cane. In the analyzed period, reduction of the areas, whose tolerance to the losses were established, occurred in more than 10 times the established value, due mainly to the substitution of the annual crops by the sugar-cane.

In relation to use capacity, the results showed that $48 \%$ of the area was being used below its potential, and $27 \%$ was being used appropriately and $23 \%$ in an inadequate way. The use of the system SAMPA facilitated the establishment of preferential uses indicating the adapted form of distribution of the areas for the different crops. 


\section{INTRODUÇÃO}

A tecnologia de produção nem sempre leva em consideração o melhor manejo dos recursos naturais, o que pode promover a degradação do ambiente. Assim, com o passar dos tempos, o homem vem procurando encontrar um ponto de equilibrio entre o uso racional dos recursos naturais e os sistemas de produção agrícola. Portanto, devido aos graves desequilibrios no ambiente, deve-se avaliar adequadamente o seu uso.

O uso da terra pode ser estudado por técnicas de sensoriamento remoto. A fotografia aérea, é um dos produtos mais antigos e ainda muito utilizado, devido à resolução oferecida e a facilidade de manuseio. A fotointerpretação é útil na discriminação de culturas em épocas diferentes, permitindo detectar elementos e situações importantes, facilitando tomadas de decisões futuras. Com o avanço computacional a partir das décadas de 40 e 50 e posterior desenvolvimento do sensoriamento remoto, surgiram os Sistemas de Informação Geográficas (SIG’s). Estes constituem-se de poderosas ferramentas de armazenagem e manipulação de dados do meio ambiente.

A cana-de-açúcar vem sendo produzida no Brasil desde o período colonial, sendo que hoje representa uma atividade econômica de grande importância para o País . À partir de 1973, com o Programa Nacional do Álcool (Proalcool), que visava a substituição da gasolina pelo etanol, teve-se um grande aumento nas áreas cultivadas principalmente no sudeste brasileiro. Este aumento também foi notado na Região de Piracicaba, tradicional produtora de cana-de-açúcar, onde a porcentagem de área cultivada foi elevada de $35 \%$ (62.362 ha) em 1962, para $49 \%$ (86.819 ha) em 1991 (Sparovek \& Lepsch, 1992). 
Esta expansão agrícola ocorreu principalmente em solos de maior suscetibilidade à erosão, uma vez que as terras com maior potencial agrícola já eram ocupadas com canade-açúcar antes de 1962. O histórico do uso da terra ao longo do tempo se torna necessário para verificar a adequabilidade de sua utilização.

A Microbacia Hidrográfica do Córrego do Ceveiro, localizada no Município de Piracicaba (SP) abrange uma área de 2.200 ha, limitada a montante pela vila de Santana e a jusante pelo Distrito de Artemis. Esta área vem sendo utilizada por muitos anos com cultivo de cana-de-açúcar, devido à proximidade de usinas de processamento. Essa bacia foi responsável pelo abastecimento de água potável de aproximadamente 2.000 habitantes, a qual é coletada numa represa localizada no final do Córrego do Ceveiro, tendo portanto, grande importância ambiental. Neste aspecto, tornou-se de vital importância a adequação dos sistemas de produtivos às condições ecológicas disponíveis, juntamente para a manutenção da produtividade da terra a longo prazo.

A hipótese que se levanta é a de que a ocupação desordenado da cultura da canade-açúcar na região, devido aos incentivos governamentais (Proalcool), acarretou problemas de ordem ambiental, tais como, erosão do solo e poluição dos recursos hídricos. Portanto, o presente trabalho tem os seguintes objetivos:

a) Avaliar a cronologia do uso da terra de 1962 até 1995, através, de fotointerpretação;

b) Avaliar o grau de erosão da área nas mesmas datas;

c) Avaliar a ocupação agrícola e seu impacto no ambiente;

d) Verificar qual a melhor utilização da terra.

Com isso, o trabalho visa compreender as relações entre as ações antrópicas e o impacto ambiental na Microbacia Hidrográfica do Ceveiro. 


\section{REVISÃO LITERATURA}

\subsection{Escala da microbacia hidrográfica como unidade de estudo}

A bacia hidrográfica pode ser definida como unidade fisica, caracterizada como uma área de terra drenada por um determinado curso d'água e limitada, perifericamente, pelo chamado divisor de águas (Valente, 1976). Segundo Moldan \& Cerny (1994) a microbacia do ponto de vista hidrológico, pode ser considerada como a menor unidade de paisagem capaz de integrar todos os componentes relacionados com a qualidade e disponibilidade de água como: atmosfera, vegetação natural, plantas cultivadas, solos, rochas subjacentes, corpos d'água e paisagem circundante. Ambientalmente, pode-se dizer que a bacia hidrográfica é a unidade ecossistêmica e morfológica que melhor reflete os impactos das interferências antrópicas, tais como a ocupação das terras com as atividades agrícolas (Jenkins et al., 1994).

As ações governamentais relacionadas ao manejo e conservação dos solos e recursos hídricos são elaboradas nesta escala. Segundo Bertolini (1993) "através do Programa Estadual de Microbacias Hidrográficas, os Governos Estadual e Municipal e as associações de agricultores estão iniciando um trabalho visando adequar o aumento da produção de alimentos para atender ao consumo interno e gerar excedentes para o mercado externo, melhorando o padrão de vida do agricultor e ao mesmo tempo utilizando de modo racional e integrado os recursos naturais do solo, da água, flora e fauna". Da mesma forma, em outros estados como no Paraná, há programas de Microbacias Hidrográficas com resultados muito positivos, principalmente na adequação 
do uso e manejo das terras de maneira a proporcionar uma produção agrícola economicamente viável e ambientalmente sustentável Mariano ${ }^{1}$, citado por Ranieri (1996). Ainda segundo o autor a bacia hidrográfica é considerada como área de influência a partir da resolução de $n^{\circ}$ 001/86 do CONAMA (Conselho Nacional do Meio Ambiente), de 1981, passando a ser considerada como área a ser analisada no estudo de impacto ambiental. $\mathrm{O}$ decreto $\mathrm{n}^{\circ} 36787$, de 18 de maio de 1993, da legislação do estado de São Paulo, regulamenta a lei $n^{\circ} 7663$, que discrimina grupos de bacias hidrográficas sendo esta divisão hidrográfica aprovada pelo Conselho Estadual de Recursos Hídricos CRH.

Segundo Demétrio (1977) ocorre uma perda de detalhes das características de rede de drenagem quando comparadas as escalas de 1:8.000 para 1:60.000.

\subsection{Sensoriamento remoto}

"Sensoriamento remoto pode ser definido como a ciência e a arte de se obter informações sobre um determinado objeto, área ou fenômeno, através de dados coletados por um equipamento, que não entra em contato direto com o objeto, área ou fenômeno estudado" (Crepani, 1993).

Segundo Young (1976) do ponto de vista de utilidade, as técnicas de sensoriamento remoto podem ser divididas em dois grupos: (1) fotografias aéreas, obtidas em avião (tanto pancromáticas como coloridas), (2) técnicas de sensoriamento remoto, compreendendo o uso de outros tipos de sensores instalados em plataformas aéreas (aviões) ou orbitais (satélites).

Com o intuito de gerar mapas topográficos, Arago em 1840, propôs o uso de fotografias aéreas, tendo como suporte o exaustivo programa desenvolvido por Laussedat a partir de 1850 . Em 1853, as fotografias aéreas foram utilizadas para a definição de rotas, antes mesmo da guerra civil americana. Também nessa década, as

\footnotetext{
${ }^{1}$ MARIANO, M.T. Uma analise da participação da sociedade civil na gestão dos recursos hídricos do Estado de São Paulo. São Carlos, 1996. Dissertação (Mestrado) Escola de Engenharia de São Carlos, Universidade de São Paulo.
} 
fotografias foram de grande importância nos levantamento geológicos, principalmente na pesquisa de petróleo e na Arquitetura ao redor de 1858 por Mcydenbauer (Politano, 1980). Ainda nessa mesma década, vários campos da ciência se beneficiaram com essa nova técnica, particularmente na agricultura, com propósito de mapeamento Quackenbush $^{2}$, Davis ${ }^{3}$ e Fischer ${ }^{4}$ citados por Politano (1980).

No Brasil, podemos citar a região amazônica, onde foram realizados levantamentos sistemáticos pelo projeto RADAM, que corresponderam a uma faixa territorial de dois milhões de quilômetros quadrados. Os principais propósitos destes foram a elaboração de cartas topográficas, de vegetação, de geologia, de geomorfologia, de solos e da drenagem superficial, entre outros (Paiva et al., 1976).

Graças a visão panorâmica e a riqueza de detalhes, as fotografias aéreas se tornaram indispensáveis nos estudos da superficie terrestre, pois permitem explicar fenômenos da paisagem de grande importância nos levantamentos de recursos naturais (Koffler, 1982).

Segundo Steiner (1970) vários pesquisadores em todo mundo, a partir de 1950, se dedicaram a utilização de fotografias aéreas para a identificação detalhada de culturas agrícolas.

Apesar do advento das imagens de satélites comerciais tais como LANDSAT e SPOT, e pelo fato destas apresentarem uma resolução espacial de 30 a 10 m nas imagens respectivamente, diminuindo o detalhamento do alvo (ocupação urbana, identificação de vegetação, lotes e edificações, detalhes de uso dos solos entre outros), ainda se justifica a necessidade da utilização das fotografias aéreas em estudos ambientais (Lobão, 1996).

\footnotetext{
${ }^{2}$ QUACKENBUSH, RS. Development of photo interpretation. In: AMERICAN SOCIETY OF PHOTOGRAMETRY. Manual of photographic interpretation. Washington, 1960. Cap. 1, p. 1-18.

${ }^{3}$ DAVIS, R.E.; FOOTE, F.S.; KELLY, J.E. Surveying: theory and pratice. New York: Mc Gran Hill, 1966. 1196p.

${ }^{4}$ FISCHER, W.A. BADGLEY, P.; ORR, D.G. et al. History fo remote sensing. In: REEVES, R. G.; ANSON, AG.; LANDER, D. Manual of remote sensing. Virginia: American society of Photogrammetry, 1975. p. 27-50.
} 


\subsubsection{Utilização de imagens aerofotográficas no mapeamento do uso da terra}

A avaliação do uso da terra é de grande importância no registro e acompanhamento das alterações causadas pelo homem ao longo do tempo. Dessa forma, é possível se notar graves desequilíbrios no meio ambiente causados a partir do uso inadequado dos recursos naturais. Segundo Alves (1990) o uso adequado da terra, bem como dos recursos naturais, vem a ser um passo decisivo para uma agricultura racional. Assim sendo, a utilização do sensoriamento remoto tem se mostrado de grande valia.

O registro cartográfico da distribuição das comunidades vegetais (uso da terra) é muito importante para a comunidade científica, sendo ainda indispensável para o planejamento e ocupação a nível local ou regional (Politano et al., 1990).

Segundo Koffler (1982), a vegetação, seja natural ou organizada pelo homem, pode ser considerada como sendo a mais facilmente observável, pois cobrindo o solo, é o principal objeto que interage com a radiação eletromagnética, a qual é responsável pela formação da imagem fotográfica.

Segundo Rabben (1960) a utilização das fotografias aéreas se deve a três motivos principais:

a) a grande área abrangida da superficie terrestre, passível de ser representada em cada fotografia;

b) as imagens tridimensionais da superficie terrestre e dos objetos nela localizados, proporcionada pelos pares estereoscópicos;

c) o caráter permanente das imagens dos objetos e as condições favoráveis de trabalho.

Para se identificar na fotografia aérea um objeto nunca visto anteriormente ou para o entendimento de objetos já identificados, o intérprete se utiliza do "princípio da convergência de evidências" desenvolvido por Colwell. Podem existir vários indícios sobre a identidade de um objeto desconhecido. Entretanto, nenhum desses indicios é infalível, mas se todos, ou a maioria deles apontar para a mesma conclusão, esta será provavelmente correta Rabben (1960). 
Rabben (1960), Ray (1963) e Ricci \& Petri (1965) argumentam que a fotointerpretação deve apresentar duas fases: na primeira é realizada a observação, coleta de dados, medição e identificação dos objetos presentes nas fotografias aéreas, a segunda fase envolve estudos de dedução de informações, que são aplicados na solução de um problema.

\subsubsection{Chaves de interpretação para fotografias aéreas}

Segundo Santos et al. (1980) para a interpretação do uso da terra em imagens fotográficas, as características mais importantes são: tonalidade, textura, padrão, forma, dimensão, sombra, cor, sítio topográfico e relações com o aspecto.

Koffler et al. (1979) através de estudo em fotografias pancromáticas, na escala 1:35.000, desenvolveram uma chave de interpretação para as culturas estudadas, apresentando as seguintes descrições:

Cultura temporária: baixa ocorrência de carreadores, baixa subdivisão em glebas quando as áreas são extensas, ausência de diferentes estágios de desenvolvimento simultâneos, curvas de nível mais freqüentes e evidentes dentro das glebas.

a) Cultura estabelecida (de inverno)

Textura: fina e contínua

Porte: rasteiro e baixo

Tonalidade: cinza claro ou médio

b) Restos Culturais (características diferenciais)

Tonalidade: cinza claro

Aspectos associados: restos enleirados, bandeiras (área de amontoamento da colheita)

c) Pastagens

Textura: fina, homogênea, ligeiramente aveludada

Porte: rasteiro, não perceptível ao estereoscópio

Tonalidade: cinza claro e médio

Aspectos associados: aguadas, bebedouros, cercas, currais e trilhas 
d) Reflorestamento: formações arbóreas homogêneas, instaladas pelo homem Textura: fina e média

Porte: médio e alto

Tonalidade: cinza médio e escuro intenso

Aspectos associados; telhado uniforme, em geral limites regulares e carreadores definidos

e) Mata

Textura: média e grossa

Porte: alto

Tonalidade: cinza médio e escuro

Aspectos associados: telhado desuniforme, geralmente apresenta limites irregulares e ausência de carreadores

f) Capoeira

Textura: fina e/ou média

Porte: médio

Tonalidade: cinza médio

Aspectos associados: telhado uniforme ou desuniforme

Marchetti \& Garcia (1978) apresentaram a seguinte descrição, como chave de interpretação, para culturas anuais e cafezal:

Culturas anuais: formas regulares ausência de sombras, textura aveludada, muitas vezes marcheteada, tonalidade clara e intermediária (preto e branco).

Cafezal: formas regulares, talhões pequenos, espaçamento característico, ausência de sombras, porte baixo, textura imperceptível das árvores, tonalidade intermediária (preto e branco).

Segundo Borges et al. (1993) através de estudos de evolução e mapeamento do uso da terra, chegaram a seguinte chave de interpretação para fotografias aéreas, na escala 1:35.000:

Cultura anual: textura fina, porte baixo, tonalidade cinza claro e aspectos associados - curvas de nível. 
Cana-de-açúcar: textura fina aveludada, porte rasteiro ou baixo médio, tonalidade cinza muito claro à médio, telhado uniforme e aspectos associados - carreadores e curvas de nível.

Cultura perene: textura granular, porte médio, tonalidade cinza e aspectos associados - individualização das plantas, espaçamentos largos e configuração geométrica das glebas.

Mata: textura grosseira, porte alto, tonalidade cinza, telhado não uniforme e aspectos associados - ausência de carreadores e limites irregulares.

Reflorestamento: textura fina, porte alto, tonalidade cinza, telhado uniforme e aspectos associados - glebas com limites regulares e carreadores definidos.

Pastagem: textura fina, porte rasteiro, tonalidade cinza claro a médio e aspectos associados - árvores isoladas para sombreamento.

Área urbana: textura grosseira, tonalidade cinza médio, telhado não uniforme e aspectos associados - quarteirões, ruas, prédios, casas e aspectos geométricos.

\subsection{Geoprocessamento}

Apesar de distintas, as áreas de Sensoriamento Remoto e Geoprocessamento desenvolveram várias tecnologias, as quais vêm sendo muito utilizadas nos últimos anos, tornando-se mutuamente dependentes, integrado em estudos de uso da terra e monitoramento de processos evolutivos, não se concebendo a utilização de uma sem o apoio da outra (Rocha et al., 1996).

O geoprocessamento pode ser definido como um conjunto de tecnologias especializadas na coleta e tratamento de informações espaciais, bem como no desenvolvimento e uso de sistemas que possam utilizá-las. A esses sistemas dá-se a denominação de Sistemas de Informação Geográfica - SIG (Rodrigues, 1990). 


\subsubsection{Sistemas de Informação Geográfica (SIG)}

Os Sistemas de Informação Geográfica - SIG são aqueles destinados à aquisição e tratamentos de dados georreferenciados (referenciados espacialmente), permitindo a manipulação de dados de diversas fontes, recuperando, combinando informações e efetuando vários tipos de análises (Alves, 1990).

Segundo Câmara (1993) uma das principais características de um sistema de geoprocessamento é a capacidade de armazenar, recuperar e analisar mapas num ambiente computacional.

Os "SIG's" possibilitam a realização de tarefas, antes manuais, facilitando análises complexas, através da possibilidade de integração de dados de diversas fontes e de criação de um banco de dados geocodificados, segundo manual do SIG do INPE (1988).

A utilização de Sistemas de Informação Geográfica (SIG’s), sob suporte da informática, vem permitindo o zoneamento de áreas de forma mais eficiente, substituindo os métodos mais onerosos e de dificil manipulação (Sano et al.,1990).

Segundo Teixeira et al. (1990) a área de informática vêm apresentando um grande avanço tecnológico, com ampla disseminação do uso de computadores em todas as áreas do conhecimento.

Os "SIG's" foram desenvolvidos a partir dos anos 40 e 50 , com o avanço computacional e devido a grande quantidade de dados em decorrência da evolução do sensoriamento remoto (Teixeira et al., 1992).

Existe uma grande necessidade em se utilizar de SIG's para se obter e manipular um banco de dados georreferenciados, constituindo-se em poderosas ferramentas, capazes de integrar dados obtidos de diferentes fontes como as imagens orbitais, os mapas planialtimétricos, os mapas geológicos, entre outros (Assunção et al., 1990). 
Segundo Davidson (1992), é de grande importância o uso de SIG's para o armazenamento e manipulação de dados sobre a evolução do uso da terra e monitoramento das mudanças que eventualmente ocorram.

Silva et al. (1993) estudaram o desmatamento em Ubajara (CE) num período de 27 anos. Concluíram que o sistema de análise georreferenciada foi de grande importância para a visualização das mudanças espaço temporais.

\subsubsection{Componentes básicos de um Sistema de Informação Geográfica - SIG}

Os SIG's possuem três importantes componentes: equipamento computacional (hardware); um conjunto de módulos aplicativos (software) e um contexto organizacional apropriado, sendo que para o sistema funcionar satisfatoriamente, os seus componentes devem estar balanceados (Burrought, 1986).

Segundo Teixeira et al. (1992), um SIG pode ser visto como um sistema composto por um banco de dados, um conjunto de softwares que executạm as operações sobre os dados (análise espacial) e pelo hardware.

Os SIG's, apresentam basicamente quatro módulos ou etapas: (1) entrada de dados; (2) gerenciamento de dados e armazenamento; (3) manipulação e análise de dados e (4) exibição dos dados (Vettorazzi, 1992).

Assad (1995) exemplifica as etapas de um trabalho utilizando-se de um SIG, são:

a) Definição: onde deve-se definir uma escala de trabalho e unidade de medidas;

b) Entrada de dados: digitalização dos mapas, em mesa digitalizadora;

c) Conversão: consistindo na transformação de todos os dados vetorias (vindos da digitalização) para a forma raster (matricial);

d) Análise Geográfica: na qual é possível de se obter novos dados (Planos de informação), utilizando-se funções de "reclassificar por classes", "cruzar" e "calculo de áreas";

e) Saída: os resultados obtidos impressos. 


\subsection{Erosão do solo}

A erosão do solo é condicionada pela evolução do meio físico e a ação do homem como agente modificador das condições naturais. Os fatores naturais mais importantes estão ligados à natureza do solo (erodibilidade), à morfologia do terreno (declividade) e clima (erosividade das chuvas). Os fatores antrópicos se relacionam à ocupação das terras e às características de cada cultivo, os quais são referenciados pelo uso atual através de seu uso-manejo e de práticas conservacionistas (Bueno, 1994).

Bertoni \& Lombardi Neto (1990) apresentaram a Equação Universal de Perdas de Solo (EUPS), como uma equação empírica utilizada para estimar as perdas de solo por erosão laminar. Foi desenvolvida em 1954, no "National Runoff and Soil Data Center", do Agricultural Research Service, na Universidade de Purdue, EUA. Posteriormente, a equação evoluiu para o modelo revisado por Wischmeier \& Smith em 1978, com a incorporação de novos dados disponíveis.

A EUPS apresenta-se como:

$$
\text { A }=\text { R.K.L.S.C.P }
$$

onde:

$\mathrm{A}=$ perda média anual de solo por unidade de área, $\mathrm{t} / \mathrm{ha}$;

$\mathrm{R}=$ fator erosividade das chuvas, $\mathrm{MJ} / \mathrm{ha} \cdot \mathrm{mm} / \mathrm{ha}$;

$\mathrm{K}=$ fator erodibilidade do solo, $\mathrm{t} / \mathrm{ha} /(\mathrm{MJ} / \mathrm{ha} \cdot \mathrm{mm} / \mathrm{ha})$;

$\mathrm{L}=$ fator comprimento de encosta, $\mathrm{m}$;

$S=$ fator grau do declive, $\%$;

$\mathrm{C}=$ fator uso e manejo;

$\mathrm{P}=$ fator práticas conservacionistas. 
Os fatores $\mathrm{R}, \mathrm{K}, \mathrm{L}$ e S são dependentes das condições naturais e os fatores $\mathrm{C}$ e $\mathrm{P}$ são relacionados às formas de ocupação e uso das terras (fatores antrópicos).

\subsubsection{Fatores condicionantes da erosão}

\subsubsection{Fator erosividade da chuva ( $R$ )}

O poder erosivo das chuvas tropicais é elevado devido a sua distribuição e energia cinética das gotas de chuva, (El-Swaify et al. 1982), este fato é importante para se conhecer o desencadeamento da fase inicial da erosão.

"O fator chuva $(R)$ é um índice numérico que expressa a capacidade da chuva, esperada em determinada localidade, de causar erosão em uma área sem proteção" (Bertoni \& Lombardi Neto, 1990).

Wischmeier (1959) considera a energia cinética $(E)$ e a intensidade média em 30 minutos, $\mathrm{EI}_{30}$, o melhor índice para definir a perda do solo.

A soma dos valores de EI de cada chuva, isoladamente, em determinado período, representa a erosividade da chuva dentro do mesmo período. Já a soma de todos os valores de EI das chuvas caídas em um ano num dado local, dará o valor anual de EI. Assim sendo, o valor da equação é a média dos valores anuais de EI de um período longo de tempo (vinte anos ou mais). $O$ índice de erosão é dado pela equação:

$$
\mathrm{EI}=67,355\left(\mathrm{r}^{2} / \mathrm{p}^{\prime}\right)^{0,85}
$$

onde:

$\mathrm{EI}=$ média mensal do índice de erosão, $\mathrm{MJ} / \mathrm{ha} \cdot \mathrm{mm} / \mathrm{ha}$;

$\mathrm{r}=$ precipitação média mensal, $\mathrm{mm}$;

$\mathrm{p}^{\prime}=$ precipitação média anual, $\mathrm{mm}$. 


\subsubsection{Fator erodibilidade do solo (K)}

De acordo com Hudson (1971) erodibilidade é a capacidade com que o solo se deixa erodir, sendo dependente de variáveis fisicas e mineralógicas como: textura, estrutura, mineralogia e profundidade.

A erodibilidade é expressa pelo fator $\mathbf{K}$, da equação universal de perdas do solo (A = R.K.L.S.C.P.). Sendo assim, K é específico para cada classe de solo. De acordo com suas propriedades fisicas e químicas, cada solo apresenta na sua velocidade de infiltração de água, uma certa resistência do material do solo à dispersão e arrastamento durante as chuvas e ao escorrimento superficial, Wischmeier \& Mannering (1969).

Os valores de K para cada classe de solo, vêm sendo determinados por Bertoni \& Lombardi Neto (1990) através de medição da erosão em talhões experimentais, de condições naturais de medição controlada (chuvas artificiais), ou através de monogramas específicos que consideram características texturais do solo, em vários locais do Estado de São Paulo. Dessa forma, solos com diferentes classes texturais (tamanho de partículas), apresentam diferenças quanto a erodibilidade, que no geral é maior em solos com altos teores de silte e argila decrescendo em solos com maiores teores apenas de argila (Wischmeier et al., 1971; Resende \& Resende, 1983 e Resende \& Almeida, 1985).

A estrutura do solo é influenciada por características químicas e mineralógicas, constituindo-se em um dos parâmetros mais importantes da erodibilidade em solos tropicais.

Para compreender melhor a erodibilidade dos solos, Suares de Castro (1980) considerou o arranjamento das partículas do solo, Resende \& Almeida (1985) enfatizaram a gênese da estrutura, enquanto que para Ayres (1960) são relevantes o tipo e o tamanho ou classe da estrutura.

Para Wischmeier et al. (1971) a estrutura granular pode permitir maior infiltração quando comparada às estruturas maciça, laminar e em blocos, propiciando um menor índice de erodibilidade. 
Os óxidos de ferro (hematita e goethita), e aluminio (gibbsita) agem como cimentantes, e o aumento de seus teores favorece a formação de microestruturas. A presença desses agentes promove uma organização, acarretando em arranjos mais casualizados das partículas, diminuindo em muito a coesão entre si (Resende \& Franzmeier, 1982). A influência desses óxidos permite uma maior resistência à erosão, pois promovem maior combinação das características permeabilidade e coerência.

\subsubsection{Fator comprimento e grau de declive (LS)}

A profundidade do solo está relacionada com a pedogênese (transformação da rocha em solo) e erosão (rapidez com que as camadas são removidas pela água). Essa ação vai depender da topografia, bioclima e da resistência da rocha. $O$ perfil pedogenético se associa ao relevo, o qual tem certas características, como comprimento de rampa ou vertente (L) e declividade (S), que tem grande influência no potencial erosivo (Ranieri, 1996).

Bertoni \& Lombardi Neto (1990) propuseram uma equação para o fator topográfico. Esse fator representa as perdas de solo esperadas para uma unidade de área, em um declive qualquer em relação as perdas de solo, correspondente a uma parcela unitária de $25 \mathrm{~m}$ de comprimento com $9 \%$ de declividade:

$$
\text { LS }=0,00984 \cdot c^{0,63} \cdot d^{1,81}
$$

onde:

LS = Fator topográfico;

$\mathrm{c}=$ Comprimento de rampa $(\mathrm{m})$;

$\mathrm{d}=$ grau de declive $(\%)$.

Segundo Wischmeier \& Smith (1958) existe uma relação entre o comprimento de rampa ou vertente (L) e declividade (S) com característica do solo e da chuva em trabalhos dessa natureza. 
Resende (1992), menciona que, além do declive (S) e comprimento de rampa (L), a forma de relevo é de grande importância na erosão, sendo que a erodibilidade do solo aumenta da côncava para a convexa.

\subsubsection{Fatores uso-manejo do solo (C) e práticas conservacionistas (P)}

O uso e o manejo do solo, podem agravar como amenizar os problemas de erosão. Esses fatores são analisados na equação de perdas do solo pelos fatores C (uso e manejo) e P (práticas conservacionistas). Assim, para uma melhor compreensão desses fatores, deve-se determinar as atuais formas de ocupação e utilização das terras.

Para Stein et al. (1987) o uso de uma gleba pode implicar em vários manejos, o que vai ocasionar várias combinações com diferentes perdas de solo devido a diferentes estágios de desenvolvimento, incidência de fatores climáticos, produtividade de cada solo e ao manejo dos solos cultivados. A interação e influência desses fatores, representam as perdas de solo devidos aos fatores de uso e manejo.

Resende \& Almeida (1985) observaram claramente a eficiência da cobertura vegetal, da cobertura morta e da rotação de cultura, como formas mais eficazes de diminuir os processos erosivos, quando comparados às práticas mecânicas.

As práticas mecânicas podem ser consideradas como conservacionistas. Bertoni \& Lombardi Neto (1990) definem o valor (P) como sendo a relação entre as perdas de solo de um terreno cultivado sob práticas conservacionistas e uma cultura realizada no sentido do declive, "morro abaixo" (Tabela 1).

A partir do estudo de várias características e potencialidades de cada solo, é possível que se possa realizar um uso e manejo, com o máximo de produtividade e o mínimo de erodibilidade. 
Tabela 1 - Valor de $\mathbf{P}$ para algumas práticas conservacionistas

\begin{tabular}{lc}
\hline \multicolumn{1}{c}{ Práticas conservacionistas } & Valor de P \\
\hline Plantio morro abaixo & 1,0 \\
Plantio em contorno & 0,5 \\
Alternância de Capinas + plantio em contorno & 0,4 \\
Cordões de vegetação permanente & 0,2 \\
\hline
\end{tabular}

Fonte: Bertoni \& Lombardi Neto (1990)

\subsection{Tolerância de perdas de solo}

A tolerância de perda de solo, é a quantidade de solo por unidade de área (t/ha) que pode ser perdida por erosão. Reflete a perda máxima de solo possível de se admitir, com um grau de conservação tal, que mantenha uma produção econômica em futuro previsivel com os meios técnicos disponíveis (Bertoni \& Lombardi Neto, 1975).

Segundo Pierce et al. (1984), o conceito de tolerância é considerado "vago" por diversos autores, onde os valores até hoje encontrados têm sido criticamente examinados, revisados ou corrigidos, porém, ainda é necessário o estabelecimento de valores limitantes de perdas de solo.

Apesar dos critérios de tolerância estarem bem estabelecidos, os limites usados ainda não condizem com as condições naturais dos solos tropicais (Sparovek $\&$ jong van Lier, 1993).

Lombardi Neto \& Bertoni (1975) em estudos de vários solos, estabeleceram padrões de tolerância de perdas de solo para o Estado de São Paulo, onde levaram em consideração a profundidade do solo e algumas propriedades fisicas. Os autores salientam a subjetividade na escolha das propriedades dos solos consideradas essenciais, basearamse na profundidade favorável para o desenvolvimento radicular e na relação textural dos horizontes de superficie e subsuperficie. Os valores de tolerância média de perdas de solo variam de 4,5 a 13,2 t/ha.ano para solos com horizonte $B$ textural, 9,6 a $15 \mathrm{t} / \mathrm{ha}$.ano para solos com horizonte B Latossólico e 4 t/ha.ano para os Litólicos. 


\subsection{Sistemas de avaliação de terras}

O planejamento da ocupação das terras é de fundamental importância para a preservação dos recursos naturais. Avaliar as terras é uma importante etapa, pois permite estimar o potencial da mesma e o nível tecnológico para o desenvolvimento da agricultura. A avaliação das terras é uma técnica útil para o planejamento do uso das terras, com a finalidade de evitar a degradação, permitindo escolher a atividade mais adequada para cada classes de solo.

Resumidamente, pode-se utilizar para o planejamento do uso dos solos as seguintes técnicas:

a) Capacidade de uso das terras: a qual estabelece práticas de conservação do solo na propriedade, como curvas de nível, cordão de proteção, terraceamento etc. citados por Bertoni \& Lombardi Neto, 1990;

b) Aptidão agrícola: apresenta-se a nível regional, promovendo diferentes tipos de utilização agrícola;

c) Zoneamento ecológico: implantação de determinados tipos de culturas.

Segundo Assad (1995), os sistemas mais utilizados no Brasil para a avaliação da aptidão agrícola das terras, são os sistemas de Classificação da Classe de Capacidade de Uso da Terra (Lepsch et al., 1991) e o Sistema de Avaliação da Aptidão Agrícola das Terras, na versão realizada por Ramalho et al. (1978).

Para Formaggio et al. (1992), um método ideal para se promover uma adequação do uso da terra, seria um sistema semi automático e não subjetivo, onde a obtenção da aptidão agrícola estaria associada à verificação periódica do uso da terra e a comparação com uso ideal gerado pela aptidão agrícola. Tal sistema seria um poderoso instrumento na conservação dos solos e de planejamento, podendo monitorar e propor as melhores opções para o uso da terra.

Para tanto, vários sistemas vêm sendo desenvolvidos, entre eles o Sistema de Análise Ambiental para Planejamento Agrícola (SAMPA), o qual foi desenvolvido no IGCE-CEAPLA, na UNESP- Rio Claro, por Koffler (1992), que segue os fundamentos 
gerais de trabalhos de levantamento da aptidão agrícola das terras, como descritos por Ramalho et al. (1978) e Oliveira \& Berg (1985), sendo feitas várias adaptações para permitir a automatização do sistema.

Koffler (1996) utilizando o SAMPA para estudo do uso da terra na Bacia do Rio Bauru, conclui que em 1992 ocorria uma grande ociosidade no uso da terra da bacia. As maiores distorções ocorriam em áreas indicadas para culturas de ciclo curto onde predominavam ciclo longo (cana-de-açúcar). As culturas de ciclo longo, as quais invadiam terras preferenciais para outros usos, tinham grande parte da sua área preferencial ocupadas por pastagens e silvicultura e somente as áreas recomendadas para silvicultura estavam sendo em grande parte utilizadas adequadamente.

\subsection{Cronologia do uso da terra}

O sensoriamento remoto, devido a sua rapidez e repetividade de informações, permite a acompanhar e avaliar, de maneira rápida e freqüente, áreas agrícolas (Myers, 1975).

As técnicas de sensoriamento remoto vem se destacando como uma poderosa ferramenta para o estudo de mudanças espaço - temporais do meio físico, através das trocas energéticas entre objetos e o ambiente (Amaral, 1992).

Segundo Crósta (1992) o sensoriamento remoto representa uma das únicas formas viáveis de monitoramento ambiental em escalas locais e globais, dada a sua eficiência, rapidez, periodicidade e visão sinóptica, constituindo-se como uma ferramenta estratégica para o futuro, dada a necessidade de monitorar as mudanças globais que vêm ocorrendo na superficie do planeta.

Donzelli et al. (1992) enfatizam a grande importância de se usar procedimentos de análises multiespectral-multitemporal, na identificação de alvos com caráter dinâmico, como é o caso do uso da terra (cobertura vegetal).

Santos et al. (1988), utilizando imagens TM/LANDSAT com interpretação visual, concluiram que as informações coletadas à partir de três datas distintas, permitiram inferir 
sobre a intensidade de ocupação do solo, obtendo-se inúmeras informações com um custo baixo e curto espaço de tempo.

Alencar et al. (1996) constataram a partir de dados orbitais de épocas distintas 1984 e 1991, um acréscimo nas áreas de floresta secundária, o que mostrou que durante os sete anos de análise a cobertura vegetal dessas áreas está tendendo a uma regeneração.

Segundo Sanchez \& Gerardi (1983) a fotointerpretação é um dos tipos de sensoriamento remoto mais antigos e ainda um dos mais utilizados, devido ao nível de resolução que se pode oferecer, sem que se torne necessário a utilização de sofisticado e oneroso processo de interpretação. Ainda segundo os autores, a fotointerpretação é útil para os mapeamentos de épocas diferentes, o que permite detectar elementos e situações importantes, facilitando tomadas de decisões futuras.

Coelho (1974) estudando interpretação de fotografias aéreas pancromáticas em duas épocas (1962 e 1972), analisou a evolução do uso do solo, em uma área de 1.586 $\mathrm{km}^{2}$, abrangendo 5 municípios da região sudeste do Estado de São Paulo.

Batista (1982) estudou a evolução da vegetação de cerrado através de imagens fotográficas tomadas em três épocas diferentes (1962, 1972 e 1978), onde verificou através de tonalidade e textura, um adensamento da vegetação no período de 1972 e 1978.

Amancio (1986) concluiu que a utilização de fotografias aéreas possibilitou a avaliação da evolução do uso da terra, em uma fazenda próxima ao município de Manduri - SP, durante um periodo de 23 anos correspondente as três épocas analisadas $(1949,1962$ e 1972). Ainda segundo o autor, em 1949 a área era ocupada basicamente por pastagens naturais, cafezais, matas nativas e indícios de culturas temporárias (milho) sem preocupações de práticas conservacionistas. Em 1962 ocorreu um aumento nas áreas de milho e uma maior preocupação com as práticas conservacionistas, com uma redução em área de pastagens, cafezais e matas. Em 1972, o autor, ainda observou um aumento nas áreas de produção de milho e uma diminuição nas práticas conservacionistas.

Mere \& Braga (1988) ao estudarem os impactos causados em torno da barragem de Tucuruí, concluíram que foi de fundamental importância uma análise histórica em 
cinco épocas distintas $(1976,1979,1984,1985$ e 1986), utilizando fotografias aéreas e imagens LANDSAT. Ainda segundo os autores, no "pico da obra" em 1981, ocorreu um aumento explosivo do contingente populacional da cidade de Tucuruí.

Borges et al. (1993) concluíram que o uso de fotografias aéreas para o estudo da evolução e mapeamento do uso da terra no município de Santa Bárbara D'Oeste, proporcionou um maior detalhamento possibilitando a identificação de áreas com culturas anuais e perenes, o que não foi possível com a utilização de imagens orbitais.

Ainda segundo Borges et al. (1993) durante os períodos analisados (1978 à 1991), no município de Santa Bárbara D’Oeste , a área com a cultura de cana-de-açúcar permaneceu a mesma. Observaram ainda que as áreas de mata e pastagem diminuíram, enquanto que as áreas de reflorestamento e urbana aumentaram.

Politano et al. (1983), através do uso de fotografias aéreas, detectaram que a ocupação da cana-de-açúcar no município de Jaboticabal pode estar associada a condições distintas de solo e relevo, além da influência da localização da área em relação à proximidade de usinas de açúcar e álcool. Ainda segundo os autores, problemas fitossanitários ligados a exploração de citrus, bem como os incentivos do governo à expansão da cultura canavieira, provocaram posteriormente mudanças expressivas dos canaviais na região de Monte Alto - SP.

A integração de dados de sensoriamento remoto e dados de solos, através de um sistema de análise georreferenciada, possibilitou detectar as mudanças no uso da terra, em 6.594 ha dos 13.080 ha sob floresta, no município de Ubajara (CE), entre os anos de 1958 e 1985 (Silva et al., 1993). Ainda segundo os autoress, $13 \%$ dos desmatamentos ocorreram no Latossolo Vermelho Amarelo Podzólico distrófico, com alto risco de erosão. 


\subsection{Uso do solo}

As áreas em processo de degradação na Região de Piracicaba, devido a super utilização, concentram-se principalmente em solos com menor profundidade, arenosos e declivosos, onde apesar de aptidão restrita vêm sendo utilizados para o plantio de canade-açúcar (Sparovek \& Lepsch, 1995).

Flores (1995) considera que os solos Podzólicos são mais susceptíveis a erosão e geralmente quando em relevos forte ondulados são mais indicados para reflorestamento e matas, quando em relevo ondulado podem ser utilizados por pastagens e suave ondulado por lavouras. Ainda segundo o autor, os Cambissolos e solos Litólicos, são altamente susceptíveis a erosão e geralmente associados a relevos ondulados e forte ondulado, destinados a áreas de preservação (reflorestamentos e matas), quando em relevo ondulado, dependendo da profundidade desses solos, podem ser usados para cultivos anuais, perenes e pastagens. Os solos Aluviais podem ser usados para culturas anuais, perenes e pastagens e a Terra Roxa Estruturada, com alto potencial não apresenta restrições para seu uso. 


\section{MATERIAL E MÉTODOS}

\subsection{Material}

\subsubsection{Localização da área de estudo}

A Microbacia Hidrográfica do Córrego do Ceveiro (MHC) está situada a $22^{\circ} 40^{\prime} \mathrm{S}$ e $47^{\circ} 47^{\prime} \mathrm{W}$ no Município de Piracicaba (SP), constituindo uma superficie de aproximadamente 2.200 ha (Figura 1), limitada a montante pela Vila de Santana e a jusante pelo Distrito de Artemis e pelo Rio Piracicaba.

\subsubsection{Geologia e Material de Origem}

Segundo o mapa geológico do Estado de São Paulo, (IPT, 1981) a geologia da bacia está representada por rochas relacionadas com a Formação Corumbataí do Grupo Passa Dois, com arenitos da Formação Pirambóia e rochas intrusivas básicas da Formação Serra Geral, ambas pertencentes ao Grupo São Bento (Figura 2).

As rochas da Formação Corumbataí (siltitos, argilitos e folhelhos cinzentos a roxos), dão origem a cerca de $67 \%$ dos solos da bacia, os quais ocorrem principalmente às margens do Ceveiro e ao lado esquerdo da bacia (sentido de observação montante à jusante). Já nos topos, à direita da bacia, encontram-se com mais freqüência os solos originados da formação Pirambóia, que se caracteriza por uma sucessão de camadas de arenitos. A formação Serra Geral, constituída por intrusões básicas, ocorre com maior intensidade na cabeceira da bacia, recobrindo a formação Pirambóia. 
A interface das Formações Pirambóia e Corumbataí é nítida devido a presença de bancos delgados de rochas de sílex, típicos da formação Corumbataí, aflorando no terreno em cotas definidas.

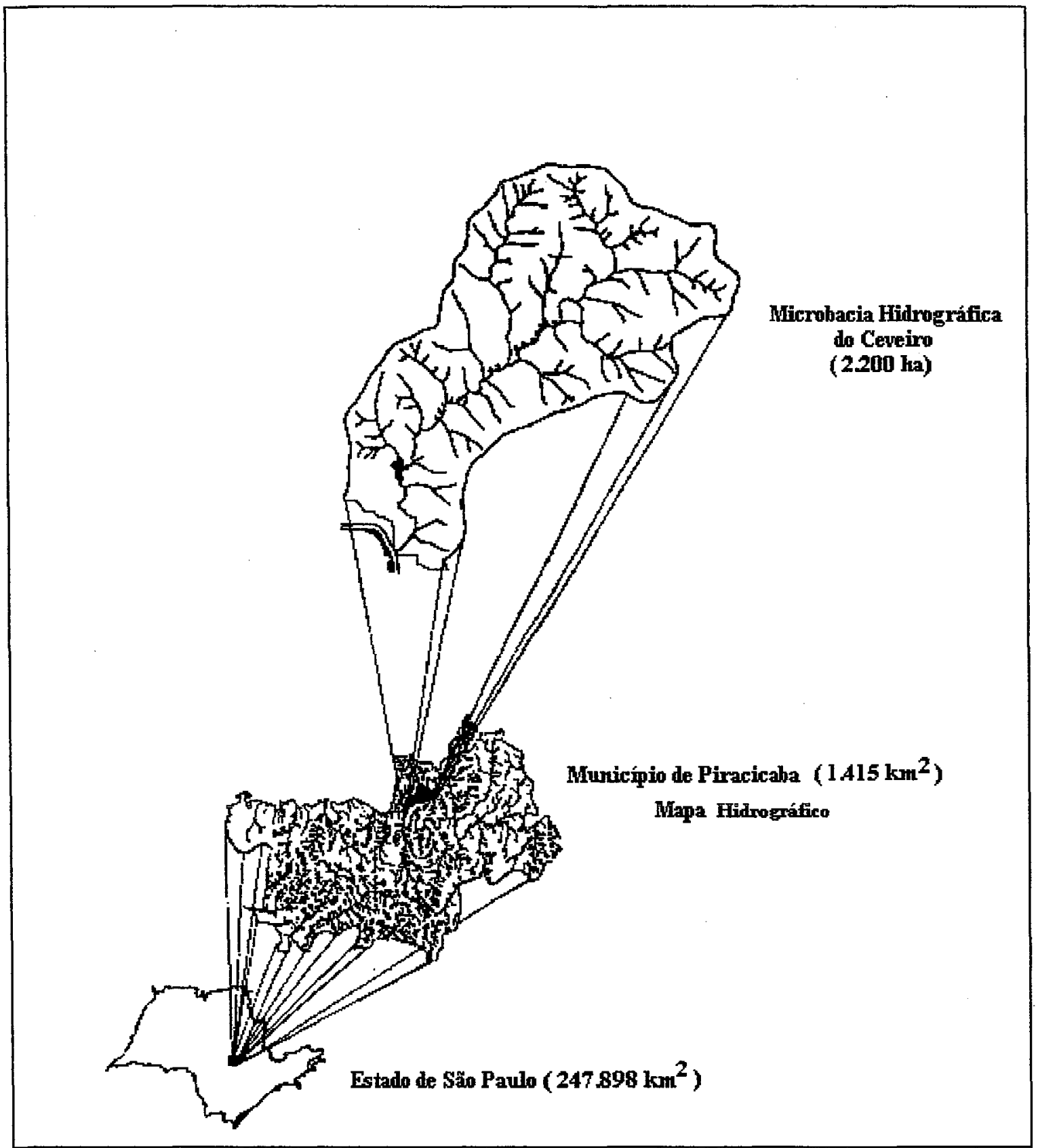

Figura 1 - Localização da Microbacia Hidrográfica do Córrego do Ceveiro no Município de Piracicaba-SP. Fonte: Sparovek, et al. (1991). 


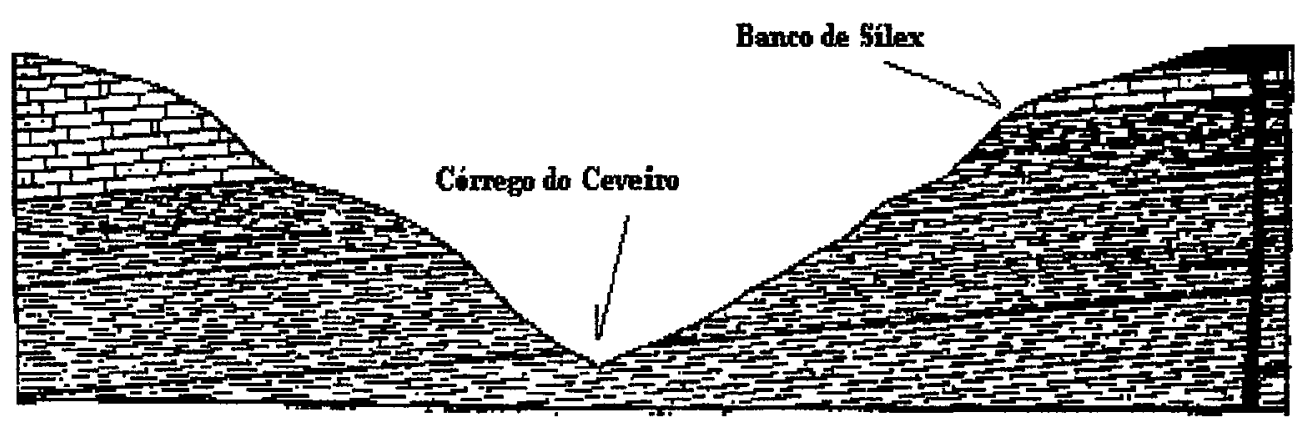

- Intrusinas Bisicas - Formoção Serrz - Geral

Arenitos de Granulação Média - Fina - Formacäo Piraubóa

Siltitos, Argilitos e Folhelltos Cinzentos a Ron aciux. e Anarelo - Foramaçăn Corumbataí

Figura 2 - Corte transversal na Microbacia Hidrográfica do Córrego do Ceveiro, mostrando a disposição das Formações geológicas. Fonte: Sparovek et al. (1991).

\subsubsection{Solos da área de estudo}

No levantamento pedológico realizado por Sparovek et al. (1991), a área em estudo apresenta sete classes de solo ( Podzólicos Vermelhos Amarelos, Terra Roxa Estruturada, Terra Roxa Estruturada Podzólica, Podzólico Vermelho Escuro, Cambissolos, Solos Hidromórficos e Solos Aluviais), os quais são representados por 30 unidades de mapeamento. No presente trabalho foi realizado um reagrupamento dos solos da área, a fim de facilitar o cruzamento dos dados e a interpretação dos resultados, pois muitas dessas classes apresentam manejo semelhantes.

Os solos foram reagrupados em seis grupos: (a) Podzólicos PV, (b) Podzólicos rasos PV raso, (c) Terra Roxa Estruturada TE, Terra Roxa Estruturada Podzólica TEP e 
Podzólico Vermelho Escuro PE, (d) Litólicos Li, (e) Cambissolos Cb, (f) Associação Hidromórficos e Aluviais, $\mathrm{H}+\mathrm{Al}$ (Figura 3).

A descrição de cada classe de solo, em cada grupamento pode ser observada a seguir:

(a) Solos Podzólicos

- PV1 = Podzólico Vermelho Amarelo, álico, Tb, A moderado ou A chernozêmico, textura arenosa/média

- $\mathrm{PV} 2$ = Podzólico Vermelho Amarelo, eutrófico, Ta, A moderado, textura arenosa/média

- PV3 = Podzólico Vermelho Amarelo, álico $\mathrm{Ta}$ ou $\mathrm{Tb}$, $\mathrm{A}$ moderado, textura arenosa/média

- PV4 = Podzólico Vermelho Amarelo, eutrófico, Tb, A moderado, textura arenosa/média

- PV5 = Podzólico Vermelho Amarelo, eutrófico, Tb, $\mathrm{A}$ moderado, textura média/argilosa

- PV6 = Podzólico Vermelho Amarelo, distrófico, Ta, A moderado, textura média/argilosa

- PV7 = Podzólico Vermelho Amarelo, álico, Tb, A moderado, textura média/argilosa

- PV8 = Podzólico Vermelho Amarelo, eutrófico, Ta ou Tb, A moderado (arênico), textura arenosa/argilosa

(b) Solos Podzólicos rasos

- PV1 raso $=$ Podzólico Vermelho Amarelo, distrófico, $\mathrm{Tb}, \mathrm{A}$ moderado ou chernozêmico, textura arenosa/média, fase pouco profunda

- PV2 raso = Podzólico Vermelho Amarelo, álico, Ta, A moderado, textura arenosa/média fase pouco profunda 
- PV3 raso = Podzólico Vermelho Amarelo, álico $\mathrm{Ta}$ ou $\mathrm{Tb}, \mathrm{A}$ moderado, textura arenosa/média fase pouco profunda

- PV4 raso $=$ Podzólico Vermelho Amarelo, eutrófico, Tb, A moderado, textura arenosa/média fase pouco profunda

- PV5 raso $=$ Podzólico Vermelho Amarelo, eutrófico, Tb, A moderado, textura média/argilosa fase pouco profunda

- PV6 raso $=$ Podzólico Vermelho Amarelo, distrófico, Ta, A moderado, textura média/argilosa fase pouco profunda

- PV7 raso = Podzólico Vermelho Amarelo, eutrófico, Tb, A moderado, textura média/argilosa fase pouco profunda

- PV8 raso = Podzólico Vermelho Amarelo, eutrófico, Ta ou Tb, A moderado, textura arenosa/argilosa fase pouco profunda

(c) Terra Roxa Estruturada, Terra Roxa Estruturada Podzólica e Podzólico Vermelho Escuro

- $\mathrm{PE}=$ Grupamento indiscriminado de Podzólico Vermelho Escuro, textura argilosa ou argilosa/muito argilosa com ou sem cascalho (Unidade Campestre)

- $\mathrm{TE}=$ Terra Roxa Estruturada, eutrófica, A moderado, textura muito argilosa (Unidade Estruturada)

- TEP = Terra Roxa Estruturada Podzólica, eutrófica, Tb, A moderado, textura média/argilosa (Unidade Santana)

(d) Solos Litólicos

- Li 1 = Solo Litólico, eutrófico, $\mathrm{Ta}$ ou $\mathrm{Tb}, \mathrm{A}$ moderado ou chernozêmico, textura média, substrato siltitos da Formação Corumbataí

- Li 2 = Solo Litólico, distróficos, Ta, A moderado, textura média, substrato siltitos da For. Corumbataí 
- Li 3 = Solo Litólico, eutrófico, $\mathrm{Ta}$ ou $\mathrm{Tb}, \mathrm{A}$ moderado ou chernozêmico, textura argilosa, substrato folhelho da Formação Corumbataí

- $\mathrm{Li} 4$ = Solo Litólico, álico, Ta, A moderado, textura argilosa, substrato folhelho da Formação Corumbataí

- Li 5 = Solo Litólico, distrófico, Tb, A moderado, textura média, substrato arenitos da Formação. Pirambóia

- $\mathrm{Li} 6=$ Complexo Li3 $+\mathrm{Cb} 2$

- $\mathrm{Li} 7=$ Complexo $\mathrm{TEpp}+\mathrm{Cb} 5+\mathrm{Li} 7$

(e) Cambissolos

- $\mathrm{Cb} 1$ = Cambissolo, eutrófico, Ta ou Tb, A moderado, textura média

- $\mathrm{Cb} 2$ = Cambissolo, eutrófico ou distrófico, $\mathrm{Ta}$ ou Tb, A moderado, textura argilosa.

- $\mathrm{Cb} 3$ = Cambissolo, álico, Ta, A moderado, textura média.

- $\mathrm{Cb} 4$ = Cambissolo, eutrófico, Ta, A moderado, textura média

(f) Solos Hidromórficos e Aluviais

$\mathrm{Al}=$ Grupamento indiscriminado de solos aluviais

Hi 1 = Solo Hidromórfico, álico, Ta, A moderado, textura arenosa/média

Hi 2 = Solo Hidromórfico, eutrófico, Tb, A moderado, textura média/argilosa

Os Solos Litólicos e Podzólicos ocorrem na maior parte da área. Os dados físicos e químicos para todas as classes de solo encontram-se na Tabela $2 \mathrm{a}$ e $2 \mathrm{~b}$. Com relação aos dados de profundidade de cada classe de solo, este e comum a todos, as tradagens foram efetuadas de $0-20 \mathrm{~cm}$ para o horizonte A e $60-80 \mathrm{~cm}$ para o horizonte $\mathrm{B}$ ou $\mathrm{C}$. 


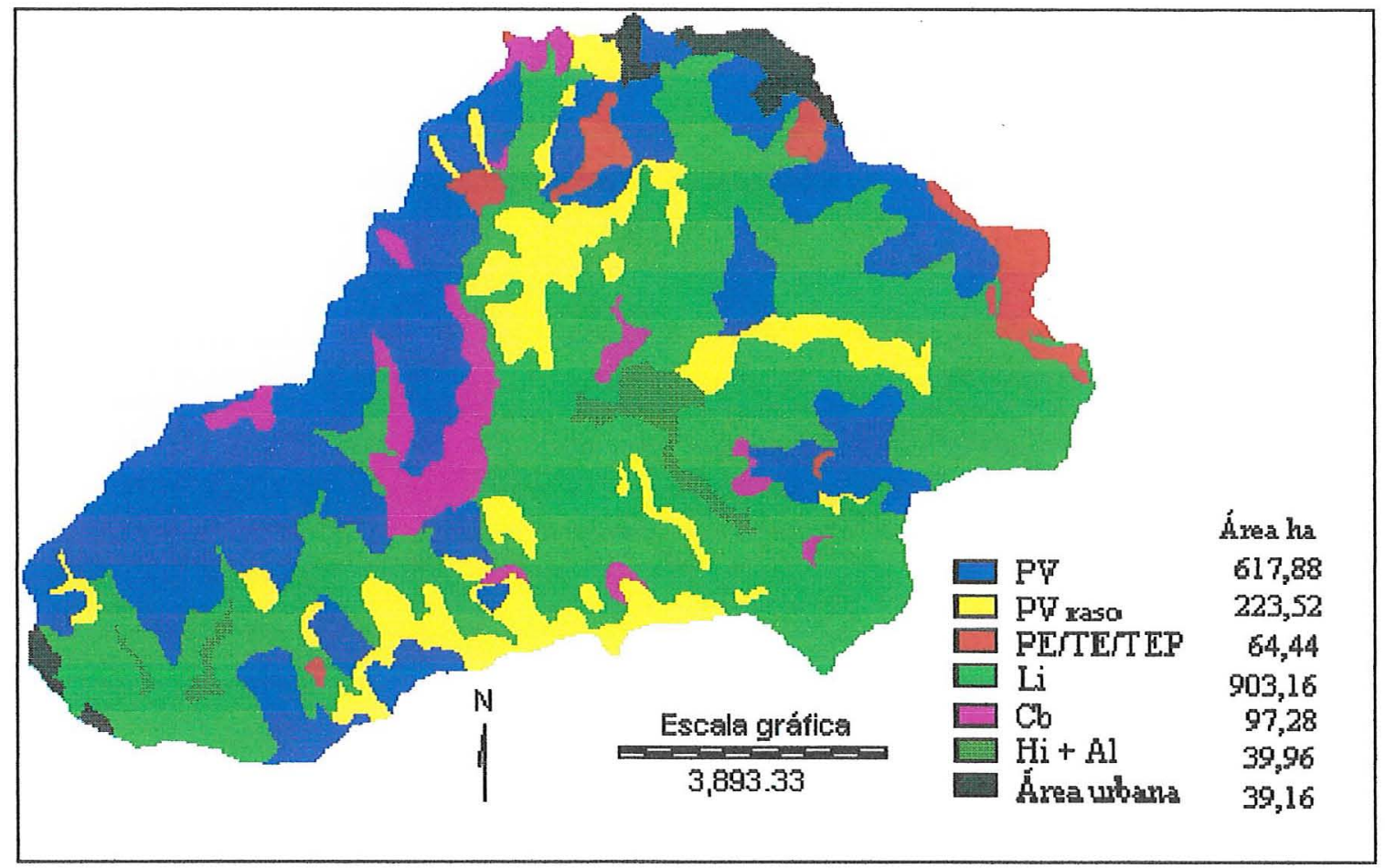

Figura 3 - Mapa pedológico reagrupado da área de estudo.

Fonte: Adaptado de Sparovek et al. (1991).

Tabela 2a - Resultados da análise química das unidades de mapeamento da área de estudo.

\begin{tabular}{|c|c|c|c|c|c|c|c|c|c|c|c|c|c|c|c|}
\hline \multirow{2}{*}{$\begin{array}{c}\text { Solo } \\
\text { Sigla }\end{array}$} & \multirow{2}{*}{$\begin{array}{l}\text { Hori- } \\
\text { zonte }\end{array}$} & \multicolumn{3}{|c|}{$\mathrm{pH}$} & \multirow{2}{*}{$\begin{array}{l}\text { MO } \\
\text { gkg }^{-1}\end{array}$} & \multirow{2}{*}{$\begin{array}{c}\mathrm{P} \\
\mathrm{mg} / \mathrm{kg}\end{array}$} & $\mathrm{K}$ & \multirow{2}{*}{$\mathrm{Ca}$} & \multirow{2}{*}{$\mathrm{Mg}$} & \multirow{2}{*}{$\begin{array}{c}\mathrm{Al} \\
\mathrm{mmol}_{\mathrm{c}} \mathrm{dm}\end{array}$} & \multirow{2}{*}{$\begin{array}{l}\mathrm{H}+\mathrm{Al} \\
\mathrm{n}^{-3}\end{array}$} & \multirow[t]{2}{*}{$\mathrm{S}$} & \multirow[t]{2}{*}{$\mathrm{T}$} & \multirow{2}{*}{\multicolumn{2}{|c|}{$\begin{array}{c}\mathrm{V} \% \\
\%\end{array}$}} \\
\hline & & $\mathrm{H}_{2} \mathrm{O}$ & $\mathrm{KCL}$ & $\mathrm{CaCl}_{2}$ & & & 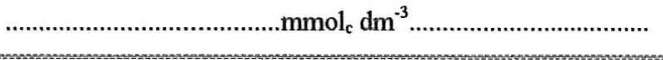 & & & & & & & & \\
\hline \multirow[t]{2}{*}{ PV1 } & A & 5,0 & 4,2 & 4,4 & 13,2 & 25,8 & 1,7 & 9,6 & 2,5 & 8,8 & 17,4 & 14,0 & 31,4 & 43,2 & 24,6 \\
\hline & B & 4,5 & 3,7 & 3,9 & 10,0 & 2,0 & 1,9 & 16,4 & 4,7 & 28,4 & 45,8 & 28,0 & 68,9 & 32,5 & 55,5 \\
\hline \multirow[t]{2}{*}{ PV2 } & A & 4,4 & 3,9 & 3,9 & 12,2 & 2,6 & 1,7 & 8,3 & 8,8 & 13,0 & 32,2 & 12,9 & 45,1 & 26,4 & 55,4 \\
\hline & B & 4,8 & 3,6 & 3,6 & 9,0 & 1,4 & 1,2 & 12,0 & 5,9 & 53,2 & 146,8 & 19,0 & 166,0 & 15,9 & 16,9 \\
\hline \multirow[t]{2}{*}{ PV3 } & A & 5,4 & 4,8 & 4,8 & 12,4 & 39,0 & 2,5 & 17,6 & 4,9 & 1,8 & 13,2 & 25,3 & 38,5 & 61,4 & 10,4 \\
\hline & B & 4,5 & 3,8 & 3,0 & 10,2 & 3,0 & 1,6 & 11,7 & 5,9 & 50,8 & 102,2 & 18,5 & 120,8 & 18,6 & 60,9 \\
\hline \multirow[t]{2}{*}{ PV4 } & A & 5,7 & 5,1 & 5,8 & 12,0 & 4,0 & 1,3 & 15,4 & 3,3 & 0,8 & 7,0 & 20,0 & 27,0 & 74,0 & 4,0 \\
\hline & B & 5,4 & 4,6 & 4,9 & 9,0 & 2,0 & 1,0 & 27,3 & 13,5 & 2,2 & 15,0 & 12,0 & 37,0 & 74,0 & 5,0 \\
\hline \multirow[t]{2}{*}{ PV5 } & A & 3,5 & 4,2 & 4,0 & 17,5 & 10,0 & 3,0 & 20,2 & 5,4 & 2,6 & 26,8 & 20,5 & 54,7 & 52,5 & 10,9 \\
\hline & B & 5,4 & 4,8 & 4,0 & 11,7 & 4,3 & 3,0 & 34,5 & 6,5 & 4,3 & 29,3 & 43,9 & 72,9 & 60,9 & 7,3 \\
\hline \multirow[t]{2}{*}{ PV6 } & A & 5,0 & 4,4 & 4,4 & 17,0 & 35,0 & 3,0 & 25,3 & 6,5 & 6,0 & 32,0 & 34,7 & 66,7 & 47,3 & 21,8 \\
\hline & B & 4,0 & 3,5 & 3,5 & 10,0 & 4,7 & 1,9 & 18,1 & 5,1 & 16,9 & 204,8 & 20,1 & 124,5 & 14,2 & 34,6 \\
\hline \multirow[t]{2}{*}{ PV7 } & A & 4,7 & 4,1 & 4,2 & 20,2 & 9,8 & 1,8 & 23,1 & 5,6 & 11,4 & 51,6 & 30,5 & 82,1 & 39,3 & 26,1 \\
\hline & B & 4,6 & 3,7 & 3,7 & 13,6 & 1,4 & 2,4 & 19,3 & 11,2 & 41,2 & 157,6 & 38,1 & 190,7 & 52,4 & 58,1 \\
\hline \multirow[t]{2}{*}{ PV8 } & A & 5,8 & 4,9 & 5,2 & 15,7 & 10,6 & 0,1 & 59,9 & 8,9 & 0,9 & 18,3 & 71,9 & 90,3 & 66,4 & 3,4 \\
\hline & B & 6,5 & 5,5 & 5,5 & 12,3 & 12,0 & 1,7 & 81,0 & 13,0 & 9,0 & 19,7 & 95,7 & 115,4 & 78,8 & 1,3 \\
\hline \multirow[t]{2}{*}{$\mathrm{PE}$} & A & 5,7 & 4,8 & 5,1 & 24,3 & 60,3 & 2,7 & 41,6 & 7,1 & 1,5 & 29,3 & 51,1 & 80,5 & 57,8 & 3,3 \\
\hline & B & 6,0 & 5,3 & 3,7 & 15,0 & 4,8 & 0,6 & 37,1 & 9,4 & 1,0 & 19,0 & 47,2 & 66,2 & 71,2 & 2,1 \\
\hline
\end{tabular}


Tabela $2 \mathrm{a}$ - Resultados da análise química das unidades de mapeamento da área de estudo (continuação)

\begin{tabular}{|c|c|c|c|c|c|c|c|c|c|c|c|c|c|c|c|}
\hline \multirow{2}{*}{$\begin{array}{l}\text { Solo } \\
\text { Sigla }\end{array}$} & \multirow{2}{*}{$\begin{array}{l}\text { Hori- } \\
\text { zonte }\end{array}$} & \multicolumn{3}{|c|}{$\mathrm{pH}$} & \multirow{2}{*}{$\begin{array}{l}\text { MO } \\
\text { gkg }^{-1}\end{array}$} & \multirow{2}{*}{$\begin{array}{c}\mathrm{P} \\
\mathrm{mg} / \mathrm{kg}\end{array}$} & $\bar{K}$ & \multirow[t]{2}{*}{$\mathrm{Ca}$} & \multirow[t]{2}{*}{$\mathrm{Mg}$} & \multirow{2}{*}{$\begin{array}{l}\text { Al } \\
\text { mol }_{c} \mathbf{~ d m}\end{array}$} & \multirow{2}{*}{$\begin{array}{l}\mathrm{H}+\mathrm{Al} \\
\mathrm{a}^{-3}\end{array}$} & \multirow[t]{2}{*}{$\mathrm{s}$} & \multirow{2}{*}{$\mathrm{T}$} & $\mathrm{V} \%$ & \multirow[t]{2}{*}{$\mathrm{m} \%$} \\
\hline & & $\mathrm{H}_{2} \mathrm{O}$ & KCL & $\mathrm{CaCl}_{2}$ & & & $\cdots$ & & & & & & & $\%$ & \\
\hline \multirow[t]{2}{*}{$\overline{\mathrm{TE}}$} & $\bar{A}$ & 6,2 & 5,5 & 5,6 & 31,2 & 32,6 & 6,4 & 76,2 & 32,5 & 1,4 & 32,4 & 115,1 & 147,5 & 71,9 & 1,8 \\
\hline & B & 6,3 & 5,6 & 5,6 & 20,0 & 24,4 & 3,5 & 50,1 & 16,5 & 1,1 & 57,8 & 70,1 & 127,9 & 63,7 & 1,5 \\
\hline \multirow[t]{2}{*}{ TEP } & A & 5,6 & 5,1 & 0,1 & 20,5 & 8,8 & 1,8 & 41,7 & 6,3 & 1,3 & 26,5 & 51,7 & 28,2 & 34,9 & 1,9 \\
\hline & B & 6,0 & 5,3 & 5,5 & 18,5 & 17,8 & 5,6 & 40,1 & 2,8 & 1,6 & 23,0 & 69,3 & 92,8 & 49,0 & 8,2 \\
\hline \multirow[t]{2}{*}{$\mathrm{Cb} 2$} & $A$ & 5,4 & 4,7 & 5,1 & 23,4 & 19,7 & 2,9 & 54,0 & 16,8 & 4,5 & 26,9 & 74,5 & 101,5 & 75,9 & 6,9 \\
\hline & B & 5,2 & 4,2 & 4,6 & 15,3 & 6,6 & 1,9 & 48,1 & 15,4 & 10,7 & 47,1 & 60,4 & 107,5 & 57,4 & 30,1 \\
\hline \multirow[t]{2}{*}{$\mathrm{Cb} 3$} & A & 7,8 & 6,8 & 7,2 & 36,0 & 72,0 & 7,3 & 39,2 & 11,3 & 1,4 & 10,0 & 148,0 & 158,0 & 94,0 & 1,0 \\
\hline & B & 5,1 & 3,8 & 3,7 & 8,0 & 1,0 & 4,8 & 12,7 & 9,1 & 65,8 & 228,0 & 26,0 & 231,0 & 10,0 & 78,0 \\
\hline \multirow[t]{2}{*}{$\mathrm{Cb} 4$} & A & 4,8 & 4,0 & 4,3 & 15,0 & 2,0 & 1,6 & 28,7 & 3,1 & 7,8 & 31,0 & 33,0 & 34,0 & 52,0 & 15,0 \\
\hline & B & 5,3 & 4,4 & 4,7 & 11,0 & 4,0 & 1,5 & 48,8 & 4,5 & 2,8 & 10,0 & 50,0 & 68,0 & 73,0 & 4,0 \\
\hline \multirow[t]{2}{*}{$\mathrm{Li} 1$} & A & 5,4 & 4,7 & 4,9 & 33,6 & 33,2 & 4,4 & 60,6 & 14,9 & 4,7 & 37,2 & 77,9 & 117,1 & 66,1 & 7,1 \\
\hline & C & 5,3 & 4,5 & 4,7 & 16,7 & 27,4 & 4,0 & 66,0 & 14,5 & 0,9 & 45,7 & 36,6 & 32,4 & 67,5 & 9,3 \\
\hline \multirow[t]{2}{*}{$\operatorname{Li} 2$} & A & 5,2 & 4,6 & 5,0 & 20,0 & 30,5 & 2,6 & 68,3 & 29,9 & 12,1 & 52,0 & 101,8 & 153,8 & 64,2 & 15,4 \\
\hline & $\mathrm{C}$ & 4,4 & 3,5 & 3,6 & 17,0 & 5,0 & 2,4 & 35,3 & 12,2 & 61,6 & 276,0 & 49,8 & 325,8 & 16,7 & 35,9 \\
\hline \multirow[t]{2}{*}{$\mathrm{Li} 3$} & A & 5,5 & 4,7 & 5,0 & 25,4 & 68,3 & 6,3 & 59,7 & 14,6 & 5,0 & 39,5 & 80,5 & 120,0 & 63,0 & 9,3 \\
\hline & $\mathrm{C}$ & 6,0 & 4,9 & 5,2 & 14,7 & 2,4 & 2,7 & 94,6 & 19,2 & 5,3 & 34,4 & 117,4 & 151,8 & 74,8 & 5,2 \\
\hline \multirow[t]{2}{*}{ Li 4} & A & 4,9 & 4,2 & 4,8 & 25,5 & 51,0 & 3,2 & 47,5 & 13,3 & 18,8 & 60,5 & 60,9 & 150,2 & 52,2 & 10,5 \\
\hline & C & 4,1 & 3,6 & 3,7 & 13,0 & 3,8 & 2,6 & 21,2 & 11,2 & 50,4 & 249,5 & 35,0 & 204,5 & 22,6 & 55,3 \\
\hline Li 5 & A & 5,0 & 4,3 & 4,6 & 28,0 & 0,7 & 2,8 & 27,7 & 9,6 & 6,8 & 41,0 & 41,1 & 82,1 & 47,8 & 14,3 \\
\hline & $\mathrm{C}$ & 4,7 & 3,6 & 3,9 & 12,0 & 4,0 & 2,5 & 31,9 & 10,7 & 31,2 & 121,0 & 48,0 & 166,0 & 27,0 & 11,0 \\
\hline $\mathrm{Li} 6$ & A & 5,9 & 5,3 & 5,4 & 3,5 & 30,0 & 36,7 & 60,7 & 16,7 & 0,9 & 23,5 & 92,0 & 115,5 & 77,1 & 1,3 \\
\hline & C & 5,5 & 4,5 & 5,0 & 17,0 & 4,5 & 4,0 & 102,1 & 21,7 & 4,8 & 32,3 & 127,8 & 160,3 & 79,7 & 3,4 \\
\hline $\mathrm{Li} 7$ & A & 5,8 & 5,3 & 4,9 & 32,0 & 29,0 & 8,6 & 82,8 & 29,9 & 1,0 & 13,0 & 122,0 & 35,0 & 90,0 & 1,0 \\
\hline $\mathrm{Hi} 1$ & A & 4,4 & 3,9 & 4,1 & 17,0 & 19,0 & 2,2 & 15,6 & 3,6 & 13,8 & 51,0 & 21,3 & 72,3 & 30,5 & 39,2 \\
\hline & $\mathrm{Bg}$ & 4,4 & 3,3 & 3,5 & 8,0 & 2,0 & 2,3 & 21,6 & 7,0 & 30,4 & 201,5 & 30,9 & 232,4 & 13,2 & 63,3 \\
\hline $\mathrm{Hi} 2$ & A & 4,6 & 3,0 & 4,1 & 15,0 & 18,0 & 1,0 & 11,1 & 5,9 & 9,2 & 42,0 & 19,0 & 61,0 & 31,0 & 33,0 \\
\hline & $\mathrm{Bg}$ & 5,5 & 4,1 & 4,4 & 7,0 & 5,0 & 1,6 & 31,7 & 14,3 & 5,4 & 24,0 & 40,0 & 82,0 & 50,0 & 10,0 \\
\hline PV1 raso & A & 4,9 & 4,1 & 4,0 & 18,0 & 2,0 & 0,7 & 16,0 & 2,2 & 5,4 & 28,0 & 19,0 & 47,0 & 40,0 & 22,0 \\
\hline & $\mathbf{B}$ & 4,0 & 4,3 & 3,8 & 14,0 & 3,0 & 0,4 & 6,9 & 1,7 & 7,0 & 34,0 & 9,0 & 43,0 & 21,0 & 46,0 \\
\hline PV4 raso & A & 4,5 & 3,8 & 3,9 & 10,0 & 4,0 & 1,0 & 6,8 & 1,7 & 8,4 & 25,0 & 10,0 & 35,0 & 28,0 & 47,0 \\
\hline & B & 4,7 & 3,9 & 4,2 & 7,0 & 1,0 & 1,9 & 24,3 & 11,8 & 9,4 & 31,0 & 30,0 & 69,0 & 55,0 & 20,0 \\
\hline PV5 raso & A & 5,2 & 4,6 & 4,7 & 19,3 & 19,8 & 2,7 & 31,3 & 7,4 & 4,5 & 27,9 & 41,6 & 69,5 & 37,1 & 11,7 \\
\hline & B & 5,2 & 4,2 & 4,4 & 19,1 & 5,4 & 8,3 & 40,3 & 12,5 & 14,9 & 61,6 & 51,5 & 116,6 & 50,3 & 22,0 \\
\hline PV6 raso & A & 4,9 & 4,4 & 4,6 & 16,0 & 22,0 & 1,3 & 46,9 & 5,0 & 7,2 & 34,0 & 54,0 & 38,0 & 61,0 & 12,0 \\
\hline & B & 4,8 & 3,7 & 4,0 & 13,0 & 2,0 & 1,9 & 42,7 & 7,4 & 34,8 & 98,0 & 32,0 & 150,0 & 36,0 & 38,0 \\
\hline PV7 raso & A & 4,5 & 3,8 & 3,9 & 18,0 & 9,0 & 2,4 & 8,5 & 3,0 & 13,4 & 42,0 & 13,0 & 55,0 & 21,0 & 47,0 \\
\hline & B & 5,2 & 4,1 & 4,2 & 15,0 & 8,0 & 1,5 & 34,4 & 31,4 & 17,4 & 10,2 & 54,0 & 48,0 & 54,0 & 27,0 \\
\hline PV8 raso & $\mathrm{A}$ & 3,2 & 4,5 & 4,9 & 8,0 & 5,0 & 0,4 & 9,4 & 0,1 & 0,8 & 12,0 & 10,0 & 32,0 & 45,0 & 7,0 \\
\hline & B & 6,1 & 5,3 & 5,3 & 7,0 & 4,0 & 0,7 & 36,7 & 4,7 & 0,8 & 15,0 & 42,0 & 57,0 & 74,0 & 2,0 \\
\hline
\end{tabular}


Tabela $2 \mathrm{~b}$ - Resultados da análise granulométrica das unidades de mapeamento da área de estudo.

\begin{tabular}{|c|c|c|c|c|c|c|c|}
\hline \multirow[t]{2}{*}{ Solo/Sigla } & \multirow[t]{2}{*}{ Horizonte } & Argila & Silte & Areia (Total) & Areia Grossa & Areia Média & Areia Fina \\
\hline & & \multicolumn{6}{|c|}{$\mathrm{gkg}^{-1}$} \\
\hline \multirow[t]{2}{*}{ PV1 } & $\bar{A}$ & 70 & 96 & 834 & 8 & 54 & 772 \\
\hline & B & 280 & 94 & 626 & 4 & 42 & 580 \\
\hline \multirow[t]{2}{*}{ PV2 } & A & 102 & 126 & 772 & 20 & 62 & 690 \\
\hline & B & 298 & 120 & 620 & 14 & 42 & 564 \\
\hline \multirow[t]{2}{*}{ PV3 } & A & 50 & 96 & 854 & 10 & 104 & 740 \\
\hline & B & 228 & 88 & 688 & 6 & 88 & 594 \\
\hline \multirow[t]{2}{*}{ PV4 } & A & 50 & 100 & 850 & 10 & 170 & 670 \\
\hline & B & 340 & 70 & 590 & 30 & 170 & 390 \\
\hline \multirow[t]{2}{*}{ PV5 } & A & 160 & 185 & 655 & 13,3 & 36,7 & 605 \\
\hline & B & 436,7 & 135 & 426,3 & 10,8 & 17,5 & 400 \\
\hline \multirow[t]{2}{*}{ PV6 } & A & 293,3 & 396,7 & 320 & 20 & 36,7 & 263,3 \\
\hline & B & 523,3 & 286,7 & 190 & 11,7 & 18,3 & 160 \\
\hline \multirow[t]{2}{*}{ PV7 } & A & 232 & 256 & 512 & 8 & 16 & 488 \\
\hline & B & 638 & 161 & 196 & 1 & 11 & 184 \\
\hline \multirow[t]{2}{*}{ PV8 } & A & 113,3 & 140 & 746,7 & 13,3 & 23,3 & 710 \\
\hline & B & 373,3 & 126,7 & 500 & 13,3 & 10 & 476,7 \\
\hline \multirow[t]{2}{*}{$\mathrm{PE}$} & A & 326,7 & 203,3 & 470 & 10 & 23,3 & 436,7 \\
\hline & B & 526,7 & 160 & 313 & 6,7 & 13,3 & 293,3 \\
\hline \multirow[t]{2}{*}{$\mathrm{TE}$} & A & 508 & 206 & 286 & 90 & 26 & 168 \\
\hline & B & 692 & 164 & 144 & 44 & 12 & 88 \\
\hline \multirow[t]{2}{*}{ TEP } & A & 330 & 277,5 & 397,5 & 212,5 & 30 & 155 \\
\hline & B & 597,5 & 190 & 212,5 & 145 & 11,3 & 56,3 \\
\hline \multirow[t]{2}{*}{$\mathrm{Cb} 2$} & A & 322,2 & 357,8 & 320 & 4,4 & 24,4 & 271,1 \\
\hline & B & 375,6 & 395,6 & 230 & 23,9 & 27,2 & 176,9 \\
\hline \multirow[t]{2}{*}{$\mathrm{Cb} 3$} & A & 70 & 210 & 720 & 10 & 60 & 650 \\
\hline & B & 130 & 220 & 650 & 10 & 40 & 600 \\
\hline \multirow[t]{2}{*}{$\mathrm{Cb} 4$} & A & 140 & 220 & 640 & 10 & 30 & 600 \\
\hline & B & 130 & 250 & 620 & 0 & 10 & 610 \\
\hline \multirow[t]{2}{*}{ Li 1} & A & 327,7 & 406 & 267,7 & 31 & 27 & 208,3 \\
\hline & $\mathrm{c}$ & 382,2 & 400 & 207,2 & 27 & 27,2 & 152,2 \\
\hline \multirow[t]{2}{*}{$\mathrm{Li} 2$} & A & 230 & 500 & 270 & 40 & 30 & 200 \\
\hline & C & 315 & 430 & 235 & 175 & 35 & 45 \\
\hline \multirow[t]{2}{*}{$\mathrm{Li} 3$} & A & 495 & 407,5 & $18,7,5$ & 40 & 30 & 117,5 \\
\hline & c & 421,6 & 356 & 196 & 62 & 48 & 86 \\
\hline \multirow[t]{2}{*}{$\operatorname{Li} 4$} & A & 377,5 & 342,5 & 26,0 & 12,5 & 17,5 & 230 \\
\hline & C & 537,5 & 297,5 & 165 & 5 & 7,5 & 152,5 \\
\hline \multirow[t]{2}{*}{ Li 5} & A & 336,7 & 490 & 173,3 & 23,3 & 23,3 & 126,7 \\
\hline & C & 420 & 470 & 110 & 10 & 20 & 80 \\
\hline
\end{tabular}


Tabela $2 \mathrm{~b}$ - Resultados da análise granulométrica das unidades de mapeamento da área de estudo (Continuação).

\begin{tabular}{|c|c|c|c|c|c|c|c|}
\hline \multirow[t]{2}{*}{ Solo/sigla } & \multirow[t]{2}{*}{ Horizonte } & Argila & Silte & Areia (Total) & Areia Grossa & Areia Média & Areia Fina \\
\hline & & \multicolumn{6}{|c|}{$\mathrm{gkg}^{-1}$} \\
\hline \multirow[t]{2}{*}{ Li 6} & $\bar{A}$ & 425 & 435 & 140 & 20 & 20 & 100 \\
\hline & $\mathrm{C}$ & 485 & 320 & 195 & 55 & 35 & 105 \\
\hline Li 7 & A & 470 & 170 & 360 & 20 & 70 & 270 \\
\hline \multirow[t]{2}{*}{ Hi-1 } & A & 200 & 455 & 345 & 20 & 25 & 300 \\
\hline & $\mathrm{Bg}$ & 515 & 355 & 130 & 7,5 & 12,5 & 110 \\
\hline \multirow[t]{2}{*}{ Hi-2 } & A & 170 & 470 & 360 & 10 & 10 & 340 \\
\hline & $\mathrm{Bg}$ & 380 & 360 & 260 & 10 & 40 & 210 \\
\hline \multirow[t]{2}{*}{ PV1 raso } & A & 130 & 110 & 760 & 20 & 150 & 590 \\
\hline & B & 110 & 110 & 780 & 30 & 170 & 590 \\
\hline \multirow[t]{2}{*}{ PV4 raso } & A & 110 & 90 & 800 & 10 & 30 & 760 \\
\hline & B & 320 & 100 & 590 & 0 & 10 & 570 \\
\hline \multirow[t]{2}{*}{ PV5 raso } & A & 236,7 & 296,7 & 466,7 & 60 & 17,8 & 398,9 \\
\hline & B & 515,6 & 233,3 & 251,1 & 10,6 & 17,2 & 223,3 \\
\hline \multirow[t]{2}{*}{ PV6 raso } & A & 170 & 200 & 630 & 10 & 50 & 570 \\
\hline & B & 390 & 160 & 450 & 10 & 30 & 410 \\
\hline \multirow[t]{2}{*}{ PV7 raso } & A & 150 & 230 & 620 & 40 & 30 & 530 \\
\hline & B & 440 & 240 & 300 & 10 & 10 & 280 \\
\hline \multirow[t]{2}{*}{ PV8 raso } & A & 50 & 150 & 500 & 20 & 40 & 740 \\
\hline & B & 350 & 120 & 530 & 10 & 20 & 500 \\
\hline
\end{tabular}

\subsubsection{Relevo}

O relevo na MHC caracteriza-se por apresentar morros em cotas variando entre 460 e $580 \mathrm{~m}$ de altitude, com classes de relevo ondulado (Figura 4). A declividade predominante nas encostas é de 10 a $15 \%$ e nos topos de $5 \%$. As áreas com declividades menores que $2 \%$ se encontram em pequenas várzeas e topos de alguns morros, constituindo menos de $5 \%$ da área total. (Figura 5). 


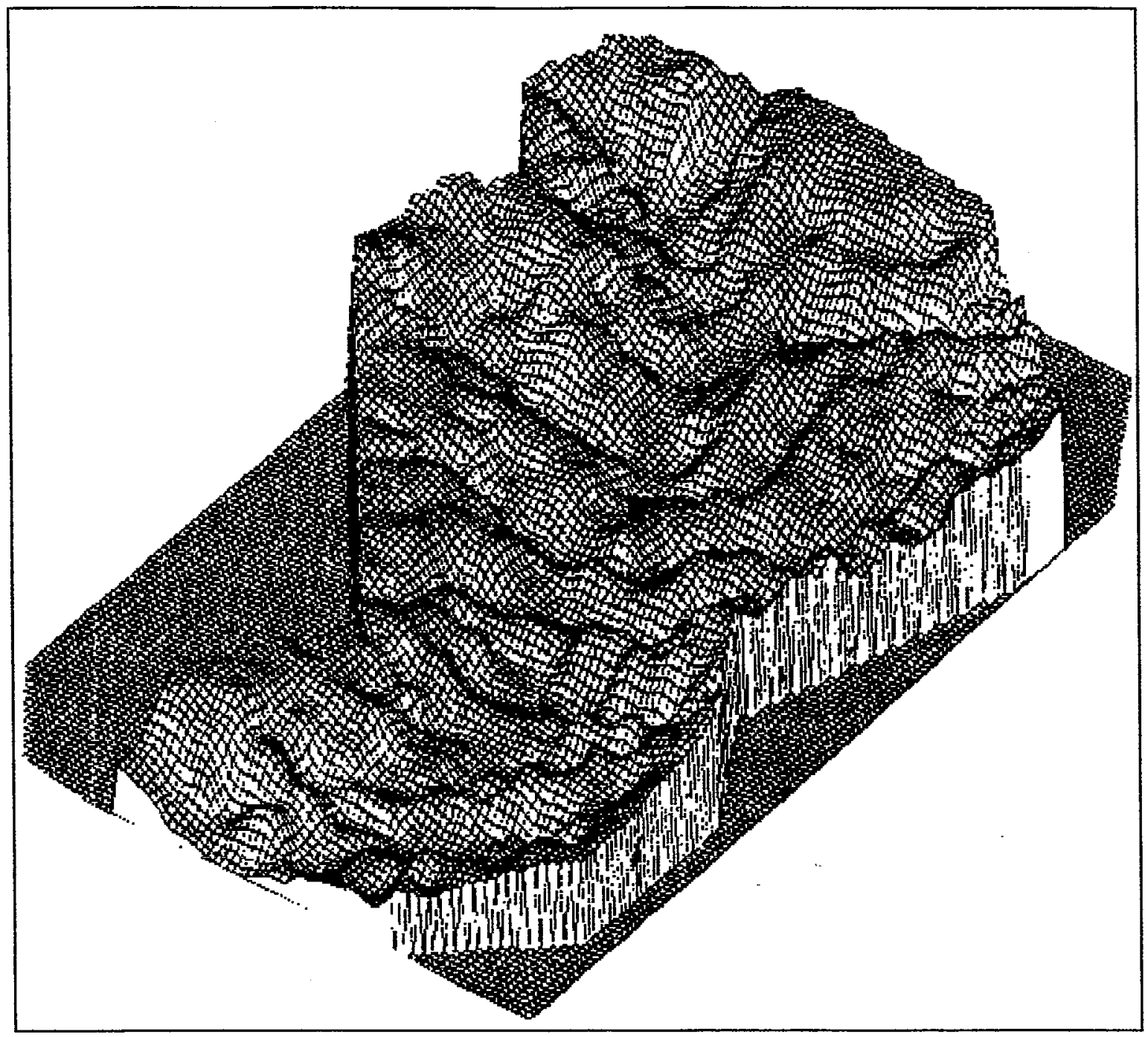

Figura 4 - Bloco-diagrama representando o relevo da Microbacia Hidrográfica do Córrego do Ceveiro. Fonte: Sparovek et al. (1991). 


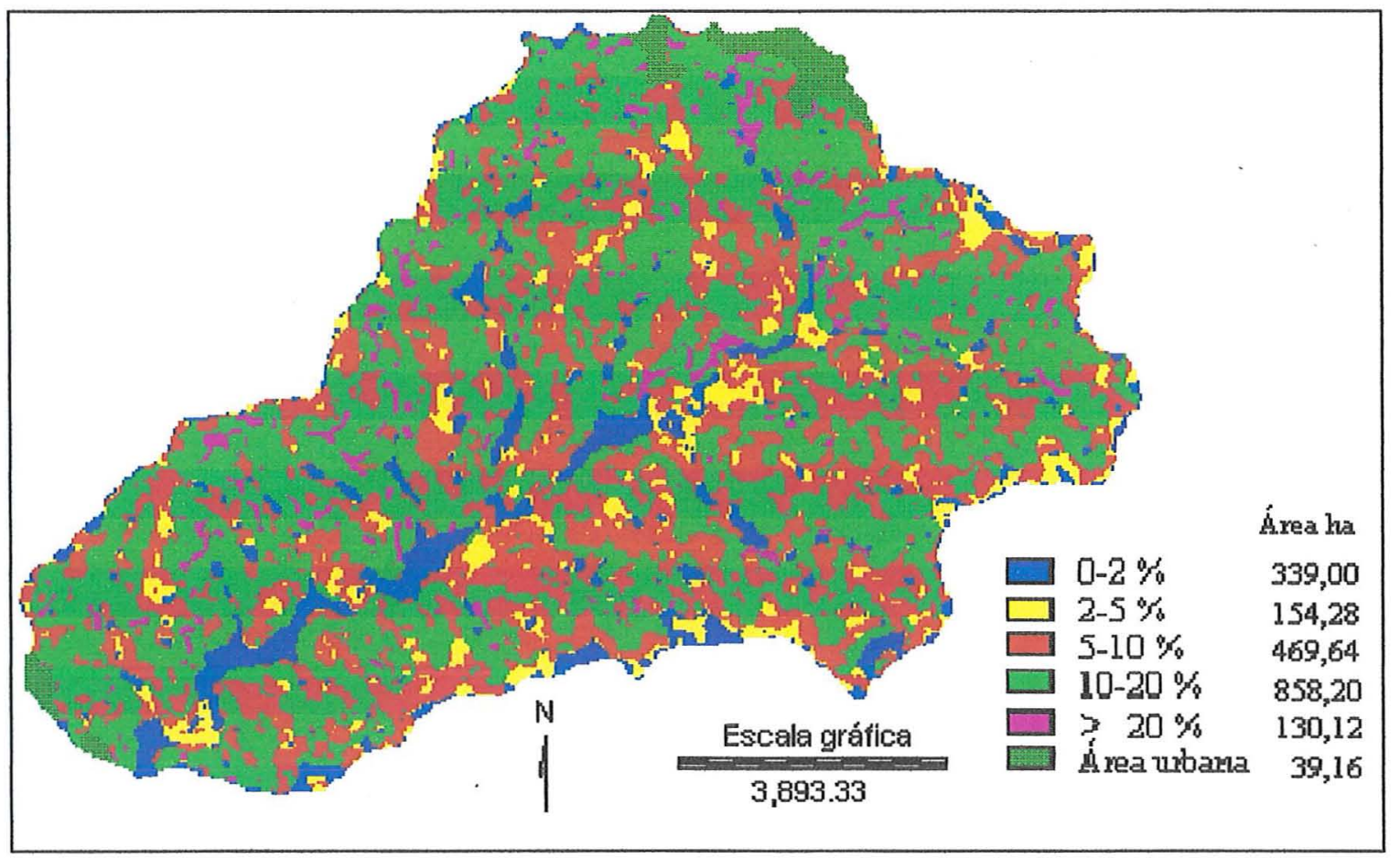

Figura 5 - Mapa de declividades da área de estudo.

\subsubsection{Vegetação}

A vegetação natural é do tipo Floresta mesófila semidecídua, com ocorrência de ripárias nas margens dos cursos d'água. Atualmente essas vegetações praticamente são inexistes, estando restrita a algumas partes da rede de drenagem que compõe o córrego do Ceveiro e nas partes mais movimentadas do relevo. $\mathrm{O}$ desmatamento ocorreu principalmente pelo avanço da agricultura nas últimas décadas, onde a cana-de-açúcar foi e continua sendo a principal cultura da área.

\subsubsection{Clima}

Os dados climatológicos do município de Piracicaba, no período de 1917 a 1989, foram utilizados para caracterizar a bacia (Tabela 3). A distribuição das chuvas é 
caracterizada por apresentar um período chuvoso, que se estende de outubro a março e período seco, de abril à setembro, sendo abrupta a passagem de um período para o outro.

Tabela 3 - Dados Climatológicos do municipio de Piracicaba-SP.

\begin{tabular}{lcccc}
\hline Mês & Temperatura Média & Precipitação & Evapotranspiração & Precip. - Evap. \\
\hline \multirow{3}{*}{ Jan } & $\left({ }^{0} \mathrm{C}\right)$ & $(\mathrm{mm})$ & $(\mathrm{mm})$ & $(\mathrm{mm})$ \\
Fev & 24,0 & 217 & 124 & 93 \\
Mar & 24,7 & 183 & 107 & 76 \\
Abr & 23,9 & 136 & 114 & 22 \\
Mai & 21,0 & 65 & 79 & -14 \\
Jun & 17,6 & 52 & 68 & -16 \\
Jul & 16,8 & 46 & 60 & -14 \\
Ago & 17,2 & 26 & 67 & -41 \\
Set & 18,9 & 29 & 87 & -58 \\
Out & 20,3 & 60 & 96 & -30 \\
Nov & 22,2 & 108 & 125 & -17 \\
Dez & 22,9 & 132 & 132 & 0 \\
\hline
\end{tabular}

Fonte: Sparovek et al. (1991).

O regime térmico do ar varia gradativamente nas estações do ano, com médias mensais mais elevadas no verão, um pequeno decréscimo no outono, valores mais baixos no inverno e acréscimo na primavera.

Pelo sistema de Köppen, a área apresenta clima Cwa, isto é, mesotérmico úmido tropical com inverno seco e temperatura do mês mais quente superior a $22^{\circ} \mathrm{C}$.

$\mathrm{O}$ balanço hídrico é apresentado na Figura 6 . Nele pode-se notar a ocorrência de deficiência de água no solo entre os meses de junho e outubro, e um excesso de água no solo nos outros meses do ano. 


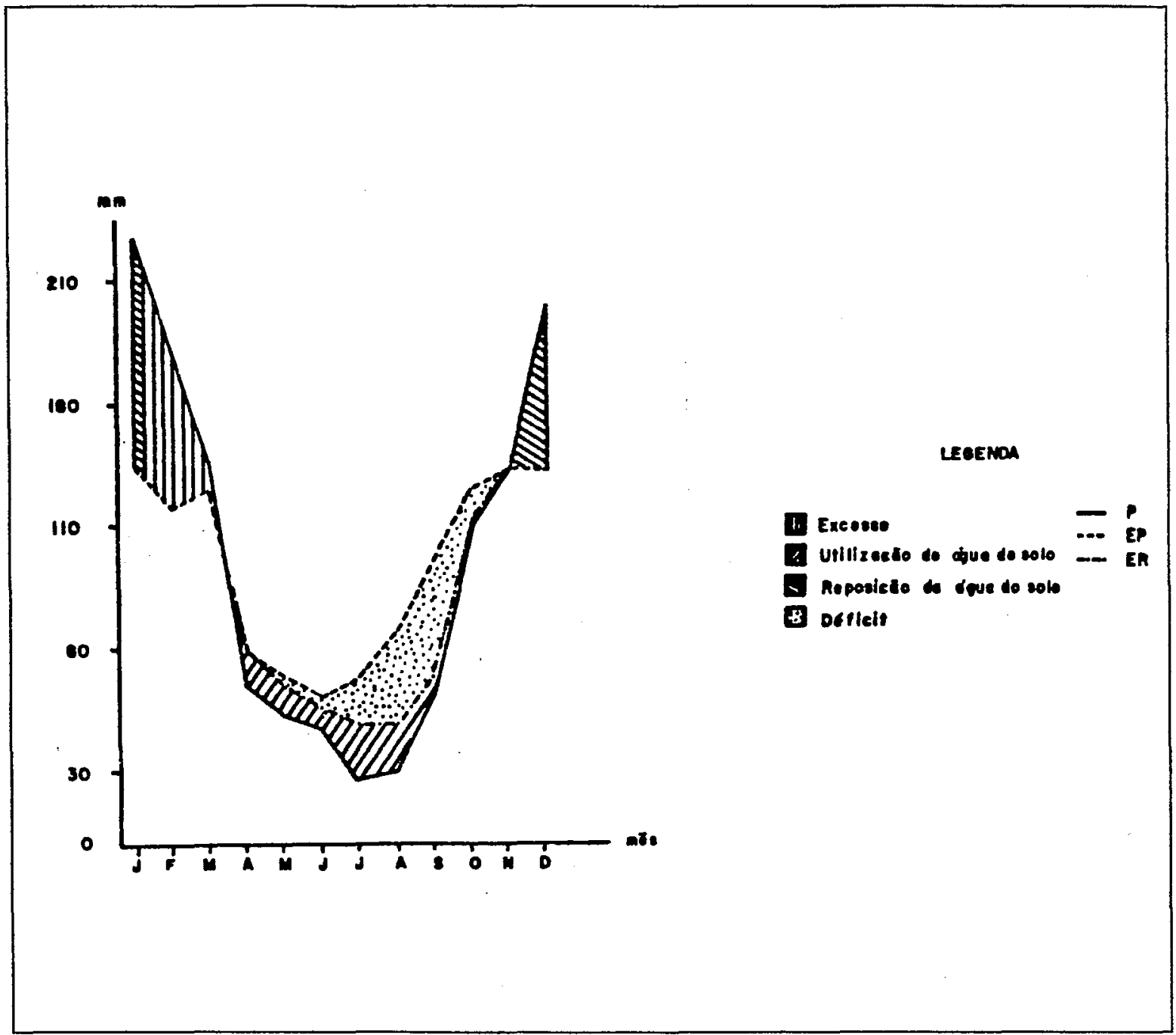

Figura 6 - Balanço Hídrico do Município de Piracicaba, SP. Fonte: Sparovek et al (1991).

\subsubsection{Cartas Planialtimétricas}

A carta planialtimétrica da MHC na escala $1: 10.000$, foi gerada a partir de quatro cartas planialtimétricas, com curvas de nível eqüidistantes em $5 \mathrm{~m}$, na escala 1:10.000 do Plano Cartográfico do Estado de São Paulo, cujo levantamento foi realizado pela Terrafoto, junto ao Governo do Estado de São Paulo e Secretaria de Economia e Planejamento. 
Assim sendo, as cartas planialtimétricas utilizadas foram:

- Folha da Estância Lago Azul (SF23-Y-A-IV-1-SE-B), articulação 070/087;

- Folha de Artemis (SF23-Y-A-IV-1-SE-D), articulação 071/087;

- Folha do Córrego das Ondas (SF23-Y-A-IV-2-SO-A), articulação 070/088;

- Folha da Vila Olímpia (SF23-Y-A-IV-2-NO-E), articulação 069/088.

A partir dessas cartas, foi possível confeccionar-se um mapa planialtimétrico da microbacia, utilizando-se folha de acetato transparente com 0.10 milimetros de espessura e canetas nanquim, o qual foi denominado de Mapa Base. O mesmo foi digitalizado no software Autocad e posteriormente, exportado para o software Idrisi (SIG). Dessa maneira todas as informações cartográficas geradas neste trabalho foram sobrepostas e se encontram georreferenciadas e na mesma escala do mapa base.

\subsubsection{Fotografias Aéreas}

Foram utilizadas fotografias aéreas pancromáticas (preto e branco) verticais, dos anos de:

- 1962, na escala nominal aproximada de 1:25.000 do vôo junto ao IAC (Figura 7).

- 1965, na escala nominal aproximada de 1:60.000 do vôo junto a USAF-AST 10 (Figura 8).

- 1978, na escala nominal aproximada de 1: 35.000 do vôo junto a Terrafoto/IGC (Figura 9).

- 1995, na escala nominal aproximada de 1:25.000 do vôo junto a BASE (Figura 10).

Cada conjunto de fotografias aéreas é composto de pares estereoscópicos, apresentando recobrimentos longitudinais de $60 \%$ e laterais de $30 \%$. Para a obtenção da visão estereoscópica dos pares, foi utilizado estereoscópio de espelhos da marca ZEISS, modelo N2. Para se confeccionar os mapas de uso, também foram utilizadas folhas de acetato transparente com 0,10 milimetros de espessura. 


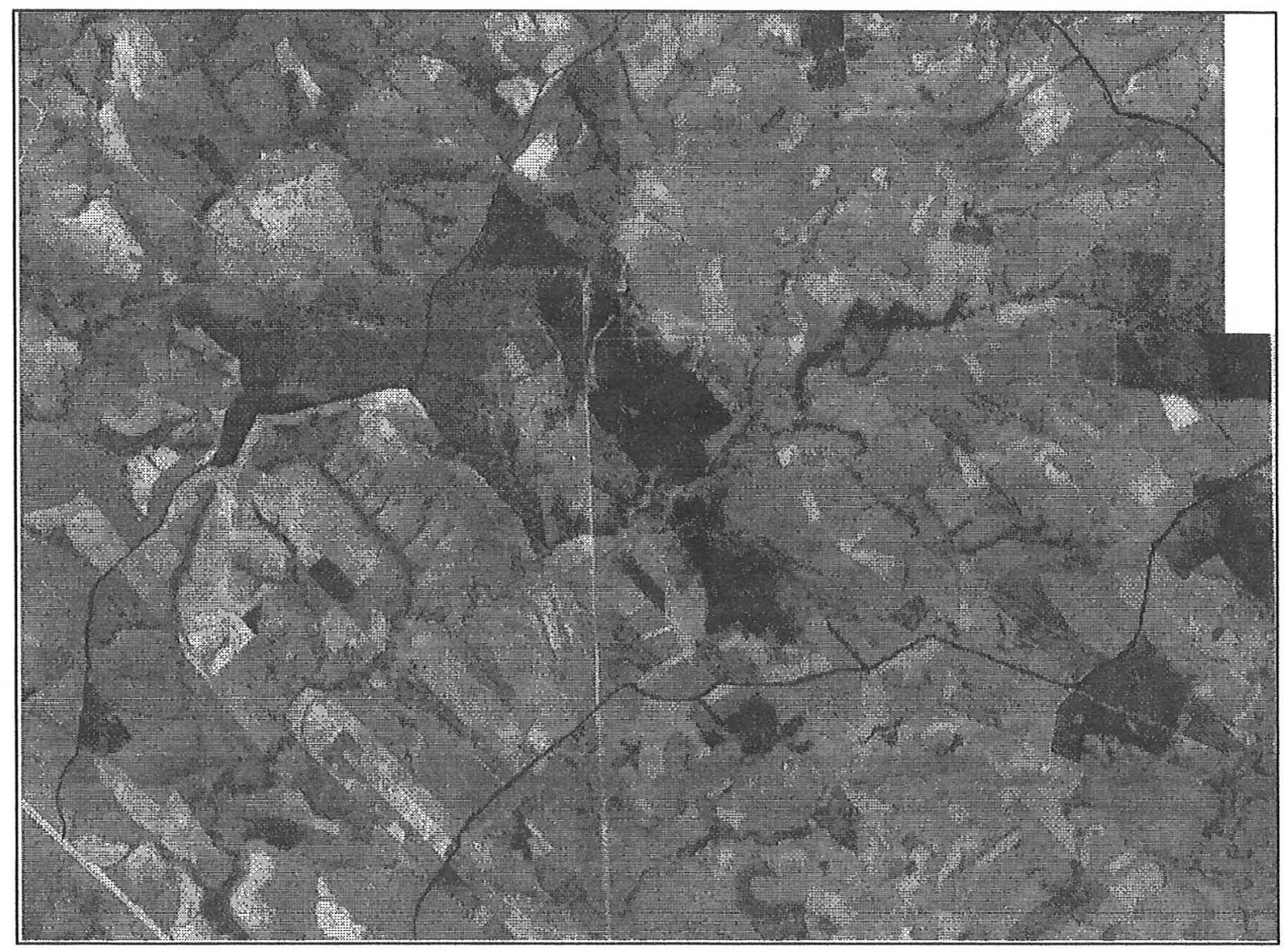

Figura 7 - Fotografia aérea da Microbacia Hidrográfica do Ceveiro do ano de 1962, escala 1: 25.000 . 


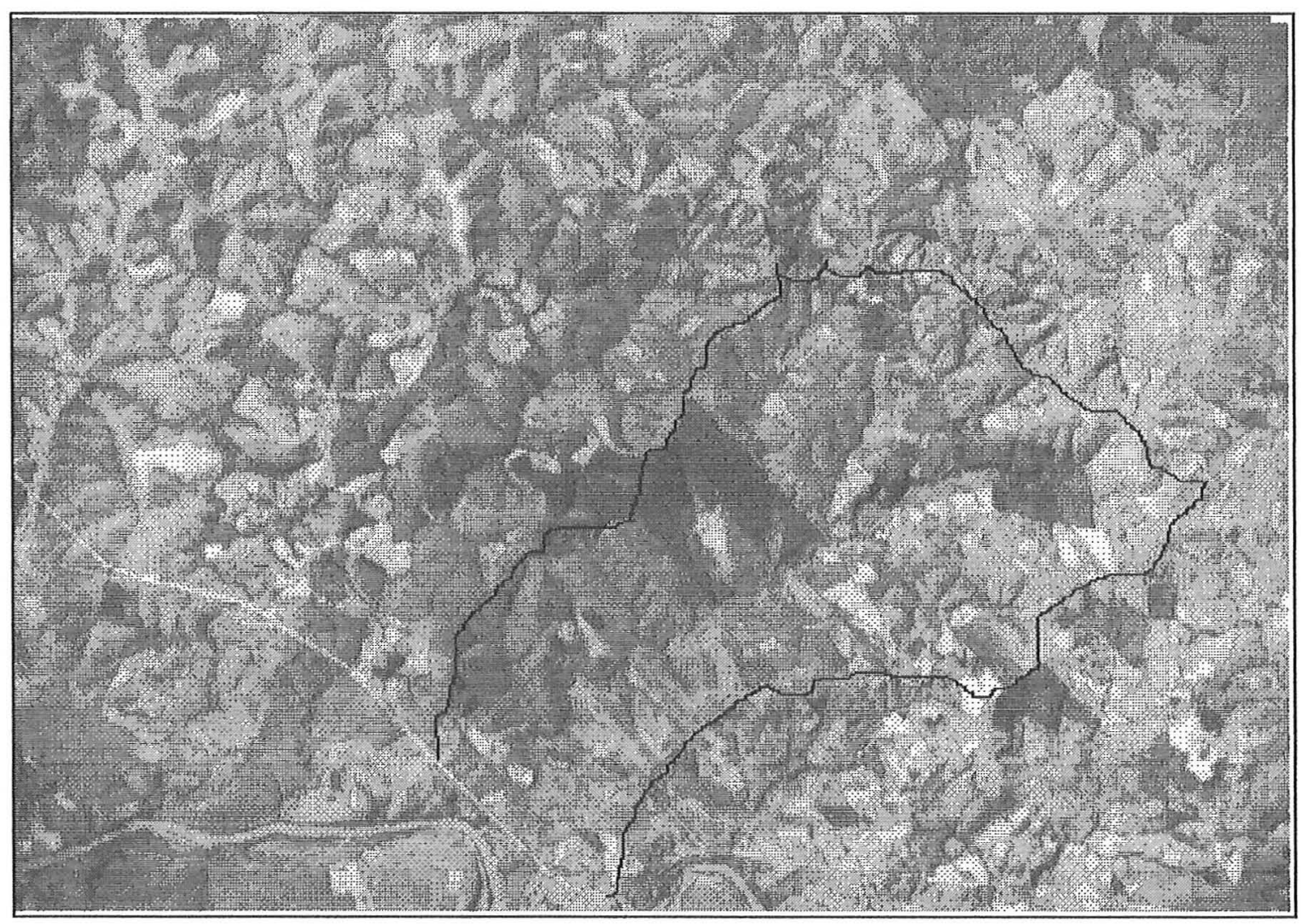

Figura 8 - Fotografia aérea da Microbacia Hidrográfica do Ceveiro do ano de 1965, escala 1: 60.000 . 


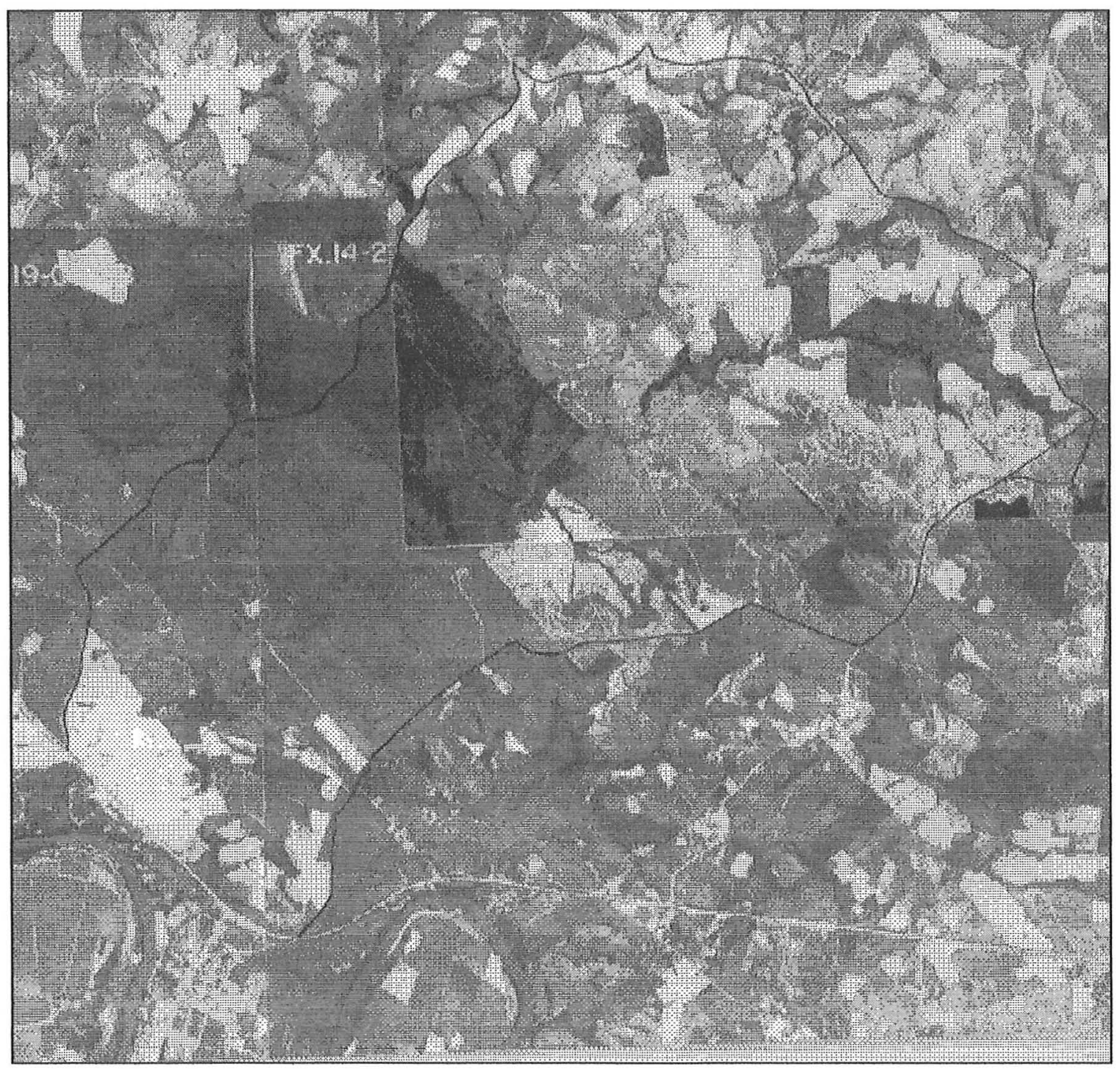

Figura 9 - Fotografia aérea da Microbacia Hidrográfica do Ceveiro do ano de 1978, escala 1: 35.000 . 


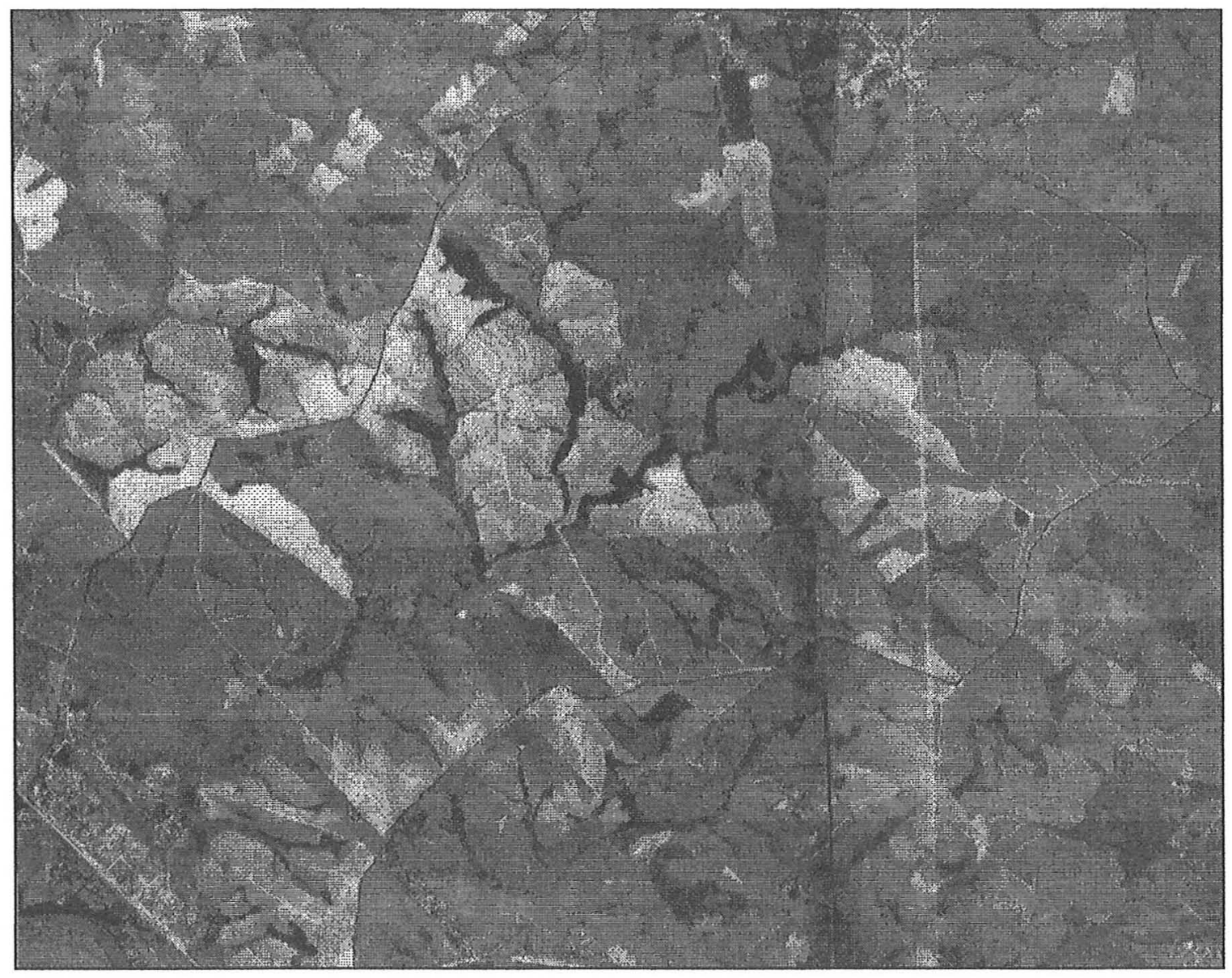

Figura 10 - Fotografia aérea da Microbacia Hidrográfica do Ceveiro do ano de 1995, escala 1: 25.000 . 


\subsubsection{Material de informática}

Para a realização desse trabalho foi utilizado um microcomputador Pentium 166MMX, mesa digitalizadora (Digigraf, modelo Van Gogh, tamanho A0), impressoras e ploter. Três programas foram utilizados, o Autocad versão r12 para DOS, o Idrisi para Windows e o SAMPA (Sistema de Análise Ambiental para Planejamento Agrícola).

\subsubsection{Autocad}

O Autocad é um programa gráfico. É um "CAD" ( desenho com auxilio de computador), desenvolvido para rodar em uma vasta quantidade de plataformas e sistemas operacionais. É compatível com microcomputadores do tipo IBM-PC, nos sistemas operacionais DOS e Windows.

O programa foi utilizado como "via de acesso" entre os dados (mapas analógicos em papel ou poliester) e os Sistemas de Informações Geográficas (SIGs), neste caso o Idrisi.

\subsubsection{Sistema de Informação Geográfica (SIG)}

Para a execução desse trabalho foi utilizado o software autocad, para a digitalização dos mapas e o Sistema de Informação Geográfica, Idrisi, Easteman (1992), sendo esse amplamente utilizado mundialmente, devido a facilidade de aquisição e operatividade do programa. O Idrisi foi desenvolvido para computadores IBM-PC, pela Clark University (EUA). Apresenta-se composto basicamente por cinco módulos de programas :Core, Análise Geográfica, Processamento de Imagens, Análises Estatísticas e Periféricos. Dessa maneira, o diagrama de blocos da Figura 11, apresenta resumidamente o processo metodológico para a obtenção da Cronologia do Uso da Terra, na microbacia do Ceveiro entre os anos de 1962 a 1995. 


\subsubsection{Sistema de Análise Ambiental para Planejamento Agrícola (SAMPA)}

O programa SAMPA, foi desenvolvido por Koffler et al. (1992), seguindo os fundamentos gerais dos trabalhos do tipo "Levantamento da aptidão agrícola das terras", como os descritos por Ramalho et al. (1978) e Oliveira \& Berg (1985), tendo sido incluídas diversas adaptações necessárias para adequar os critérios a um sistema automatizado. O programa requer microcomputadores da linha IBM-PC.

\subsection{Metodologia}

O método consistiu em gerar uma base de dados do uso da terra, através de interpretação em fotografias aéreas a qual foi digitalizada no programa Autocad e processada em SIG (Idrisi). No programa Idrisi foram gerados vários produtos temáticos, entre eles um mapa de uso ideal da terra. $O$ mesmo foi comparado com a aptidão agrícola gerada pelo programa SAMPA. Para tanto, vários outros passos foram desenvolvidos, podendo-se ter uma melhor compreensão da metodologia utilizada observando-se a Figura 11.

\subsubsection{Elaboração da base de dados}

Essa etapa consistiu basicamente da interpretação das fotografias aéreas, nas diferentes épocas, na confecção dos mapas de uso da terra em papel vegetal e finalmente na digitalização e exportação dos dados no programa autocad para o Idrisi.

\subsubsection{Interpretação das fotografias aéreas}

Com o objetivo de se identificar o uso da terra, nos anos de 1962, 1965, 1978 e 1995, realizou-se a fotointerpretação das fotografias aéreas com auxilio de estereoscópio de espelho, segundo metodologia descrita por Rabben (1960), na qual se delimita a área 
útil ou efetiva de cada fotografia. Após esse passo, utilizou-se então, de acordo com as orientações de Anderson (1982), técnicas de sobreposição produzidos com folhas de acetato transparente com 0.10 milímetros de espessura, para a confecção dos mapas de uso.

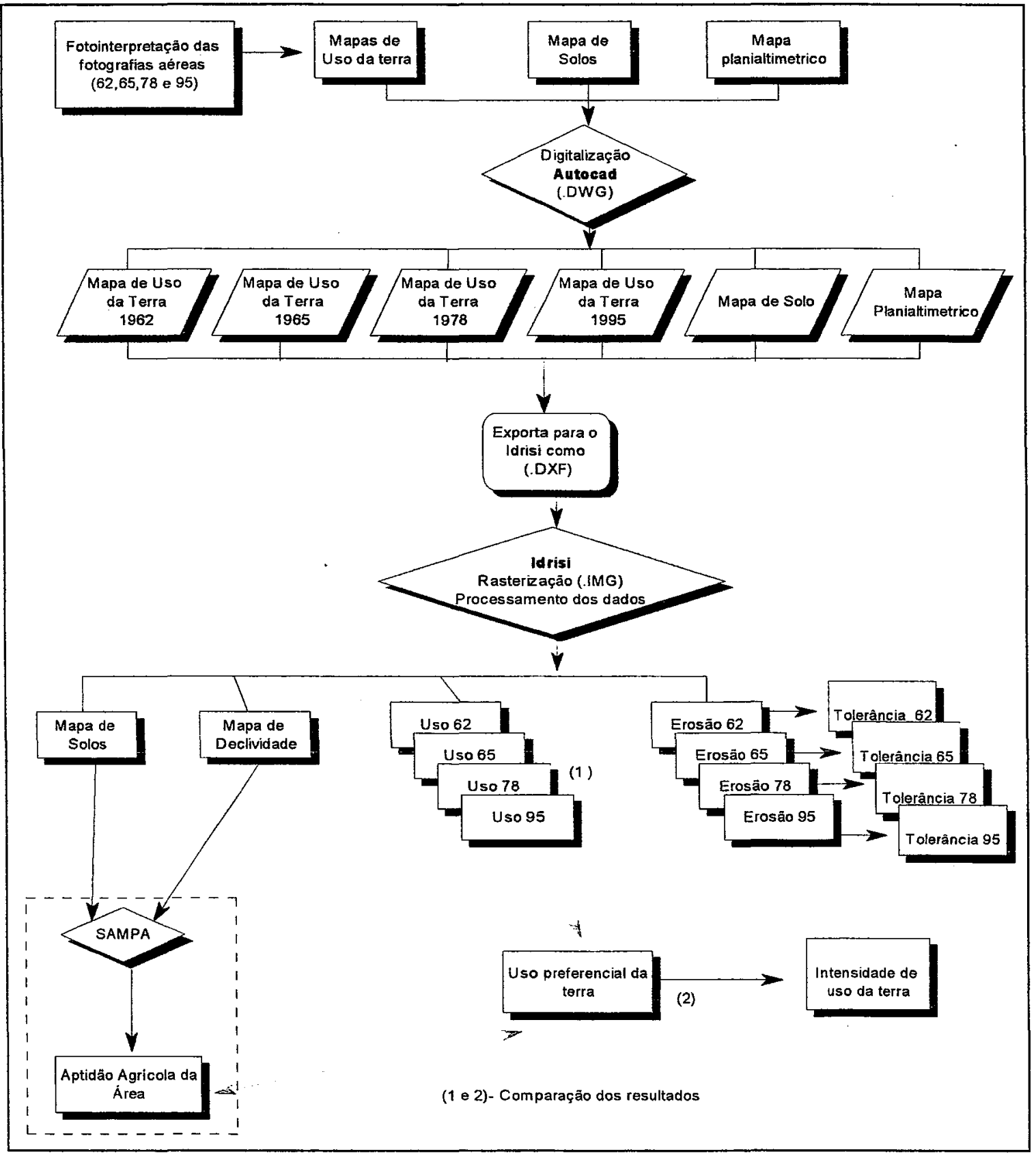

Figura 11- Representação esquemática da metodologia utilizada. 
Para se identificar os diferentes usos da terra foi necessário utilizar-se de padrões. Os usos podem ser diferenciados pela tonalidade, textura, padrão, forma, dimensão, sombra, cor, sítio topográfico e relações de aspecto (Santos et al., 1980). Adotou-se, portanto uma legenda com os seguintes tipos de uso da terra:

1- Área urbana;

2- Cana-de-açúcar;

3- Culturas anuais;

4- Culturas perenes;

5- Mata ciliar;

6- Pasto;

7- Pasto sujo;

8- Reflorestamento;

9- Mata;

10- Represa.

\subsubsection{Digitalização da base de dados}

A digitalização dos dados consistiu em transferir as informações dos mapas de uso da terra para o computador. Esse processo foi realizado pelo programa Autocad, com auxílio de mesa digitalizadora. Os arquivos gerados, no formato vetorial, apresentam extensão .DWG.

\subsubsection{Conversão dos dados para o Idrisi}

O mapas digitalizados no Autocad, foram poligonizados pelo comando Bpoly e convertidos para o formato .DXF através do comando DXFOUT, já que o programa Idrisi não importa dados .DWG. Dessa forma, os arquivos gerados em .DXF puderam ser lidos pelo programa Idrisi (Figura 11). 


\subsubsection{Processamento dos dados no programa Idrisi}

\subsubsection{Rasterização dos dados}

Os dados no formato .DXF, se apresentavam no formato vetor, impedindo o processamento. Com os comandos REFORMAT e POLYRAS, fez se a conversão do formato vetor para raster. Assim os mapas foram visualizados e processados pelo programa, apresentando extensão .IMG imagem (Figura 11).

\subsubsection{Erosão do Solo}

Para cada ano em estudo, foi gerado um mapa de perdas de solo (erosão do solo), utilizando-se a metodologia descrita por Ranieri (1996). Com isso, os mapas de perdas de solo, foram gerados pela sobreposição de vários mapas no Idrisi, contendo os parâmetros da Equação Universal de Perda de Solo, EUPS (Figura 12).

\subsubsection{Obtenção dos fatores da Equação Universal de Perdas de Solos (EUPS) para estimativa de perdas de solo}

a. Fator erodibilidade da chuva (R) - Para toda a área foi considerada um valor constante, igual à $6750 \mathrm{MJ} . \mathrm{mm} /$ ha.h.ano, valor de erosividade utilizado para Piracicaba. Para gerar o mapa de erosividade da chuva foi utilizado o módulo "Assign".

b. Fator erodibilidade do solo (K) - utilizou-se o modelo matemático desenvolvido por Denardin (1990), baseado no nomograma de Wischmeier et al. (1971). Assim os dados físicos e químicos dos solos da microbacia foram aplicados ao modelo proposto:

$$
K=0,00000748(M)+0,00448059(p)-0,06311750(D M P)+0,01039567\left(r^{\prime}\right)
$$

onde: 
$\mathrm{K}=$ valor estimado para erodiblidade do solo, em t.ha.Mj.mm;

$\mathrm{M}=$ variável " $\mathrm{M}$ " calculada a partir de parâmetros granulométricos: \% novo silte $\mathrm{x}$ (\% novo silte $+\%$ de nova areia);

$\mathrm{p}=$ permeabilidade do perfil codificada conforme Wischmeier et al. (1971), onde:

Classes de permeabilidade:

$1=$ rápida

2 = moderada a rápida

$3=$ moderada

$4=$ lenta a moderada

$5=$ muito lenta

$\mathrm{DMP}=$ diâmetro médio ponderado das partícula menores que $2 \mathrm{~mm}$ expresso em $\mathrm{mm}$, $\mathrm{r}=$ relação entre o teor de matéria orgânica e o teor da nova areia (MO x \% nova areia)/ 100

O modelo foi testado para os solos do Brasil e dos EUA, cujos valores de erodibilidade já eram conhecidos através de determinação direta no campo. De acordo com Denardin (1990) o coeficiente de determinação do teste foi de 0,9767 e o erro padrão estimado de 0,006 t.ha.h/ha.mj.mm (teste F).

Os valores estimados de erodibilidade para os solos da área se encontram na Tabela 4.

Após obtidos os valores de erodibilidade para cada solo da microbacia, os seus respectivos valores foram atribuídos, utilizando-se do módulo "Assign". 


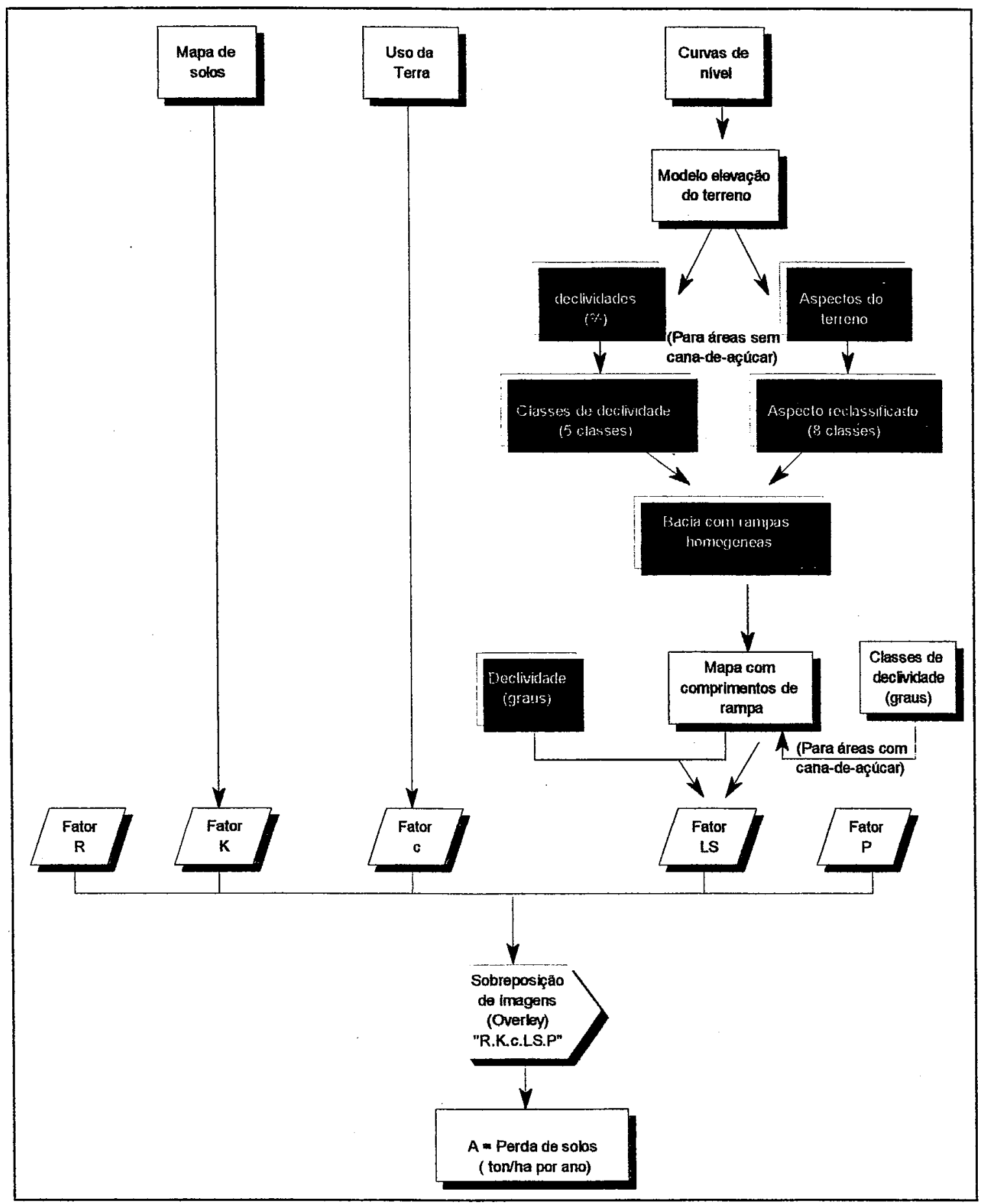

Figura 12 - Representação esquemática da obtenção dos mapas de perdas de solos para os anos de 1962, 1965,1978, e 1995) pelo método descrito por Ranieri (1996). 
Tabeia 4 - Valores de erodibilidade para os solos da Microbacia Hidrográfica do Ceveiro.

\begin{tabular}{lc}
\hline \multicolumn{1}{c}{ Classes de Solo } & Erodibilidade (K) t.ha.h/ha.MJ.mm \\
\hline PV-8 & 0,089 \\
PV-1, PV-3 & 0,085 \\
PV-2 & 0,078 \\
PV-5 & 0,074 \\
PV-4 & 0,073 \\
PV-7 & 0,070 \\
PV-6 & 0,060 \\
PV-2 e PV-4 (raso) & 0,074 \\
PV-7 (raso) & 0,069 \\
PV-6 (raso) & 0,066 \\
PV-1 (raso) & 0,064 \\
PV-5 (raso) & 0,061 \\
PE & 0,061 \\
TE/TEP & 0,037 \\
Li-2 e Li-5 & 0,054 \\
Li-1 & 0,052 \\
Li-6 & 0,043 \\
Li-4 & 0,042 \\
Li-3 & 0,037 \\
Li-7 & 0,031 \\
Cb-2 & 0,074 \\
Cb-3 & 0,072 \\
Cb-1 & 0,051 \\
Hi-2 & 0,063 \\
Hi-1 + Al & 0,058 \\
\hline
\end{tabular}


c. Fator comprimento e grau de declive (LS)

Utilizou-se o método proposto por Rocha et al. (1996), com algumas modificações. Para tanto foram necessárias várias combinações no software Idrisi. A partir da imagem de curvas de nível obtidas pela digitalização do mapa planialtimetrico na escala 1:10.000, gerou-se um modelo digital de elevação do terreno pela interpolação destas curvas feita pelo módulo "Intercon". Esse mapa serviu de base para caracterizar o terreno quanto à declividade e aspectos do terreno (orientação das vertentes num raio de $0^{\circ}$ a $360^{\circ}$ ), por meio do módulo "Surface". Os mapas de aspectos do tereno foi reclassificado em oito direções de $45^{\circ}$ em $45^{\circ}$ graus, o que resultou na divisão da microbacia em direções de vertentes Norte, Nordeste, Leste, Sudeste, Sul, Sudoeste, Oeste e Noroeste. O mapa de declividades foi reclassificado em cinco intervalos de declividades em porcentagens $(0-2 \%, 2-5 \%, 5-10 \%, 10-20 \%$ e $>20 \%)$. 0 mapa de aspectos e declividades reclassificados foram sobrepostos pelo módulo "Crosstab", obtendo todas as combinações possíveis entre os dois mapas. Utilizando-se o módulo "Group", obteve-se um mapa de polígonos isolados, os quais representam cada rampa homogênea da microbacia, nas quais foram calculados os respectivos comprimentos (em metros). Para tanto foram extraídos os valores máximos e mínimos da altura de cada polígono (em metros), bem como as declividades médias de cada rampa (em porcentagem). $\mathrm{O}$ comprimento de rampa foi obtido pela equação:

$$
\mathbf{c}=\mathbf{h} / \operatorname{sen} \alpha
$$

onde:

$\mathrm{c}=$ comprimento de rampa $(\mathrm{m})$;

$\mathrm{h}=$ diferença de altura da rampa $(\mathrm{m})$;

$\alpha=$ declividade média do polígono (\%).

O mapa final de LS foi obtido no módulo "Scalar" do Idrisi, através da aplicação da formula: 


$$
L S=0,0984 c^{0,63} d^{1,18}
$$

onde:

LS = fator topográfico;

$\mathrm{c}=$ comprimento de rampa $(\mathrm{m})$

$\mathrm{d}=$ grau de declive $(\%)$.

Para a cultura da cana-de-açúcar, o cálculo do fator LS foi realizado de uma forma diferente. Os terraços nessa cultura são construídos a cada $4 \mathrm{~m}$ de desnivel. Assim sendo, partindo-se do mapa de classes de declividade, foi possível calcular-se os valores correspondentes ao comprimento de rampa:

- $0-2 \%$ de declividade: $140 \mathrm{~m}$ de rampa;

- $2-5 \%$ de declividade: $140 \mathrm{~m}$ de rampa;

- $5-10 \%$ de declividade: $67 \mathrm{~m}$ de rampa;

- $10-20 \%$ de declividade: $33 \mathrm{~m}$ de rampa;

- $>20 \%$ de declividade: $25 \mathrm{~m}$ de rampa.

d. Fator uso-manejo (C)

Para o fator uso-manejo, não foram considerados valores específicos para cada estágio da cultura. Foram utilizados valores obtidos em literatura para as diversas culturas descritas na Microbacia Hidrográfica do Ceveiro, nos respectivos anos de uso da terra $(62,65,78$ e 95). Os valores encontrados para este fator são expressas na Tabela 5.

Os mapas de uso-manejo foram obtidos para cada ano em estudo $(62,65,78 \mathrm{e}$ 95) através do módulo "Assign", nos mapas de uso da terra. 
Tabela 5- Fatores uso-manejo e práticas conservacionistas para as culturas encontradas na Microbacia Hidrográfica do Ceveiro.

\begin{tabular}{lcc}
\hline \multicolumn{1}{c}{ Uso da terra } & Fator C & Fator P \\
\hline Cana-de-açúcar & $0,11^{1}$ & 0,5 \\
Cultura Perene & $0,01^{2}$ & 1,0 \\
Cultura Anual & $0,55^{3}$ & 0,5 \\
Pasto & $0,008^{4}$ & 1,0 \\
Pasto Sujo & $0,008^{4}$ & 1,0 \\
Reflorestamento & $0,001^{2}$ & 1,0 \\
Mata & $0,0001^{2}$ & 1,0 \\
Mata ciliar & $0,0001^{2}$ & 1,0 \\
\hline
\end{tabular}

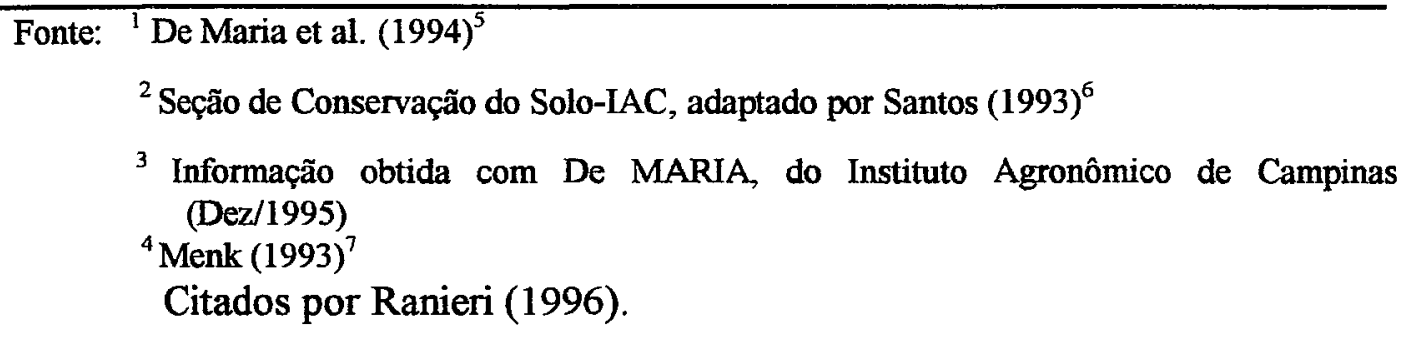

e. Fator práticas conservacionistas $(\mathrm{P})$

Pela observação das fotografias aéreas dos diferentes anos de estudo, foi possível verificar-se que as práticas conservacionistas foram adotadas em todos os anos e em larga escala. Dessa forma atribuiu-se o valor 0,5 para $\mathrm{P}$, o que significa que toda a área de

\footnotetext{
${ }^{5}$ DE MARIA, I. C.; LOMBARDI NETO, F; DECHEN, S.C.F. al. Fator equação Universal de Perdas de Solo (EUPS), para cultura de cana-de-açucar In: REUNIÃO BRASILEIRA DE MANEJO E CONSERVAÇÃo DO SOLO E DA AGUA, 10., Florianópolis, 1994. Resumos, p. 148-149.

${ }^{6}$ SANTOS, M. F. Subsídios para o planejamento conservacionista da bacia hidrográfica do Ribeirão do Feijão (São Carlos, Itirapina e Analândia, SP) São Carlos. Dissertação (Mestrado) Escola de Engenharia de São Carlos, Universidade de São Paulo.

${ }^{7}$ MENK, P.C.M. Avaliação econômica do controle da erosão na Microbacia do Ribeirão Iperó. Em Araçoiaba da Serra, Estado de São Paulo. Piracicaba. 1993. Dissertação (Mestrado) Escola Superior de Agricultura "Luiz de Queiroz", Universidade de São Paulo.
} 
estudo apresentou práticas de plantio em contorno. O mapa do Fator $\mathbf{P}$ foi, então, considerado uniforme.

\subsubsection{Sistema de análise ambiental para planejamento agrícola (SAMPA)}

O presente programa foi desenvolvido por Koffler (1992), consiste em elaborar uma base de dados com as variáveis descritas a seguir e preenchimento de planilhas. Basicamente, este programa se utiliza do mapa de solos e de declividade da área em estudo, como também dos dados químicos e fisicos dos solos. Um subprograma organiza, automaticamente, tabelas de solos $\mathrm{x}$ declividades, características dos solos e classificação das limitações dos solos.

As variáveis são as seguintes:

a) Classes de declividade associadas a cada classe de solo

b) Características químicas e fisicas

- Capacidade de troca catiônica (Horizontes A e B);

- Saturação por bases (Horizontes A e B);

- Saturação por alumínio (Horizontes A e B);

- Saturação por sódio e ou condutividade elétrica; profundidade efetiva;

- Natureza do impedimento fisico;

- Teor de argila (Horizontes A e B);

- Razão textural;

- Natureza das argilas predominantes;

- Pedregosidade.

Após a análise inicial das limitações do solo, o programa compara as limitações e as exigências das culturais de quatro grande grupos a saber: (1) Ciclo curto, (2) Ciclo longo, (3) Pastagens e (4) Silvicultura. Para Ciclo curto consideram-se todas as culturas semeadas e colhidas num período que não ultrapasse 6 meses, (trigo, milho, hortaliças, etc), para ciclo longo, representado pela cana-de-açúcar, como culturas de ciclo 
vegetativo maior que um ano e culturas perenes. Para pastagens, consideram-se áreas em regime de pasto. Silvicultura, consideram-se todas florestas plantadas pelo homem para produção de matéria prima.

Dessa forma, após a comparação o programa propõe um uso preferencial da área em estudo, dando prioridade para áreas boas e regulares para cada grupo de culturas. As culturas de ciclo curto, mais exigentes e por expor mais os solos aos processos erosivos, ocupam os melhores solos. Seguindo essa classificação em ordem decrescente de exigência e crescente de proteção do solo pela cultura.

Por fim, o programa propõe o cruzamento do mapa de Uso Preferencial e o mapa de Uso Atual, gerando um mapa de Intensidade de Uso. 


\section{RESULTADOS E DISCUSSÃO}

\subsection{Fotointerpretação do uso da terra}

Com o intuito de se realizar uma cronoseqüência do uso da terra na Microbacia Hidrográfica do Ceveiro (MHC), foi realizado um levantamento dos vôos aerofotogramétricos. Assim sendo, foram utilizadas fotografias aéreas, pancrômaticas, de diferentes datas $(1962,1965,1978$ e 1995) e com diferentes escalas (1:35.000, 1:25.000 e 1:60.000).

$\mathrm{Na}$ interpretação das fotografias aéreas para a avaliação do uso da terra considerou-se como características importantes para a melhor identificação dos alvos, a tonalidade, textura, porte, telhado e aspectos associados. Assim sendo, para cada uso da microbacia foram verificadas as características desses elementos, de acordo com a escala utilizada (Tabela 6). A visão estereoscópica proporcionada pelas fotografias aéreas foi de grande valia na determinação dos usos da terra, assim como a tonalidade, textura, porte, telhado e aspectos associados. A cana-de-açúcar é um bom exemplo, pois foi identificada principalmente pelos aspectos associados, como os carreadores de fundo. A observação dos aspectos associados auxilia na fotointerpretação, concordando com Rabben (1960), Ray (1963), Ricci \& Petri (1965) e Santos et al. (1980).

A discriminação dos aspectos ambientais da MHC foi possivel pela utilização de fotografias aéreas, possibilitando também um monitoramento das mudanças espaço temporais do meio fisico, concordando com autores como Steiner (1970), Paiva et al. (1976), Koffler (1982), Politano et al. (1990) e Lobão (1996). 
Durante o trabalho de fotointerpretação, verificou-se que as fotografias de escala 1:35.000, foram as que mais facilitaram a interpretação do uso da terra de 1978 , sendo que o mapa gerado foi o mais enriquecido em detalhes. Da mesma forma o trabalho em fotografias de escala 1:25.000, também foi de fácil interpretação, gerando um bom nível de detalhamento para os anos de 1962 e 1995.

A chave de interpretação descrita na Tabela 6 , não difere das descritas por Marchetti \& Gárcia (1978), Koffler et al. (1979) e Borges et al. (1993), onde todos se utilizaram de fotografias aéreas na escala 1:35.000, a qual proporcionou um bom nível de detalhamento.

Por outro lado, verifica-se a perda de detalhamento na escala 1:60.000 em relação à 1:25.000 e uma igualdade de informações entre as escalas 1:25.000 e 1:35.000.

A escala 1:60.000 foi a que mais exigiu do intérprete, pois a mesma, foi de dificil interpretação, pela perda de detalhes. Em 1977, Demétrio verificou que ocorreu perda de detalhamento de rede de drenagem quando comparadas as escalas 1:8.000 e 1:60.000. Por outro lado, a avaliação do uso da terra utilizando materiais de diferentes escalas obtendo bons resultados também foi realizadas por vários autores. Koffler et al. (1979) também constataram que as fotografias aéreas na escala 1:35.000 proporcionaram um maior detalhamento da área. Borges et al. (1993) compararam o uso de fotografias aéreas na escala 1:35.000 e imagens LANDSAT na escala 1:100.000, enfatizando o maior detalhamento das fotografias aéreas. Lobão (1996) justificou a necessidade de utilização das fotografias aéreas em estudos ambientais devido a baixa resolução das imagens de satélite. 


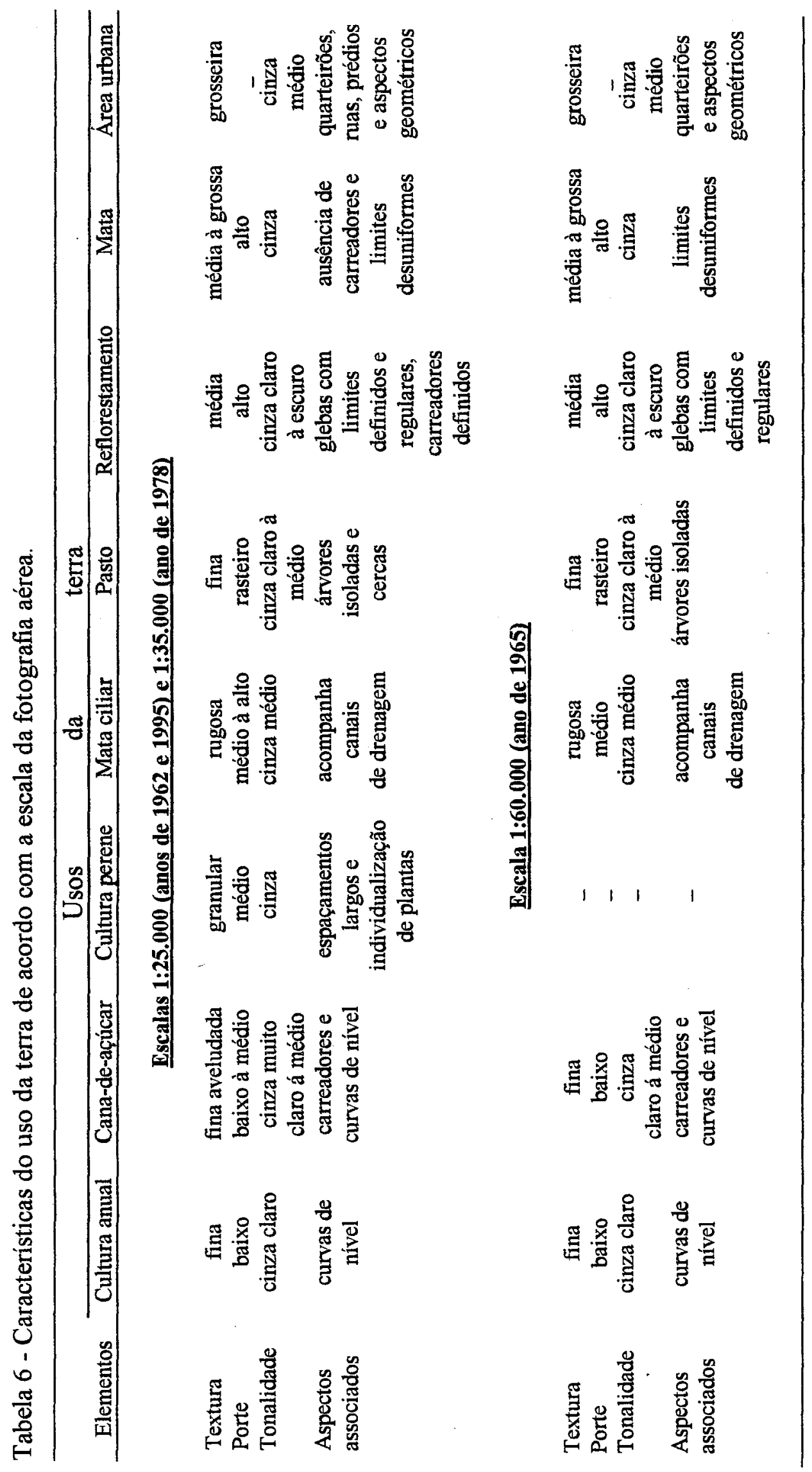




\subsection{Cronologia do uso da terra na Microbacia Hidrográfica do Ceveiro}

O estudo do uso da terra é de grande importância para a melhor compreensão da interação do homem com o ambiente ao longo do tempo, por facilitar as tomadas de decisões futuras, com o intuito da melhor adequação do uso da terra aos recursos naturais. $\mathrm{O}$ sensoriamento remoto juntamente com o geoprocessamento, vieram auxiliar o estudo da terra, bem como o monitoramento de processos evolutivos (tais como uso da terra), possibilitando nesse trabalho a determinação dos mapas de uso da terra em diferentes anos, concordando com Davidson (1992) e Rocha et al. (1996).

Os cenários das ocupações da MHC, dos anos de 1962; 1965; 1978 e 1995, bem como suas respectivas áreas, onde todos os dados foram concebidos pelo SIG, permitira a manipulação dos dados, os quais podem ser observadas na Tabela 7 e nas Figuras 13, 14, 15 e 16, concordando com Alves (1990) e Câmara (1993).

A cana-de-açúcar foi a cultura que mais aumentou em toda a área, pois em 1962 ocupava $16 \%$ da área e em 1995, aumentou para $66 \%$ (Tabela 7). Tal aumento foi mais significativo de 1978 a 1995, que atingindo $40 \%$ da área. Um dos fatores responsáveis por esse aumento foi o Proalcool, implantado em 1973, que visava a substituição da gasolina pelo álcool. Outro fato que contribuiu, foi a proximidade da usina de moagem.

Politano et al. (1983) também constataram através de fotografias aéreas na Região de Monte Alto-SP, mudanças representativas nas áreas canavieiras, devido aos dois fatores anteriormente citados.

As áreas de pastagens também contribuíram em área para a expansão da cultura canavieira, sendo que em 1962 ocupava 578,64 ha (29\% da área), e em 1995 ocupava 277,64 ha (14\% da área), ou seja uma diminuição de $48 \%$ de áreas com pastagem (Tabela 7). Em 1978, as áreas com pasto ocupavam 840,76 ha ( $42 \%$ do total), tendo sua maior queda com o aumento das áreas de cana de 1978 para 1995, (cerca de 33 \% da área), (Figura 13 a 16). Sparovek \& Lepsch (1992) constaram que a expansão canavieira, entre 1962 e 1991 na região de Piracicaba, ocorreu principalmente nas áreas de 
pastagens. Borges et al. (1993), verificaram não haver diferenças nas áreas ocupadas por cana-de-açúcar entre 1978 e 1991 na região de Santa Bárbara D’Oeste. Essa cultura ocupava $66 \%$ da área em 1991, sendo bem mais alto que os $34,22 \%$ encontrados por Koffler et al. (1980) na região de Jaú, porém, semelhante aos 66,3 \% ocupados em 1995 pelo presente trabalho.

Observa-se na Tabela 7 também se observa uma diminuição das áreas de pastagens entre 1962 e 1995. Tal fato, também pode ter tido a contribuição do aumento da área urbana concordando com Borges et al. (1993), podendo ser observado nas Figuras 13 e 16, onde existe uma grande área de pasto próxima a área urbana (então com 2,6 ha). Em 1995, porém a área urbana avançou nas áreas de pastagem, como também de cultura anual.

A cultura anual em 1962, ocupava cerca de $32 \%$ da área de estudo, sendo que em 1995 passou a ocupar 0,15 \%, ocorrendo uma diminuição de 99 \% da área plantada. É interessante ressaltar que em 1962 o milho compunha a maior parte das culturas anuais, sendo que o mesmo veio perdendo espaço para a cultura da cana-de-açúcar principalmente no ano de 1978, (Figura 17). Tais resultados diferem dos obtidos por Sparovek \& Lepsch (1992) para os quais a pastagem na Região de Piracicaba foi a cultura que mais cedeu áreas para a expansão da cana-de-açúcar.

O reflorestamento em 1962, ocupou 283,72 ha (14\% da área total) e em 1995 , 120 ha (6\% da área total), diminuindo $42 \%$ (Tabela 7) Da mesma forma, Silva et al. (1993) verificaram um aumento no desmatamento na região de Ubajara (CE) durante um período de 27 anos. A mata nativa apresentou um aumento de $33 \%$, passando de 45,08 ha em 1962 para 134,08 ha em 1995, que juntamente com a cultura da cana-de-açúcar, apresentaram um aumento de área de 1962 a 1995. Alencar et al. (1996) constataram haver uma regeneração de áreas de floresta secundária, quando comparadas à épocas distintas entre 1984 e 1991. Tais resultados discordam de Borges et al. (1993). Para estes autores, entre 1978 e 1991, houve uma diminuição da área de mata e aumento da área de reflorestamento. Os autores argumentam que o problema está no fato da área de mata e 
reflorestamento serem relativamente pequenas, avaliado a pequena escala da imagem orbital de 1991, podem prejudicar a discriminação dos elementos (mata e reflorestamento).

A área urbana teve uma aumento de $7 \%$ de 1962 (2,6 ha) para 1995 (39,16 ha), o que pode ser devido a maior necessidade de mão-de-obra para o cultivo da cana-deaçúcar. Borges et al. (1993) também verificaram um aumento na área urbana no Município de Santa Bárbara D’Oeste, próximo às áreas com cana-de-açúcar.

Outro fato importante está associado à represa do Córrego do Ceveiro, que foi projetada para fornecer água potável para a Vila de Artemis, ocupava cerca de $0,6 \%$ da área ,(12 ha em 1978), devido a processos erosivos, foi assoreada e passou a ocupar $0,3 \%$ da área (6 ha em 1995), ou seja uma diminuição de $50 \%$. Hoje a represa do Córrego do Ceveiro se encontra desativada não mais fornecendo água para a vila.

Tabela 7 - Dimensão em ha, das áreas de uso da terra na Microbacia Hidrográfica do Ceveiro no período de 1962 - 1995.

\begin{tabular}{ccccc}
\hline & \multicolumn{4}{c}{ Ano/Escala } \\
\cline { 2 - 5 } Uso da Terra & $\mathbf{1 9 6 2}$ & $\mathbf{1 9 6 5}$ & $\mathbf{1 9 7 8}$ & $\mathbf{1 9 9 5}$ \\
& $\mathbf{1 : 2 5 . 0 0 0}$ & $\mathbf{1 : 6 0 . 0 0 0}$ & $\mathbf{1 : 3 5 . 0 0 0}$ & $\mathbf{1 : 2 5 . 0 0 0}$ \\
\hline Cana-de-açúcar & 318,24 & 151,68 & 524,48 & 1319,64 \\
Cultura anual & 633,44 & 835,72 & 226,64 & 2,96 \\
Pasto & 289,72 & 281,88 & 558,56 & 96,4 \\
Pasto Sujo & 288,92 & 247,28 & 282,2 & 181,24 \\
Reflorestamento & 283,6 & 230,88 & 267,96 & 120,12 \\
Mata & 45,08 & 32,4 & 31,24 & 134,08 \\
Mata ciliar & 126,92 & 202,24 & 76,24 & 91,28 \\
Área urbana & 2,6 & 8,32 & 11,44 & 39,16 \\
Cultura perene & 1,88 & 0 & 0 & 0 \\
Represa & 0 & 0 & 11,64 & 5,52 \\
\hline Total & 1990,4 & 1990,4 & 1990,4 & 1990,4 \\
\hline
\end{tabular}




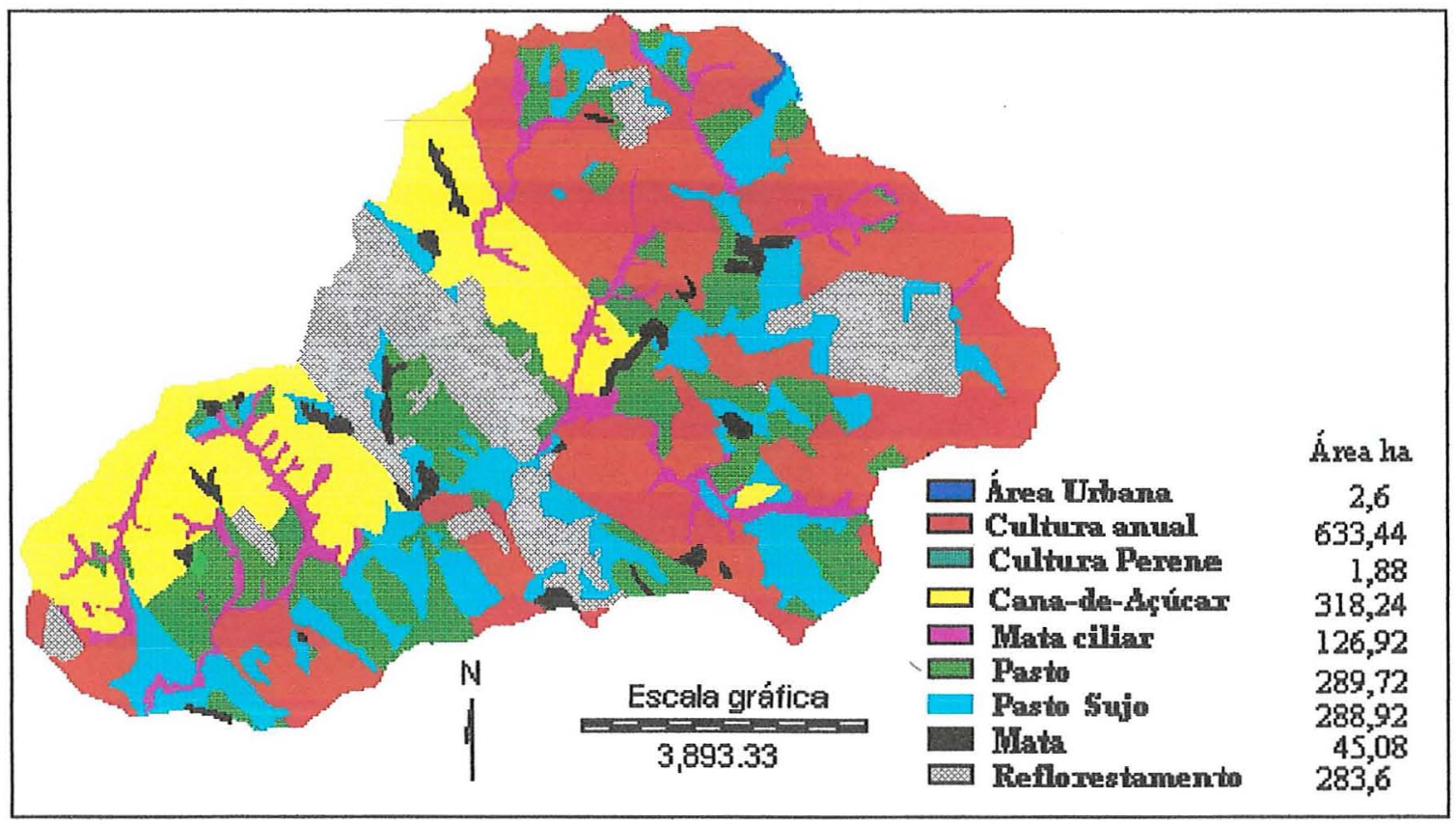

Figura 13 - Cenário do uso da terra na Microbacia Hidrográfica do Ceveiro em 1962.

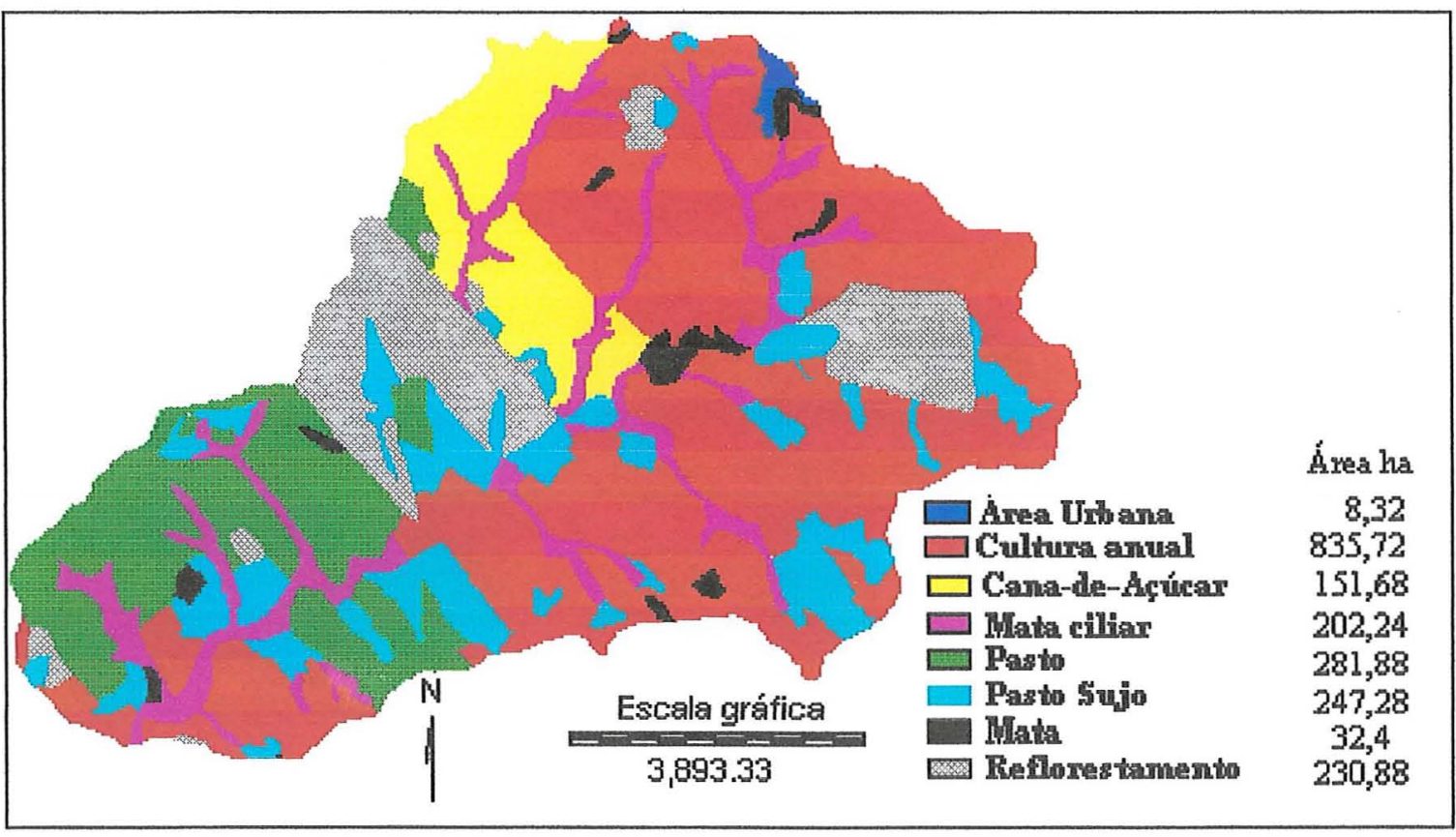

Figura 14 - Cenário do uso da terra na Microbacia Hidrográfica do Ceveiro em 1965. 


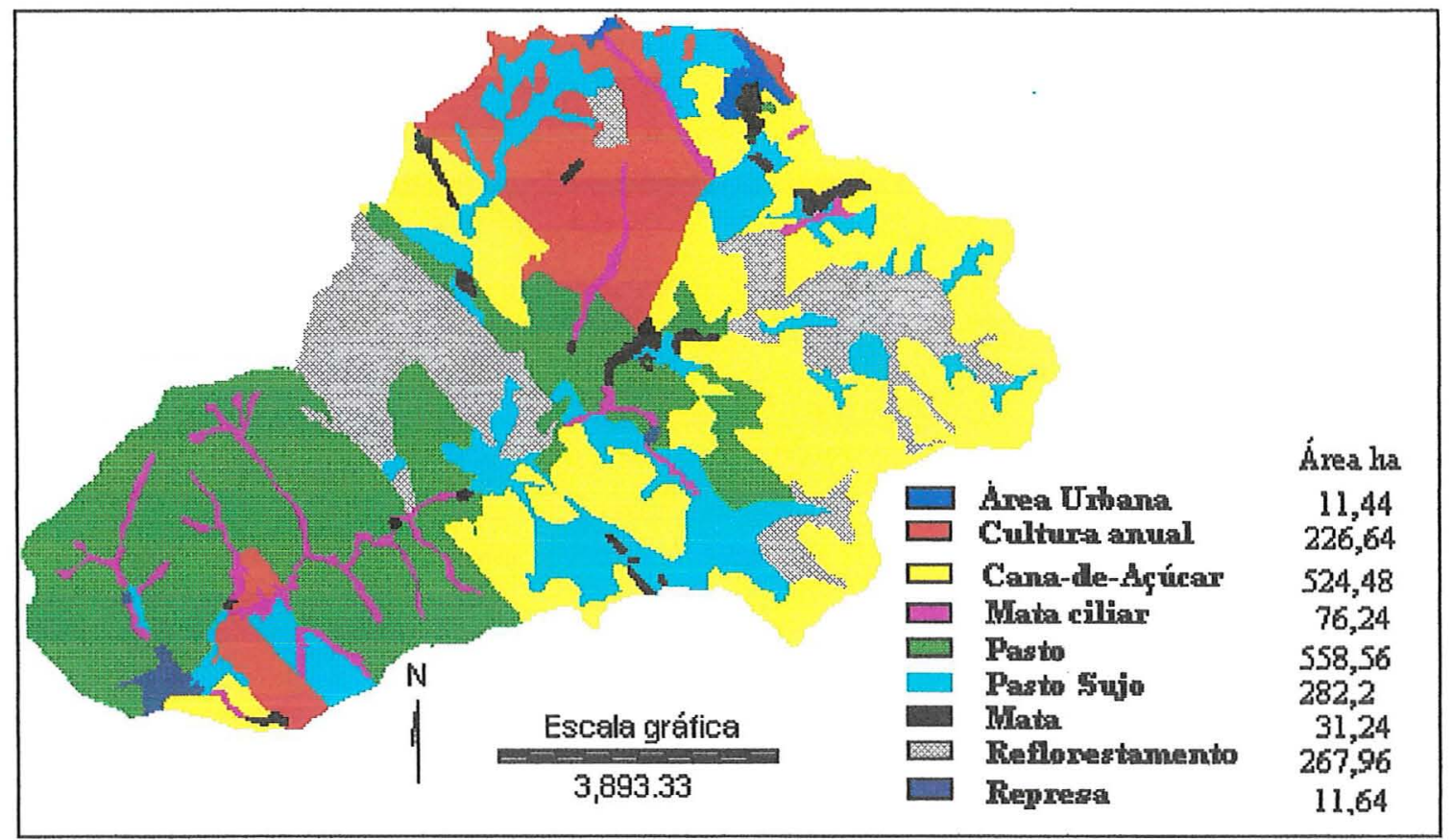

Figura 15 - Cenário do uso da terra na Microbacia Hidrográfica do Ceveiro em 1978.

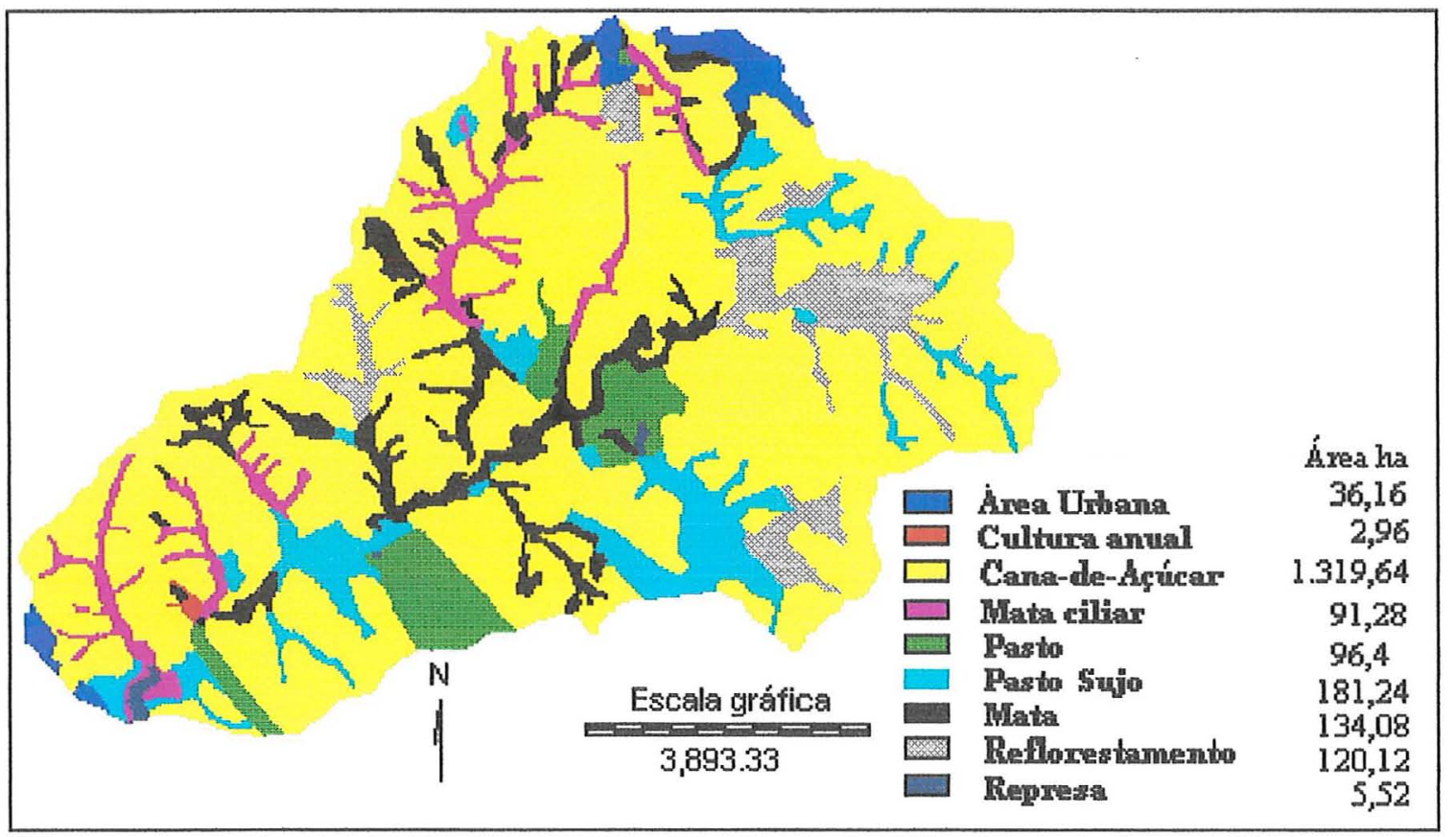

Figura 16 - Cenário do uso da terra na Microbacia Hidrográfica do Ceveiro em 1995. 


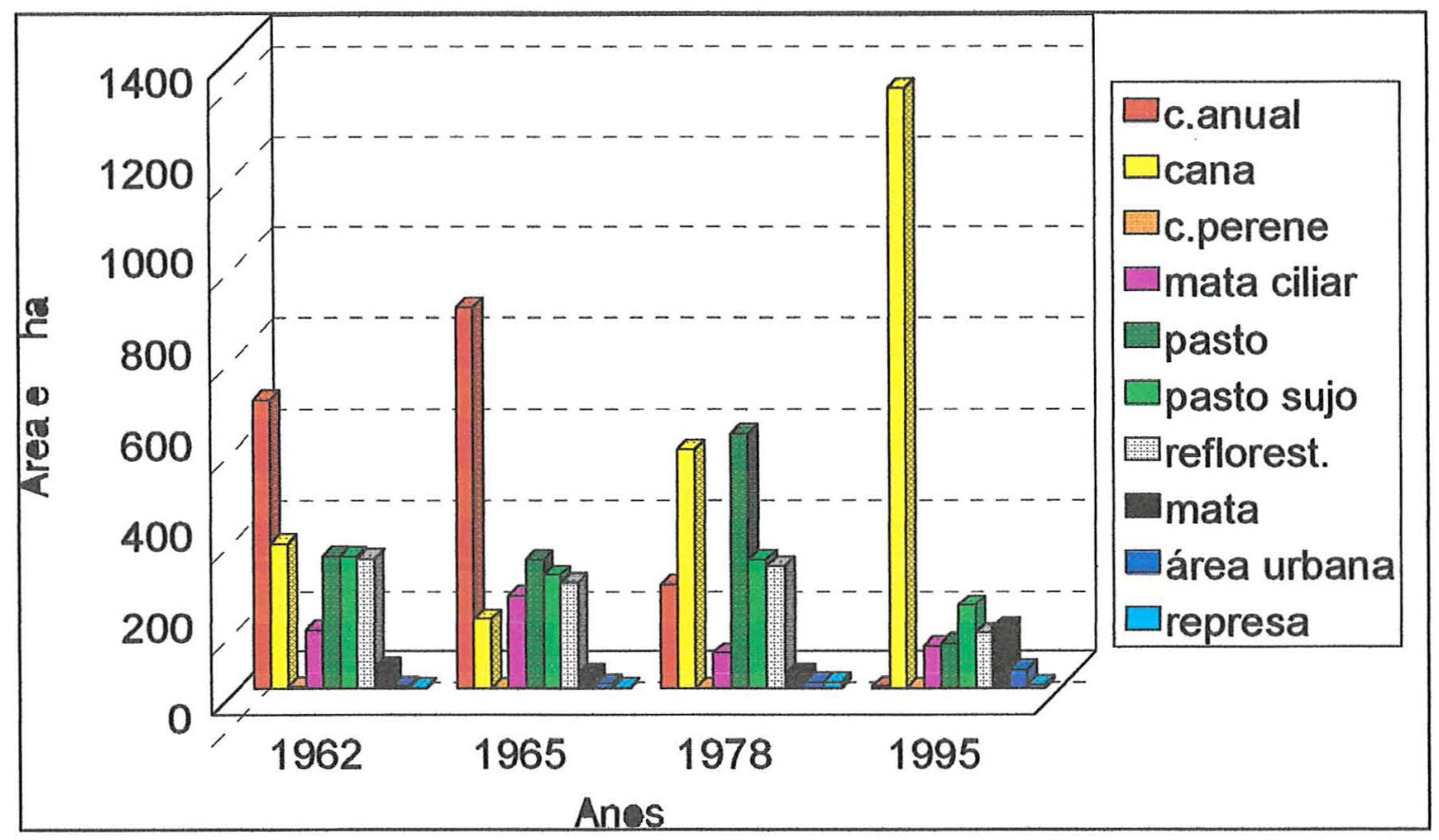

Figura 17 - Evolução do uso da terra na Microbacia Hidrográfica do Ceveiro em ha/ano

\subsubsection{Evolução das culturas na microbacia em função das classes de solo e declive}

Os valores em área para cada classe de solo e de declividade de acordo com a cultura são discutidos a seguir.

\subsubsection{Cultura anual}

A ocupação dos solos pelas culturas anuais pode ser observada no Figura 18, bem como suas respectivas áreas na Tabela 8 .

A maior parte das culturas anuais em 1962 ocupava principalmente os solos Litólicos (Li), com cerca de 330 ha, 54 \% da área. Já os solos com Horizonte B textural perfaziam um total de 258,8 ha, $42 \%$, sendo que o Podzólico Vermelho Amarelo (PV) era o solo mais representativo com 148 ha, $24 \%$ da área. Os $4 \%$ restantes estão 
divididos entre os Cambissolos $(\mathrm{Cb})$ com $1,8 \%$ e Hidromórficos mais solos Aluviais $(\mathrm{Hi}+\mathrm{Al})$ com $2,2 \%$ da área.

Em 1965, os solos Li ainda eram a principal classe de solo ocupada pela cultura com 433 ha, $53 \%$ da área. Os PV se mantiveram com $42 \%$ da área, sendo o restante dividido entre os outros solos. Em 1978 os solos Podzólicos predominavam com 122 ha, (56\% da área) sendo que os Li passaram a ocupar 87 ha (40\% da área). Em 1995 com a expansão da cana-de-açúcar, as culturas anuais passaram a ocupar apenas 2,9 ha (Tabela 7), com predomínio dos solos $\mathrm{Li}$, com $84 \%$ do total da área com cultura anual. O fato das culturas anuais estarem ocupando a maior parte da área de solos rasos entre 1962 e 1965 (Tabela 8), principalmente os $\mathrm{Li}$, deve-se ao fato do mesmo ser o de maior predominância na área de estudo com 903,16 ha (cerca de $45 \%$ da área).

As maiores áreas plantadas com cultura anual apresentaram declividades de 5 a $20 \%$ em todo o período do estudo (Figura 19 e Tabela 9 ). Cerca de $44 \%$ das culturas anuais (267,3 ha) em 1962, encontravam-se em áreas com declives de 10 a $20 \%$, e as classes de declives acima de $20 \%$ foram ocupadas em 33 ha que correspondem a $5 \%$ da MHC.

Em 1965, 336 ha de culturas anuais (41\% da área) apresentavam declives entre 10 e $20 \%$, e $5 \%$ da área plantada acima de $20 \%$ de declive. Observa-se que, apesar de um aumento das áreas plantadas com cultura anual, as proporções relacionadas com as declividades ocupadas se mantiveram constantes.

Assim sendo em 1978 e 1995, as culturas anuais permaneceram ocupando principalmente as áreas com declives entre 10 e $20 \%$.

$\mathrm{Em}$ todos os anos em estudo a cultura anual encontrou-se cultivada principalmente nos solos Litólicos e Podzólicos em declive ondulado, o que difere dos dados apresentados por Flores (1995), o qual considera que para esses solos em tais declives o uso mais adequado para reflorestamento e matas. 


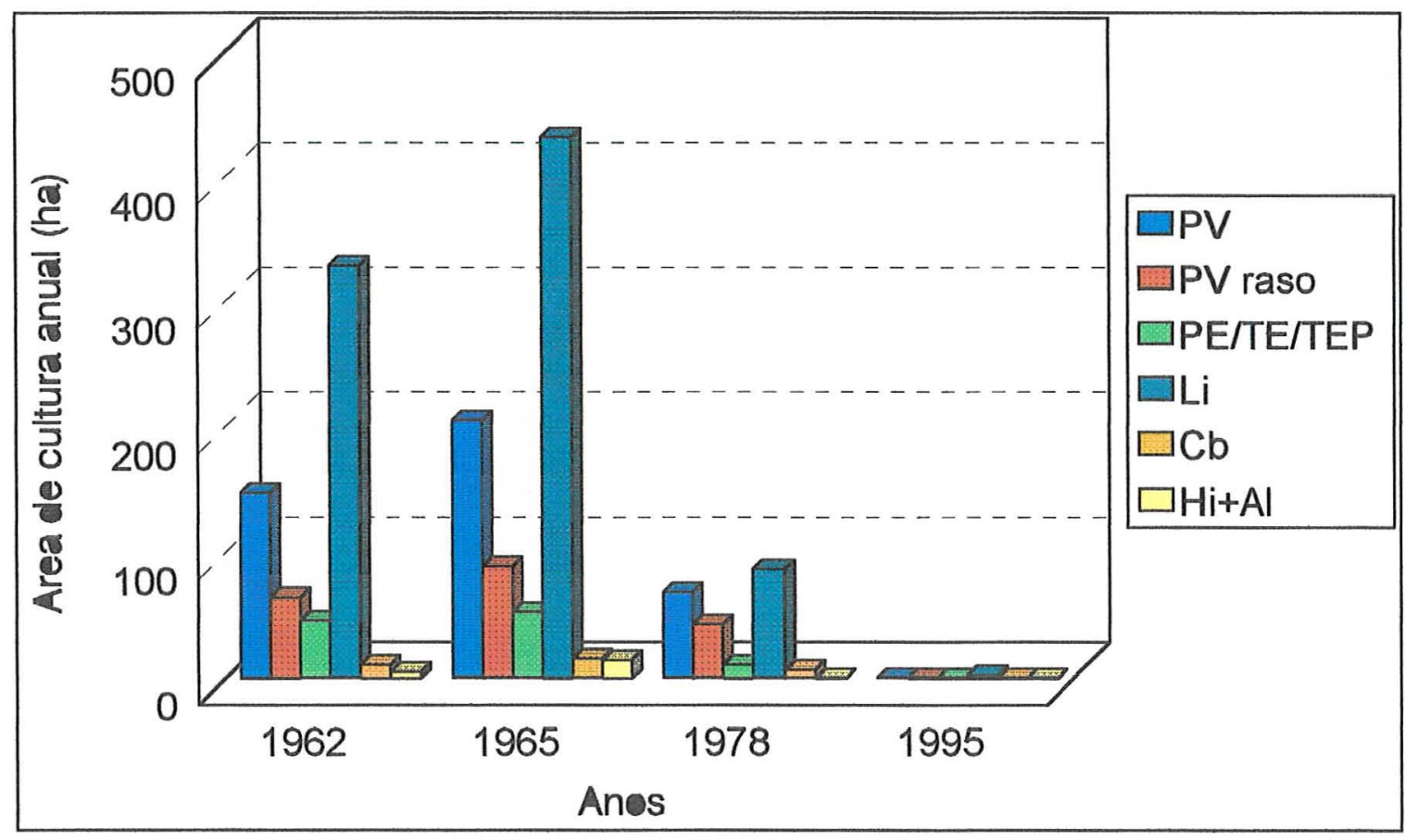

Figura 18 - Evolução das culturas anuais nos solos da área (ha).

Tabela 8 - Áreas em hectares de culturas anuais de acordo com os respectivos solos da área.

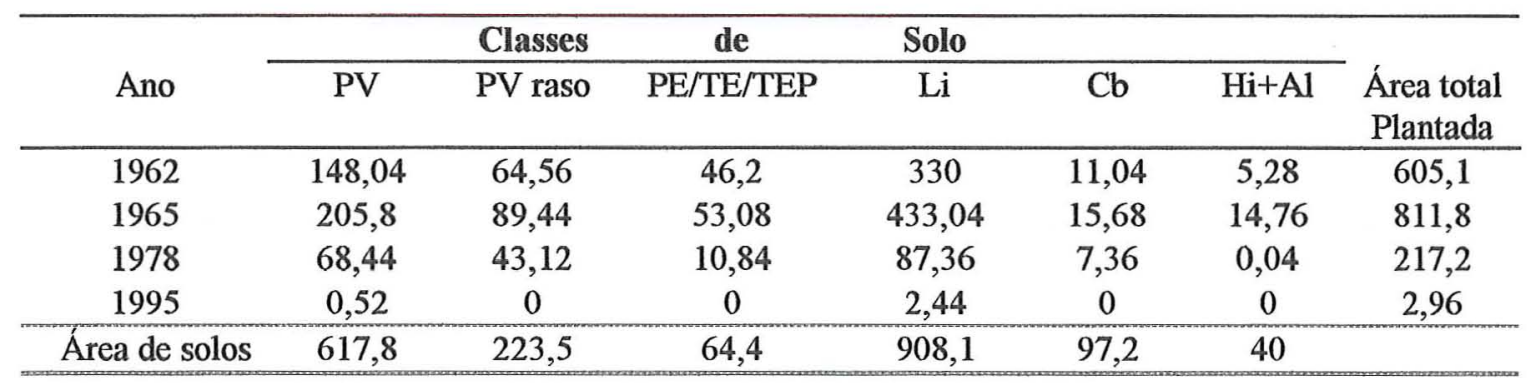




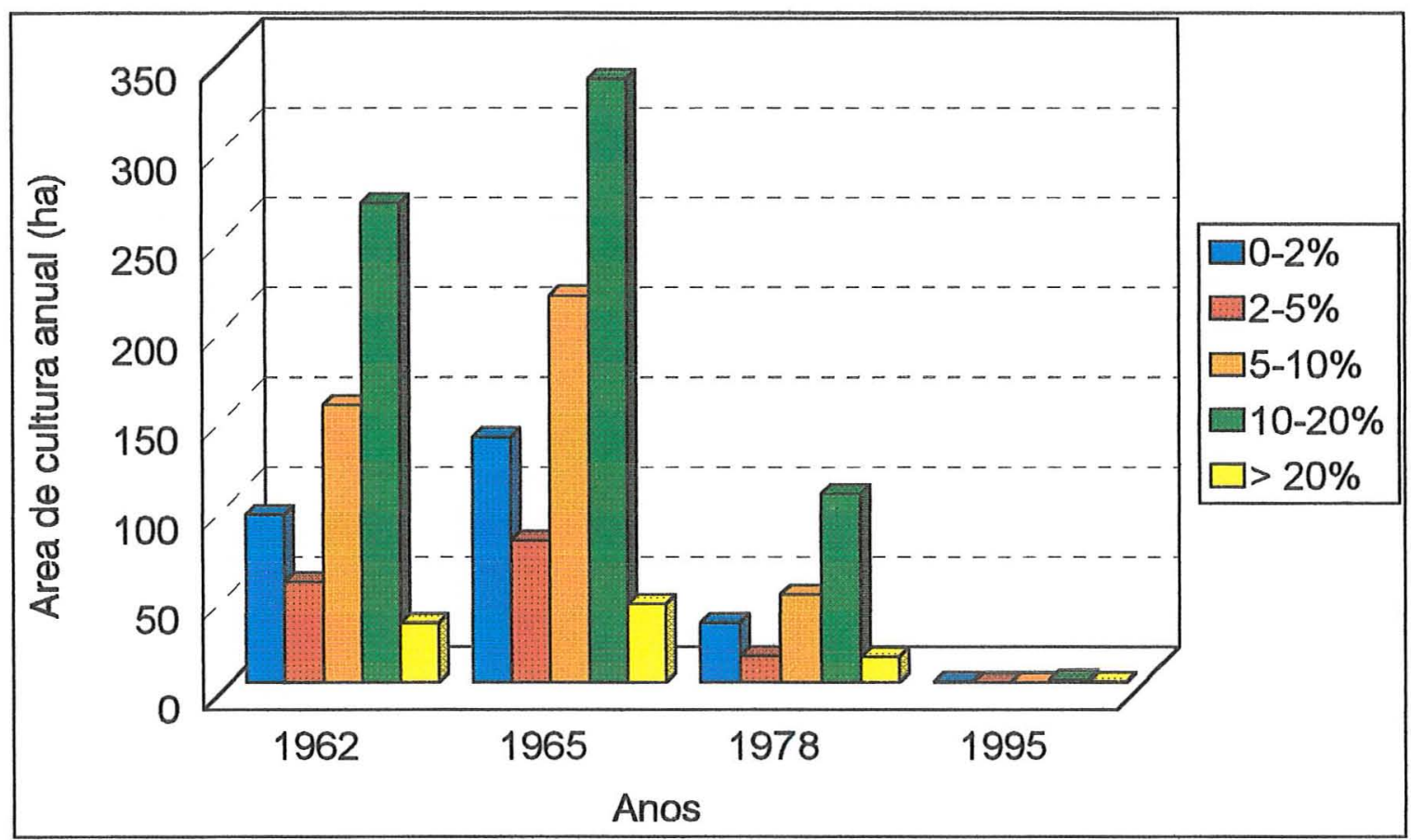

Figura 19 - Evolução das culturas anuais em suas respectivas classes de declive (ha).

Tabela 9 - Áreas em hectares de culturas anuais nas classes de declives.

\begin{tabular}{|c|c|c|c|c|c|c|}
\hline & & Classes & de & declive & & \\
\hline Ano & $0-2 \%$ & $2-5 \%$ & $5-10 \%$ & $10-20 \%$ & $>20 \%$ & $\begin{array}{c}\text { Área total } \\
\text { plantada }\end{array}$ \\
\hline 1962 & 93,64 & 56,08 & 154,92 & 267,24 & 33,24 & 605,12 \\
\hline 1965 & 136,48 & 79,36 & 215,56 & 336,4 & 44 & 811,8 \\
\hline 1978 & 33,2 & 14,8 & 49,36 & 105,36 & 14,44 & 217,16 \\
\hline 1995 & 0,68 & 0 & 0,12 & 1,6 & 0,56 & 2,96 \\
\hline $\begin{array}{c}\text { Área das classes de } \\
\text { declive }\end{array}$ & 339 & 154 & 470 & 858 & 130 & \\
\hline
\end{tabular}




\subsubsection{Cana-de-açúcar}

Os solos que mais contribuíram em termos de área, para o plantio da cana-deaçúcar, foram os solos Podzólicos e Litólicos (Figura 20). Em 1962 a área plantada com cana-de-açúcar no Podzólico Vermelho Amarelo (PV) era de 191,08 ha o que representava $60 \%$ da área total plantada (Tabela 10).

Em 1995 com a expansão da cana-de-açúcar, a mesma apresentava-se com 507 ha com o solo PV, correspondendo a $38 \%$ do total da área plantada e $82 \%$ do total de Podzólicos Vermelho Amarelo na MHC (Tabela 10).

Os solos Li em 1962 ocupavam 66,5 ha cerca de $21 \%$ da área com a cultura onde em 1995, a área plantada nessa classe de solo aumentou cerca de 8 vezes, passando para 530 ha quando comparado a 1962 , ocupando $40 \%$ da área total com a cultura e $58 \%$ do total dessa classes de solo (Tabela 10). É interessante se notar que o solo PV em 1962 era o mais utilizado pela cana-de-açúcar, onde a partir de 1978 verificou-se um aumento nas áreas cultivadas com os solos Li (Figura 20 ). Isso se deveu, principalmente, a necessidade de áreas para o plantio da cana-de-açúcar, pois com o Proalcool, a cana na área de estudo em 1978, ocupou o lugar de outros usos da terra. O fato é que os solos Li ocupam a maior parte da área e estão mais próximos a usina de processamento, por conseqüência passou-se explorá-los, concordando com Sparovek \& Lepsch (1995), que consideram essas áreas restritas ao plantio de cana-de-açúcar, apesar de ainda serem utilizadas.

Em todos os anos em estudo, a cana-de-açúcar ocupou principalmente áreas com declividades entre 5 e $20 \%$ (Figura 21). Em 1962 a cultura predominava em declives de 10 a $20 \%$ (149 ha), $47 \%$ da área total ( 318 ha) e $17 \%$ do total dessa classe de declive (858 ha), conforme a Tabela 11. As áreas com declives de 10-20\% também predominaram em 1995, sendo que estes ocupavam uma área com a cultura de 588,5 ha, cerca de $44 \%$ do total plantado (1.319,6 ha) e $68 \%$ do total dessa classe de declive.

Do total das áreas com declives entre 5 e $10 \%$ (470 ha), $15 \%$ era ocupada por cana-de-açúcar, sendo que do total de área com a cultura na época ( $318 \mathrm{ha})$ essa classe 
representava $22 \%$ (Tabela 11). Em 1995, cerca de $75 \%$ do total da classe de 5 a $10 \%$ era ocupada por cana-de-açúcar, sendo que do total de área plantada $(1.319,6 \mathrm{ha})$, a classe representava $27 \%$.

As classes de declive entre 0 e $2 \%$ tiveram um aumento considerável com a canade-açúcar, sendo que em 1962 ocupavam 52 ha, cerca de $16 \%$ do total com a cultura (318 ha) e cerca de $15 \%$ do total dessa classe na MHC (339 ha). Em 1995 a mesma ocupava 188,7 ha, $14 \%$ do total plantado $(1.319,7$ ha) e $55 \%$ do total (Tabela 11$)$, concordando com Flores (1995) que considera adequada a utilização de solos Litólicos e Podzólicos em declives suaves.

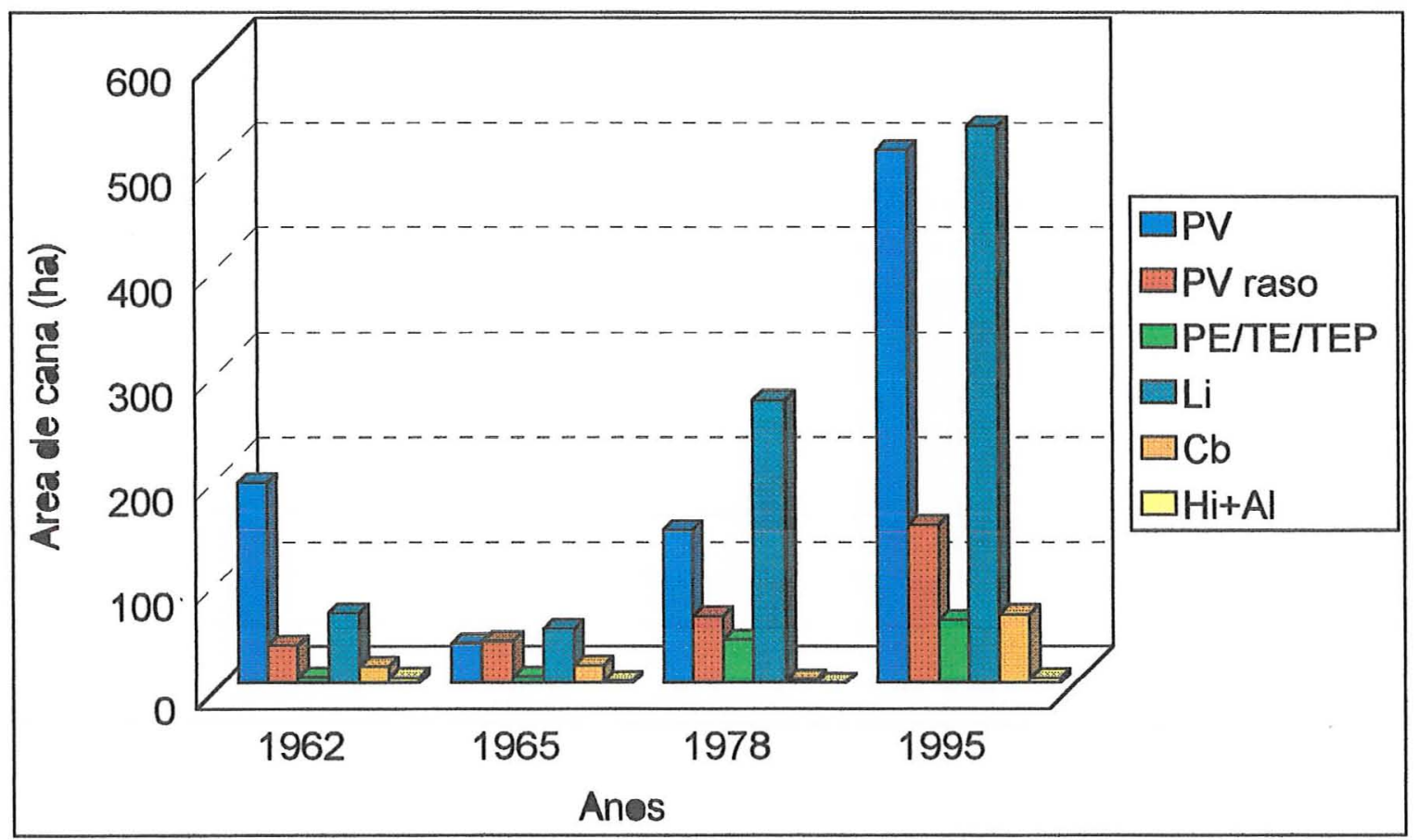

Figura 20 - Evolução da cana-de-açúcar, nos solos da área (ha).

Tabela 10 - Áreas em hectares de cana-de-açúcar nos solos.

\begin{tabular}{cccccccc}
\hline & \multicolumn{3}{c}{ Classes } & de & Solo & & \\
\cline { 2 - 6 } Ano & PV & PV raso & PE/TE/TEP & Li & Cb & Hi+Al & $\begin{array}{c}\text { Área total } \\
\text { Plantada }\end{array}$ \\
\hline 1962 & 191,08 & 35,64 & 5,24 & 66,56 & 15,08 & 4,64 & 318,24 \\
1965 & 36,68 & 39,16 & 5,96 & 51,48 & 15,96 & 1,48 & 150,72 \\
1978 & 145,84 & 63,64 & 40,96 & 270 & 2,44 & 0 & 522,88 \\
1995 & 507,8 & 150,92 & 60 & 530,92 & 65,44 & 4,56 & 1319,64 \\
\hline Área de Solos & 617,8 & 223,5 & 64,4 & 908,1 & 97,2 & 40 & \\
\hline
\end{tabular}




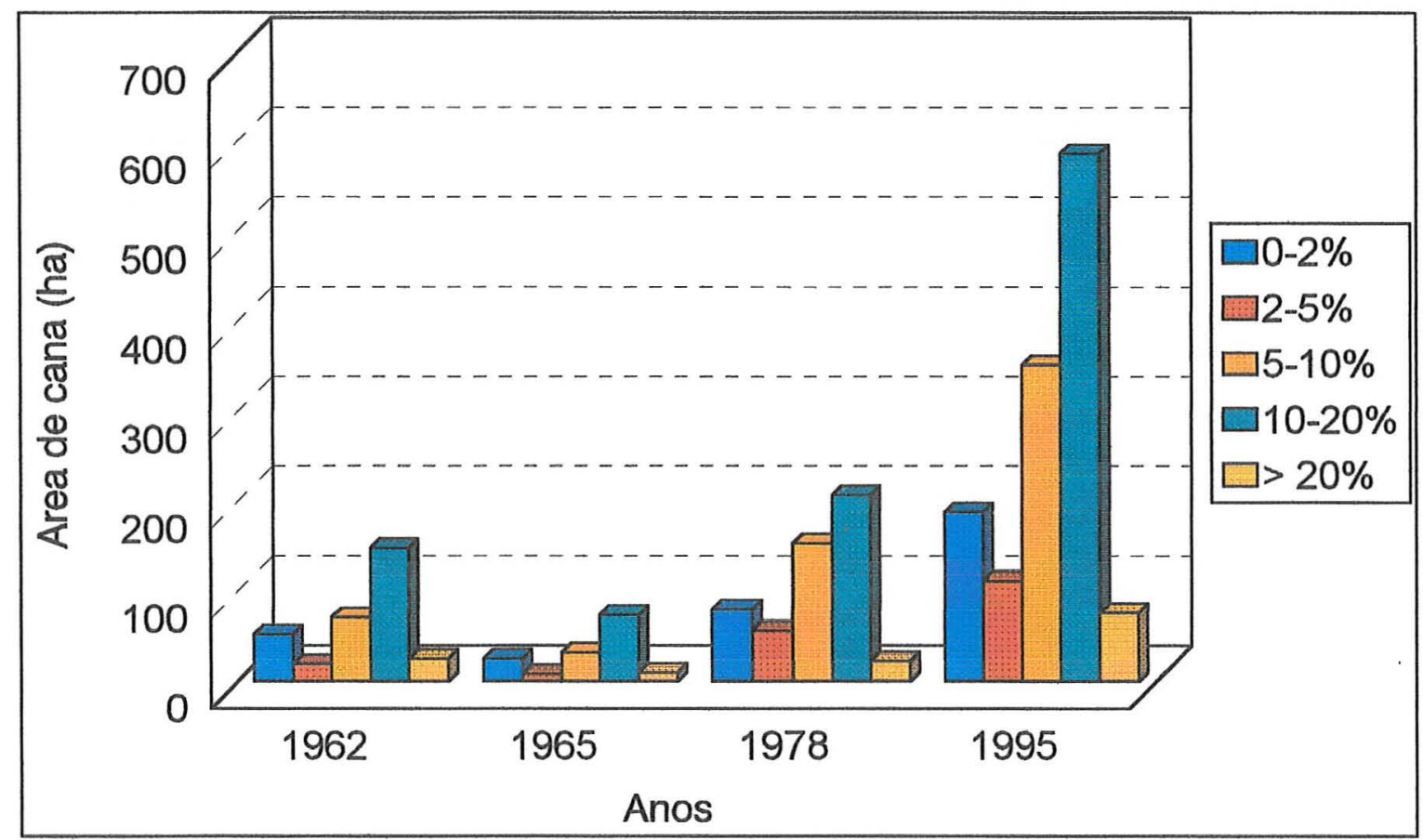

Figura 21 - Evolução da cana-de-açúcar em suas respectivas classes de declive (ha).

Tabela 11 - Áreas em hectares de cana-de-açúcar nas classes de declive.

\begin{tabular}{ccccccc}
\hline & \multicolumn{3}{c}{ Classes } & de & declive & \\
\cline { 2 - 6 } Ano & $0-2 \%$ & $2-5 \%$ & $5-10 \%$ & $10-20 \%$ & $>20 \%$ & $\begin{array}{c}\text { Área total } \\
\text { plantada }\end{array}$ \\
\hline 1962 & 52,4 & 19,76 & 71,6 & 149,2 & 25,28 & 318,24 \\
1965 & 25,56 & 8,16 & 32,2 & 74,56 & 10,24 & 150,72 \\
1978 & 80,6 & 56,88 & 154,56 & 207,92 & 22,92 & 522,88 \\
1995 & 188,76 & 112,08 & 353,24 & 588,52 & 77,04 & 1319,64 \\
\hline $\begin{array}{c}\text { Areas das classes de } \\
\text { declive }\end{array}$ & 339 & 154 & 470 & 858 & 130 & 1951 \\
\hline
\end{tabular}




\subsubsection{Pastagens}

Os principais solos ocupados pelas pastagens nos anos em estudo, foram os Podzólico Vermelho Amarelo (PV) e os solos Litólicos (Li) (Figura 22).

As áreas de pastagem encontravam-se cultivadas em 1962, principalmente sobre os solos com horizonte B textural (PV, PV raso e PE/TE/TEP) que perfazem um total de 234,7 ha (cerca de $56 \%$ da área). Dentre tais solos o PV apresentava-se com 139 ha, ( $33 \%$ do total da área com pasto). Os solos Li foram ocupados com 129,6 ha , $31 \%$ do total com pastagem (Figura 22).

Em 1965, as áreas com pastagens sobre o PV, apresentavam-se com 238,8 ha, ou seja $45 \%$ do total de pasto. As áreas com Li, apresentavam-se com 192 ha, $36 \%$ do total de pastagens (Tabela 12).

O solo PV, em 1978 perfazia 288,7 ha, (38\% do total) e $47 \%$ da área total de PV. Neste ano, o solo Li passou a ser o principal solo com pastagem, ou seja 351 ha, ( $46 \%$ ) e $38 \%$ do total desse solo.

Em 1995 apenas 20 ha do solo PV era ocupado por pastagens, ou seja $7 \%$ do total das áreas e $3 \%$ do total de $\mathrm{PV}$. Os solos $\mathrm{Li}$, mantiveram-se como os principais solos sob pastagem, com 184,3 ha, (66\% do total de pastagens) e $20 \%$ do total de $\mathrm{Li}$ (Tabela 12 e Figura 22).

Isso demonstra que os pastos se mantiveram nos solos Litólicos onde normalmente são cultivados. Essa constatação pode ser também observada em relação aos solos Hidromórficos e Aluviais (Hi+Al), que praticamente não alteraram o uso com pasto de 1962 a 1995, o que está de acordo com Flores (1995). O valor baixo 8,12 ha de pastagem em 1965, deve estar relacionado a perda do detalhamento provocado pela escala 1:60.000, concordando com Borges et al. (1993).

As principais classes de declive ocupadas por pastagens podem ser citadas em ordem decrescente com relação a sua utilização de $10-20 \%$; $5-10 \%$ e $0-2 \%$ para todos os anos em estudo (Figura 23). O que é justificado por essa cultura normalmente é colocada em áreas de maior declividade, com exceção das áreas com solos $\mathrm{Hi}+\mathrm{Al}$, 
enquanto que menores declividades são usadas para outras culturas, como por exemplo, as anuais.

Do total das áreas com declives de 10 a $20 \%$ ( 858 ha), 237 ha cerca de $27 \%$ do total dessa classe de declive eram ocupados por pastagens em 1962, perfazendo $41 \%$ do total da área de pasto (572,8 ha), conforme Tabela 13. Em 1965, as pastagens ocupavam 233 ha, $44 \%$ o que correspondia a $27 \%$ do total dessa classe de declive, em 1978 cerca de 364 ha, $42 \%$ eram ocupados por pastos correspondendo a $42 \%$ do total dessa classe de declive. Em 1995 a área de 113,7 ha era utilizadas por pastagens.

A classe de declive de 5 a $10 \%$, apresentavam uma área total na MHC de 470 ha, sendo 139 ha em 1962, $24 \%$ eram ocupados por pastagens e correspondiam a $29 \%$ do total dessa classe de declive, e em 1965 essas áreas não apresentaram grandes mudanças (Figura 23). Em 1978, cerca de 185,5 ha (22\% do total de pastagens) ocupavam classes de declive de 5 a $10 \%$ e em 1995 apenas 61 ha (22\% da área total com pastagem).

As classes de declive entre 0 e $2 \%$ perfazem um total de 339 ha na MHC, sendo que em 1978 essa classe de declive passou a ocupar 155,7 ha, cerca de $46 \%$ do total dessa classe de declive e $19 \%$ da área total com pastagens ( 824 ha). Em 1995 as pastagens ocupavam 60,44 ha com classes de declive de 0 a $2 \%$, o que corresponde a $18 \%$ do total dessa classe ( $339 \mathrm{ha}$ ) e $22 \%$ da área com pasto. 


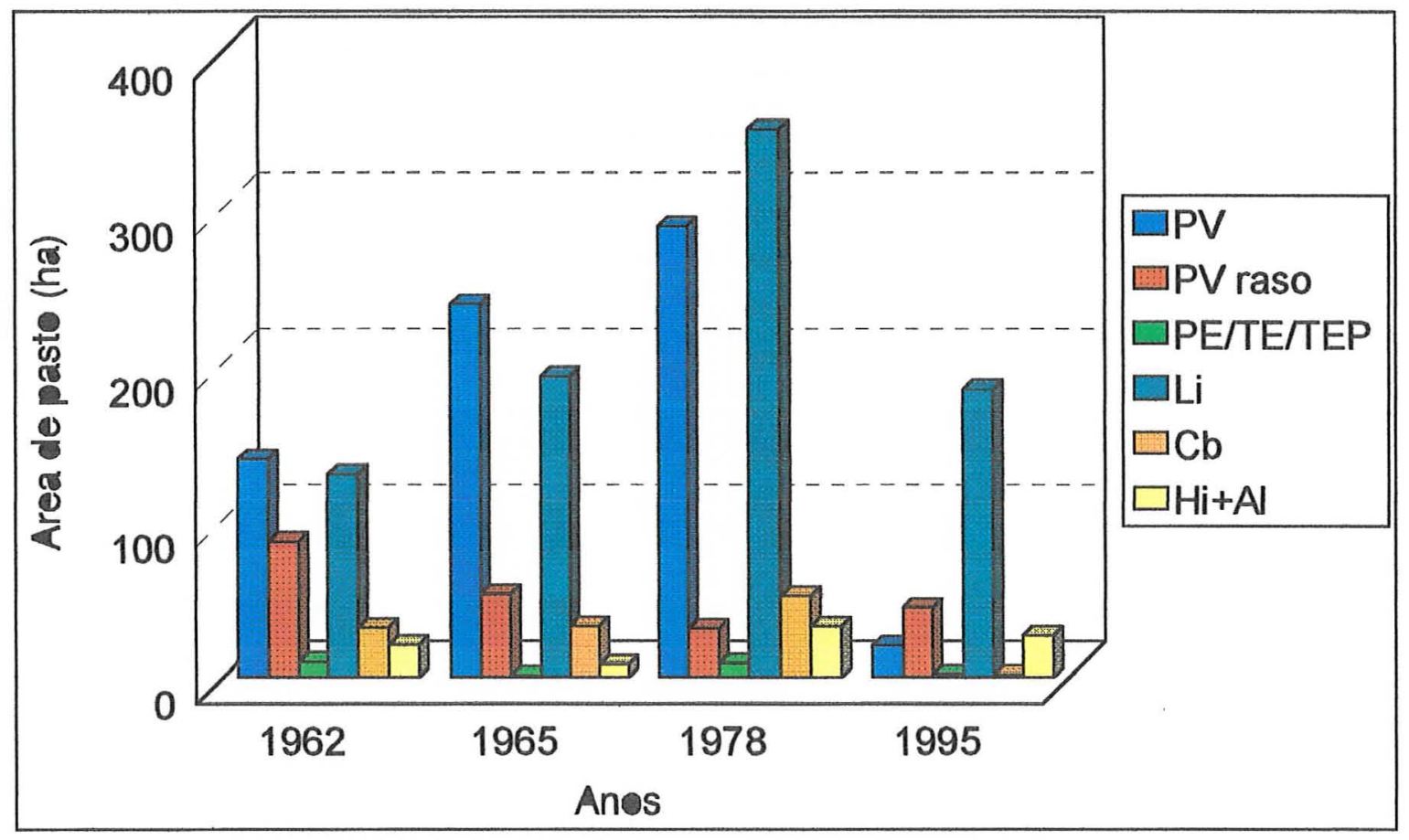

Figura 22 - Evolução das pastagens nos solos da área (ha).

Tabela 12 - Áreas em hectares de pastagens nos solos.

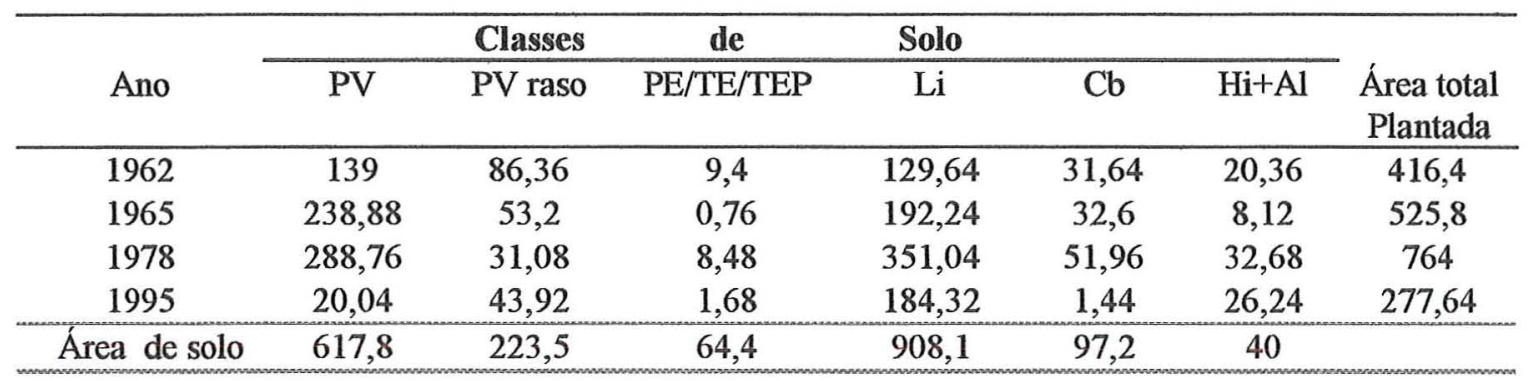




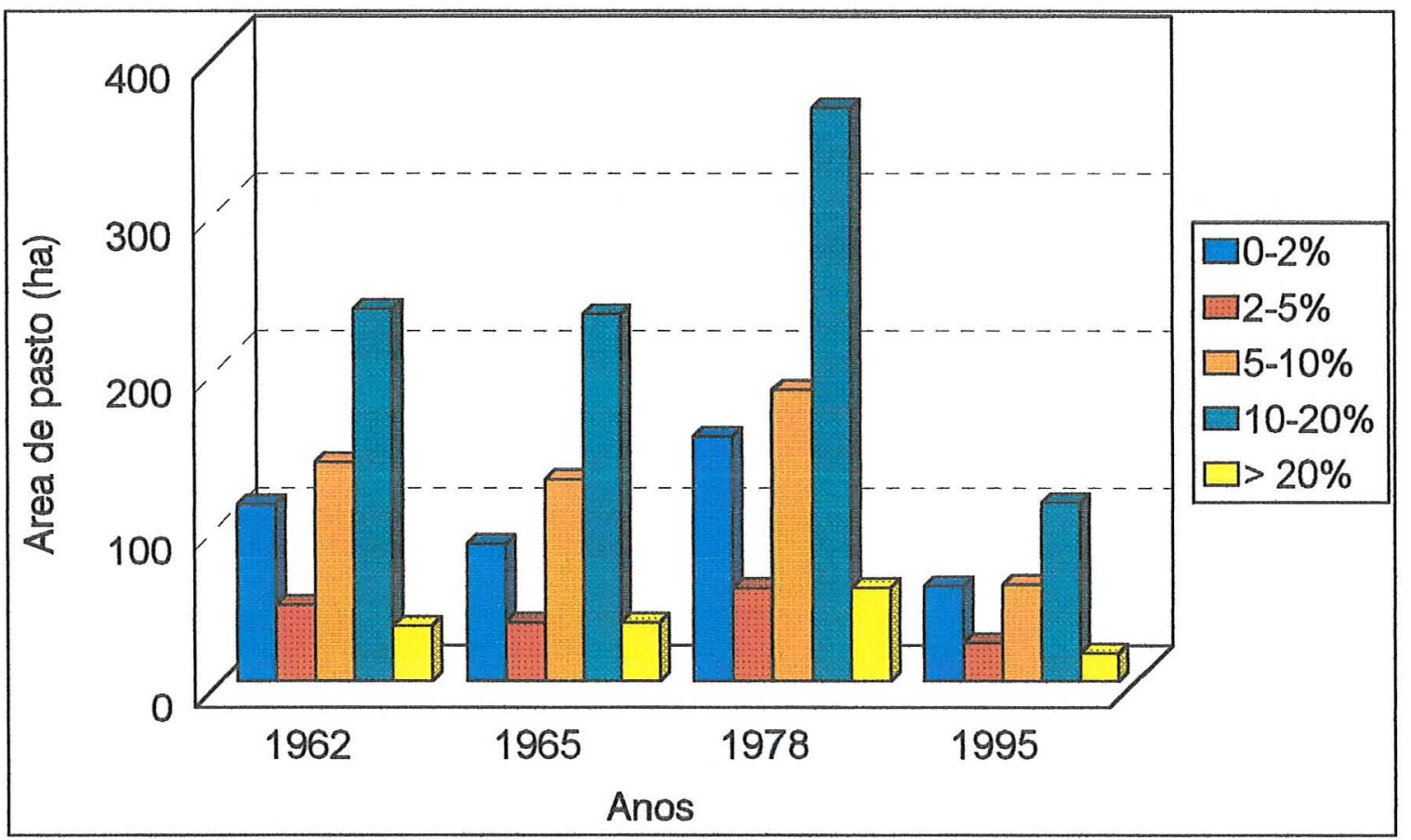

Figura 23 - Evolução das pastagens em suas respectivas classes de declive (ha).

Tabela 13 - Áreas em hectares das pastagens nas classes de declive.

\begin{tabular}{|c|c|c|c|c|c|c|}
\hline & & Classes & de & declive & & \\
\hline Ano & $0-2 \%$ & $2-5 \%$ & $5-10 \%$ & $10-20 \%$ & $>20 \%$ & $\begin{array}{l}\text { Área total } \\
\text { plantada }\end{array}$ \\
\hline 1962 & 112,6 & 48,8 & 139,44 & 237,04 & 35 & 572,88 \\
\hline 1965 & 87,32 & 37,36 & 128,64 & 233,64 & 37,04 & 524 \\
\hline 1978 & 155,76 & 59,24 & 185,52 & 364,24 & 59,64 & 824,4 \\
\hline 1995 & 60,44 & 24,28 & 61,68 & 113,72 & 17,92 & 278,04 \\
\hline $\begin{array}{c}\text { Área das classes } \\
\text { de declive }\end{array}$ & 339 & 154 & 470 & 858 & 130 & \\
\hline
\end{tabular}




\subsubsection{Reflorestamento}

Os solos que predominaram na MHC, durante todos os anos de estudo, com ocupação de reflorestamento, foram o solos Litólicos (Li) e o solo Podzólico Vermelho Amarelo (PV) (Figura 24).

O reflorestamento em 1962 ocupava uma área de 280 ha, sendo 132,4 ha, (47\% da área total), plantado sobre solo $\mathrm{Li}$, correspondendo a $14 \%$ dessa classe de solo. $\mathrm{O}$ solo PV, apresentava-se com 93,3 ha, (33\% do total) e $15 \%$ da área total desse solo. Os $20 \%$ restantes da área de reflorestamento se encontravam sobre Podzólico Vermelho Amarelo raso (PV raso) em $9 \%$ da área e Cambissolos (Cb) em $11 \%$ da área (Tabela 14).

Em 1965 o reflorestamento ocupava uma área de 229,8 ha dos quais 92 ha, cerca de $40 \%$ da área utilizada com PV, correspondendo a $15 \%$ do total do solo PV na MHC. Os solos Litólicos ocupavam 90 ha, $39 \%$ do total de reflorestamento, $10 \%$ do total dessa classe de solo na área. Dos $21 \%$ restantes, o Cambissolos $(\mathrm{Cb})$ corresponde a $12 \%$ e o solo PV raso englobava $9 \%$ do total (Tabela 14).

Do total do reflorestamento em 1978 (267,9 ha), os solos Li correspondiam a 50 $\%$ das áreas plantadas e $15 \%$ dessa classe de solo. O PV ocupava $32 \%$ do total de reflorestamento e $14 \%$ do total desse solo. Dos $18 \%$ restantes das áreas com reflorestamento, $12 \%$ eram ocupados pelo Cambissolos $(\mathrm{Cb})$ e $6 \%$ pelo solo $\mathrm{PV}$ raso.

Em 1995 o reflorestamento ocupava 120 ha, dos quais 79,2 ha (cerca de $66 \%$ do total da cultura) com os solos Li correspondendo a $6 \%$ do total da classe desse solo. $\mathrm{O}$ solo PV era representado por 27,2 ha (23\% do total da cultura) e apenas $4 \%$ desse solo. Dos $11 \%$ restantes da área plantada $8 \%$ sobre PV raso e $3 \%$ sobre $\mathrm{Cb}$ (Tabela 14 ).

Os intervalos de declive entre 5 a $20 \%$, predominaram com reflorestamento, sendo que o intervalo de 0 a $2 \%$ também teve um uso significativo quando comparado aos demais (Figura 25).

Dos 339 ha com declives de 0 a $2 \%$, em 1962 cerca de 45 ha, $13 \%$ dessa classe de declive era ocupada, correspondendo a $16 \%$ do total de reflorestamento (280 ha). 
Nos anos de 1965 e 1978 não ocorreram grandes alterações, correspondendo a cerca de 11 a $13 \%$ do total dessa classe. Em 1995 apenas 19,6 ha ou seja, $16 \%$ das áreas com reflorestamento se encontravam sobre essa classe de declive (Tabela 15).

É interessante observar que o reflorestamento praticamente não ocupou as áreas dos solos mais férteis da MHC, no agrupamento de solos PE/TE/TEP (Tabela 14), mantendo-se principalmente naqueles menos profundos, principalmente os solos Litólicos, concordando com Flores (1995).

As áreas com 5 a $10 \%$ de declive ocupam 470 ha ao todo, sendo que dos 72 ha em 1962, $26 \%$ eram ocupadas por reflorestamentos, correspondendo a $15 \%$ dessa classe, em 1965, ocupava 53,8ha ( $23 \%$ da área com a cultura) e $11 \%$ do total da classe. Em 1978, a área de reflorestamento nessa classe de declive era de 58 ha, cerca de $22 \%$ da área plantada e $12 \%$ do total da classe, e em 1995 apenas 20,5 ha ( $4 \%$ da classe) eram ocupados com a cultura, a qual correspondia a $17 \%$ do total.

Como pode ser observado pelo Figura 25 , o intervalo de declividade de 10 a $20 \%$ foi o mais utilizado em todos os anos, sendo que o mesmo na maior área na MHC (858 ha) o que está de acordo com Flores (1995) que considera mais adequado o reflorestamento em áreas mais declivosas. Dessa forma, em 1962 as áreas com reflorestamento e intervalo de declive entre 10 a $20 \%$ perfaziam um total de 125,3 ha (44\% do total da cultura e $15 \%$ do total da classe) (Tabela 15). Em 1965, ocorreram 108,9 ha, com a referida classe de declive ( $47 \%$ do total da cultura e $13 \%$ do total da classe). Em 1978 os valores não deferiram muito dos valores citados para 1962. Em $1995,59,8$ ha que correspondia a $50 \%$ do total da cultura e apenas $7 \%$ do total da classe. 


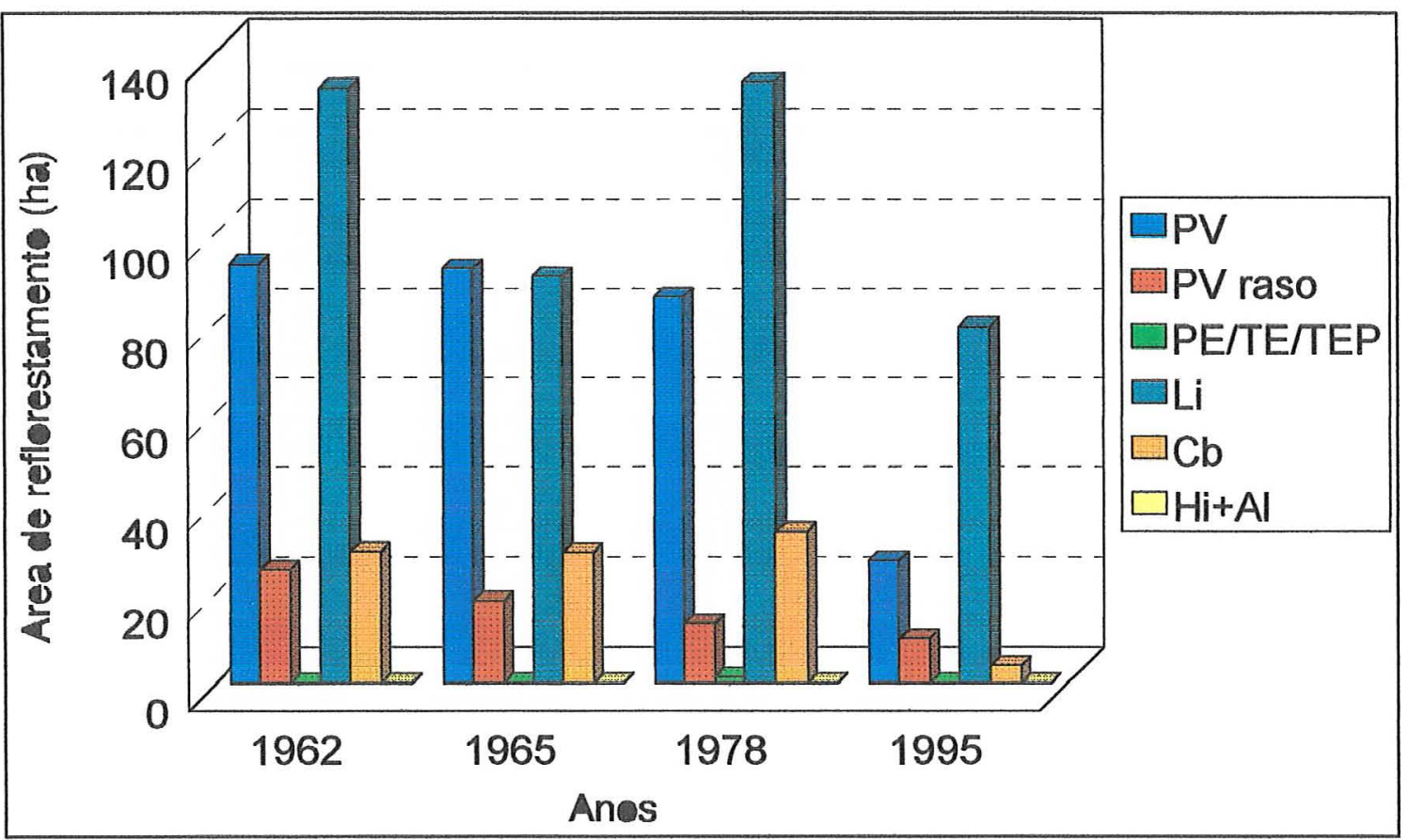

Figura 24 - Evolução do reflorestamento nos solos (ha).

Tabela 14 - Áreas em hectares de reflorestamento nos solos.

\begin{tabular}{cccccccc}
\hline & \multicolumn{1}{c}{ Classes } & de & Solo & & \\
\cline { 2 - 6 } Ano & PV & PV raso & PE/TE/TEP & Li & Cb & Hi+Al & $\begin{array}{c}\text { Área total } \\
\text { Plantada }\end{array}$ \\
\hline 1962 & 93,36 & 25,12 & 0 & 132,4 & 29,24 & 0,08 & 280,2 \\
1965 & 92,2 & 18,2 & 0 & 90,44 & 29 & 0 & 229,84 \\
1978 & 85,92 & 13,16 & 1,4 & 133,88 & 33,56 & 0,04 & 267,96 \\
1995 & 27,28 & 9,76 & 0 & 79,24 & 3,84 & 0 & 120,12 \\
\hline $\begin{array}{c}\text { Area total dos } \\
\text { solo }\end{array}$ & 617,8 & 223,5 & 64,4 & 908,1 & 97,2 & 40 & \\
\hline
\end{tabular}




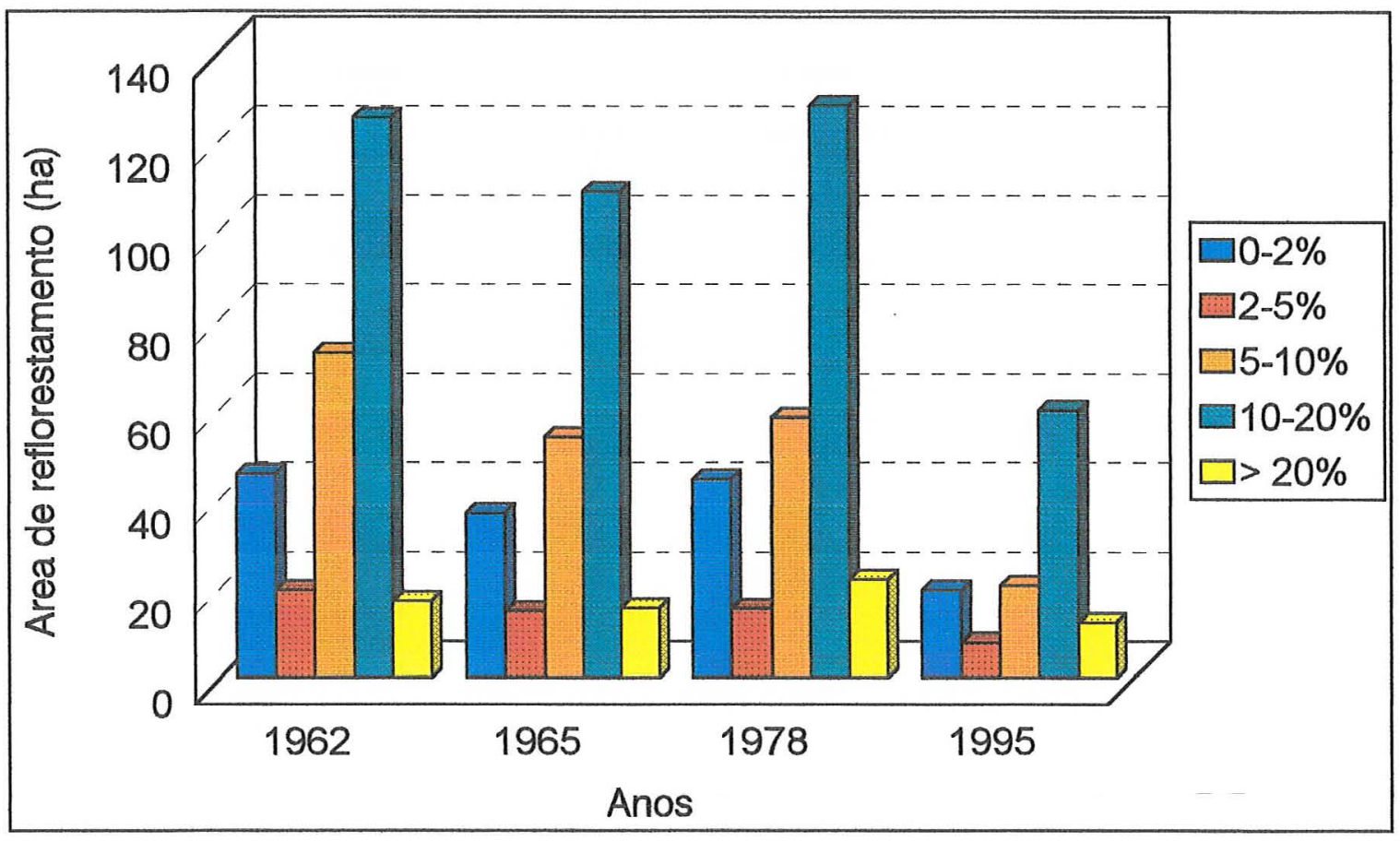

Figura 25 - Evolução do reflorestamento em suas respectivas classes de declive (ha).

Tabela 15 - Áreas em hectares de reflorestamento nas classes de declive.

\begin{tabular}{|c|c|c|c|c|c|c|}
\hline & & Classes & de & declive & & \\
\hline Ano & $0-2 \%$ & $2-5 \%$ & $5-10 \%$ & $10-20 \%$ & $>20 \%$ & $\begin{array}{l}\text { Área total } \\
\text { plantada }\end{array}$ \\
\hline 1962 & 45,48 & 19,6 & 72,72 & 125,32 & 17,08 & 280,2 \\
\hline 1965 & 36,76 & 14,76 & 53,84 & 108,96 & 15,52 & 229,84 \\
\hline 1978 & 44,28 & 15,44 & 58,08 & 128,16 & 22,0 & 267,96 \\
\hline 1995 & 19,6 & 7,84 & 20,56 & 59,8 & 12,32 & 120,12 \\
\hline $\begin{array}{l}\text { Area das classes } \\
\text { de declive }\end{array}$ & 339 & 154 & 470 & 858 & 130 & \\
\hline
\end{tabular}




\subsubsection{Mata nativa}

Os principais solos ocupados por mata, em todos os anos, foram os Litólicos (Li) e os solos Podzólicos Vermelho Amarelo (PV) (Figura 26), que são altamente susceptíveis a erosão e apresentam-se segundo Flores (1995) como adequados para áreas de preservação, quando em declives acentuados.

Os solos Li perfazem um total de 908,1 ha. Em 1962 apresentavam uma área com mata de 16 ha (1,8\% da área desse solo e $36 \%$ do total das matas), e em 1965 mantiveram-se com aproximadamente os mesmos 16 ha. Isso ocorreu devido a uma diminuição das áreas de mata, que representava cerca de $55 \%$ do total (Tabela 16). Em 1978 a área total das matas se mantiveram em cerca de 29 ha, sendo 13 ha sobre os solos Li. Em 1995, as matas passaram a ocupar $134 \mathrm{ha}, 7 \%$ do total dos $\mathrm{Li}$ e $45 \%$ do total das matas, o que discorda dos dados obtidos por Borges et al. (1993), onde as áreas de mata decresceram de 1978 à 1991 (Tabela 16).

Com relação ao solo PV (com um total de 617,8 ha), em 1962 os mesmos eram ocupados com 13 ha de matas, $2 \%$ do total desse solo e $29 \%$ do total de matas. Em 1965 e 1978 não houve mudanças significativas das matas em relação ao PV, sendo 6 ha de mata sobre esse solo, o que pode ser devido a escala de trabalho em 1965, a qual apresentou menor detalhamento quando comparada com a de 1:35.000 em 1978, concordando com Demétrio (1977) e Borges et al. (1993) (Tabela 16).

O intervalo de declive entre $10-20 \%$, predominou nas áreas com matas em todos os anos (Figura 27), concordando com Flores (1995) que considera que em áreas de declives ondulados a forte ondulado é mais adequado áreas de preservação.

Em 1962, do total de 858 ha com intervalo de 10 a $20 \%$ de declive, as matas ocupavam 18,4 ha, ou seja $2 \%$ do total desse intervalo e $41 \%$ do total das áreas com mata (Tabela 17). As áreas de matas em 1965 e 1978 não apresentaram grandes diferenças (Figura 27), sendo que em média ocupavam 12 ha, ou 1,4\% do total do intervalo e $41 \%$ do total das áreas com mata. 
As áreas de matas tiveram um aumento de cerca de $33 \%$, de 1962 a 1995 concordando com Borges et al. (1993). Sendo assim, é interessante notar que as áreas de mata ocupavam, em 1995 intervalos de declividades de 0 a $2 \%$ e $>20 \%$. No intervalo de 0 a $2 \%$ de declividade observa-se um aumento de $23 \%$ das matas e nas declividades $>20 \%$ esse aumento foi de $42 \%$.

Em 1995 as matas passaram a ocupar 53,9 ha do intervalo de 10 a $20 \%$ de declividade, $6 \%$ do total do mesmo, o que corresponde a $40 \%$ do total das matas. (Tabela 17).

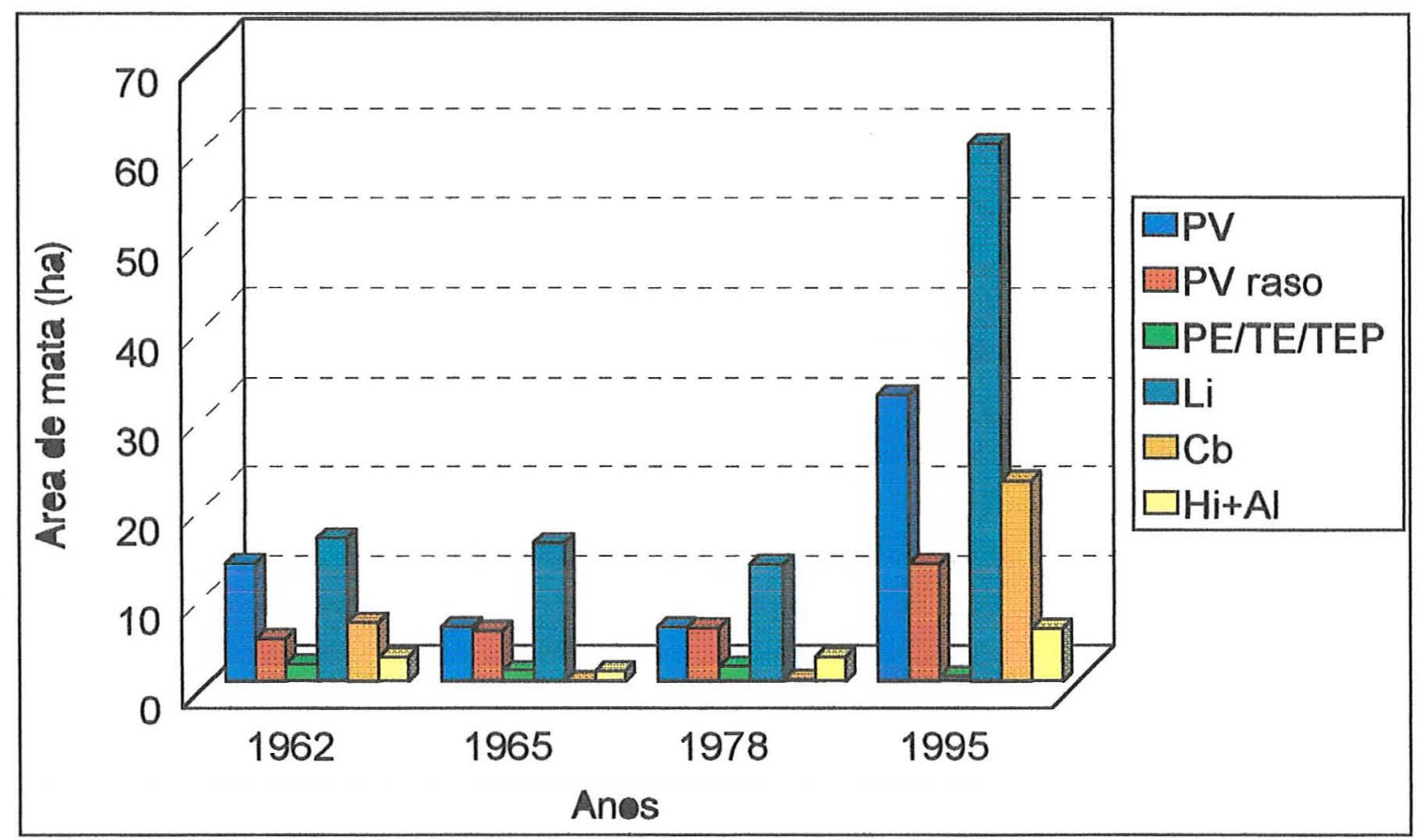

Figura 26 - Evolução das matas nos solos (ha).

Tabela 16 - Áreas em hectares das matas nos solos.

\begin{tabular}{|c|c|c|c|c|c|c|c|}
\hline \multirow[b]{2}{*}{ Ano } & \multicolumn{2}{|r|}{ Classes } & de & \multicolumn{3}{|l|}{ Solo } & \multirow[b]{2}{*}{$\begin{array}{c}\text { Área total } \\
\text { Plantada }\end{array}$} \\
\hline & PV & PV raso & $\mathrm{PE} / \mathrm{TE} / \mathrm{TEP}$ & $\mathrm{Li}$ & $\mathrm{Cb}$ & $\mathrm{Hi}+\mathrm{Al}$ & \\
\hline 1962 & 13,16 & 4,76 & 1,92 & 16 & 6,56 & 2,68 & 45,08 \\
\hline 1965 & 6,04 & 5,64 & 1,16 & 15,48 & 0 & 1,08 & 29,4 \\
\hline 1978 & 6,04 & 6 & 1,68 & 13,04 & 0,16 & 2,72 & 29,64 \\
\hline 1995 & 32,04 & 13,16 & 0,52 & 60,08 & 22,4 & 5,88 & 134,08 \\
\hline Área de solos & 617,8 & 223,5 & 64,4 & 908,1 & 97,2 & 40 & 1951 \\
\hline
\end{tabular}




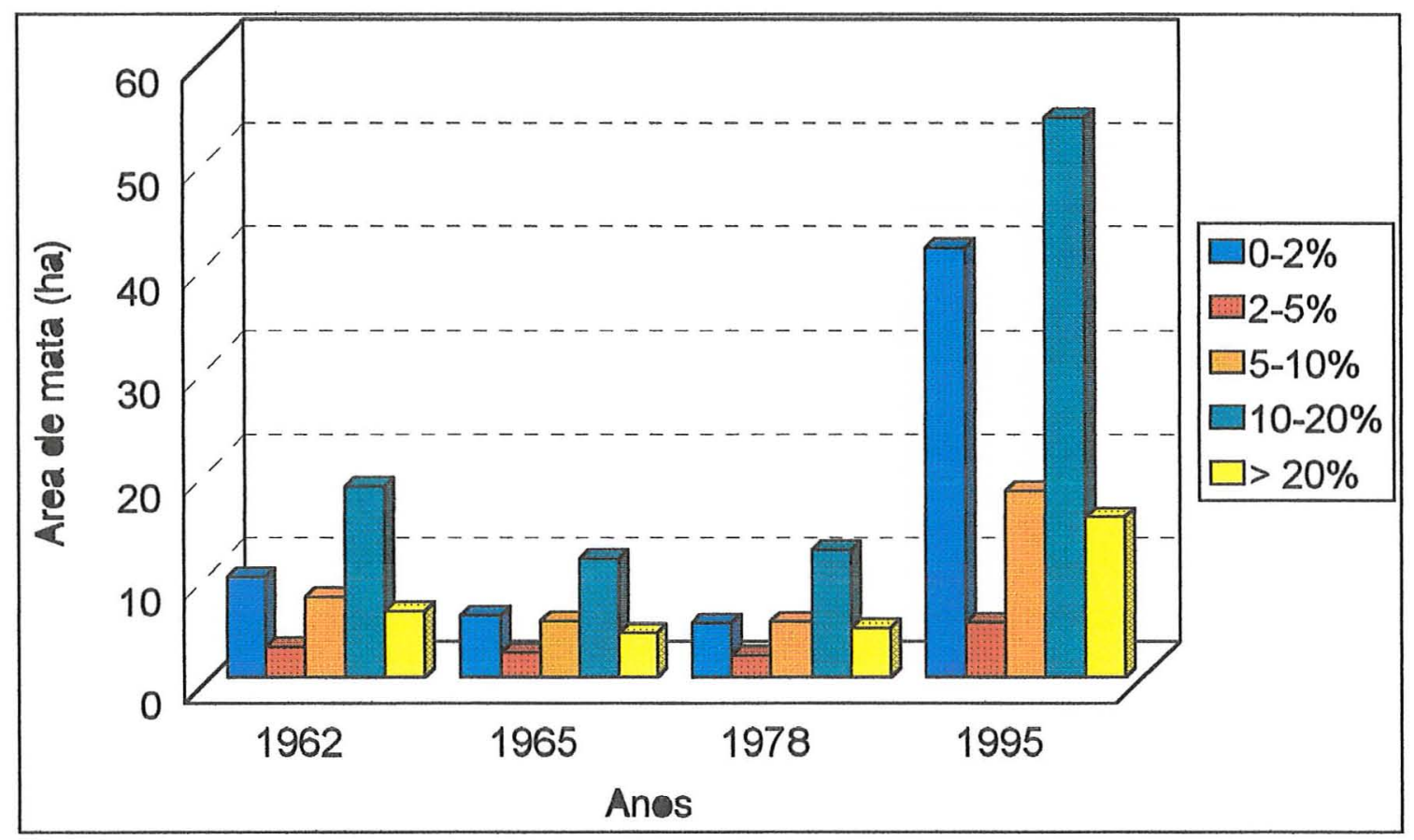

Figura 27 - Evolução das matas em suas respectivas classes de declive (ha).

Tabela 17 - Áreas em hectares de matas nas classes de declive.

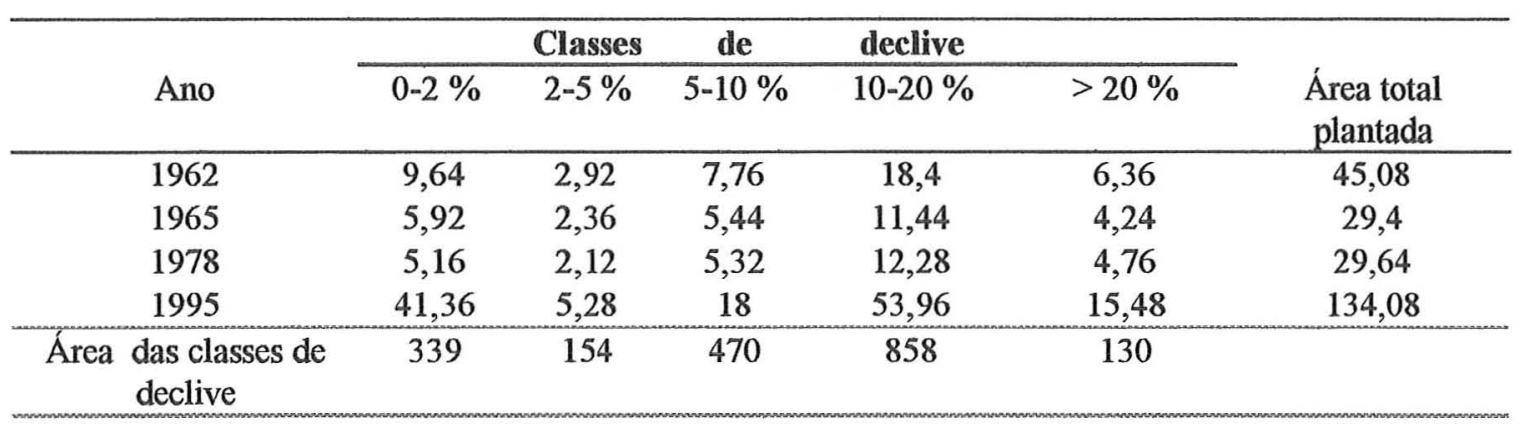




\subsubsection{Mata Ciliar}

A mata ciliar foi interpretada como aquela pouco densa e ao mesmo tempo ocorrente nos canais de drenagem. Nos casos em que essa vegetação era densa a mesma passou a ser interpretada como mata, mesmo quando ocorresse nos canais de drenagem.

O principal solo sob mata ciliar é o solo Litólico (Li) (Figura 28) onde segundo Flores (1995) solos Litólicos, em áreas de declive ondulado e forte ondulado, são adequados a tal tipo de uso. A mata ciliar em 1962, ocupava uma área de 126,9 ha, sendo que 77 ha, $60 \%$ do total sobre solo $\mathrm{Li}$ ( $8 \%$ desses solos), 30 ha, cerca de $24 \%$ do total da vegetação sobre solo $\mathrm{PV}$, (5 \% desses solos), sendo que os $16 \%$ restantes divididos entre os outros solos da área (Tabela 18).

Em 1965, 201,7 ha eram ocupados pela mata ciliar onde 124,7 ha, $62 \%$ da área com solo Li, 37 ha, $18 \%$ sobre solo PV. O total em 1978 era de 75 ha, onde $56 \%$ sobre Li e $27 \%$ sobre solo PV (Tabela 18 ).

Já em 1995, a mata ciliar ocupava uma área de 91 ha, onde 45,9 ha, $50 \%$ sobre Li e 30 ha, 33 \% sobre solo PV (Tabela 18). De 1962 a 1995, ocorreu uma diminuição da mata ciliar de $72 \%$. Por outro lado, muitas dessas áreas passaram a apresentar uma vegetação mais densa sendo designadas como mata. Tal fato, pode ser observado principalmente entre 1978 e 1995 nas Figuras 15 e 16, respectivamente.

Com relação as declividades, a mata ciliar, por se espalhar por toda a área, ocorre em todas as classes de declive. Predominam em ordem decrescente em áreas as classes de 10 a $20 \%, 0$ a $2 \%$ e de 5 a $10 \%$ (Figura 29 ).

De 0 a $2 \%$ de declividade, a mata ciliar em 1962 ocupava uma área de 24,8 ha, $19 \%$ do total, em 196546,6 ha cerca de $23 \%$, sendo $21 \%$ em 1978 e $27 \%$ do total em 1995 (Tabela 19). Assim sendo com exceção do ano de 1978, ocorreu um aumento da mata ciliar nessa classe de declive (Figura 29), discordando de Flores (1995) que considera solos Litólicos e Podzólicos em declive suave ondulado e plano a utilização de pastagens, culturas perenes e anuais. 
O intervalo de 5 a $10 \%$ de declividade não apresentou grandes variações em porcentagem de área total, ocupada pela mata ciliar, sendo que em 1962 ocupava 18 \% da área total, $16 \%$ em 1965 e 1978 e em 1995 17\% (Tabela 19). As classes de 10 a 20 \% abrangem uma área de 59,3 ha, cerca de $47 \%$ do total da vegetação em 1962 (126,9 ha). Em 1965, abrangia 92 ha, 46 \% da área total de 201,7 ha, 48 \% em 1978 e 44 \% em 1995, mantendo uma certa proporção para todos os anos em estudo (Tabela 19).

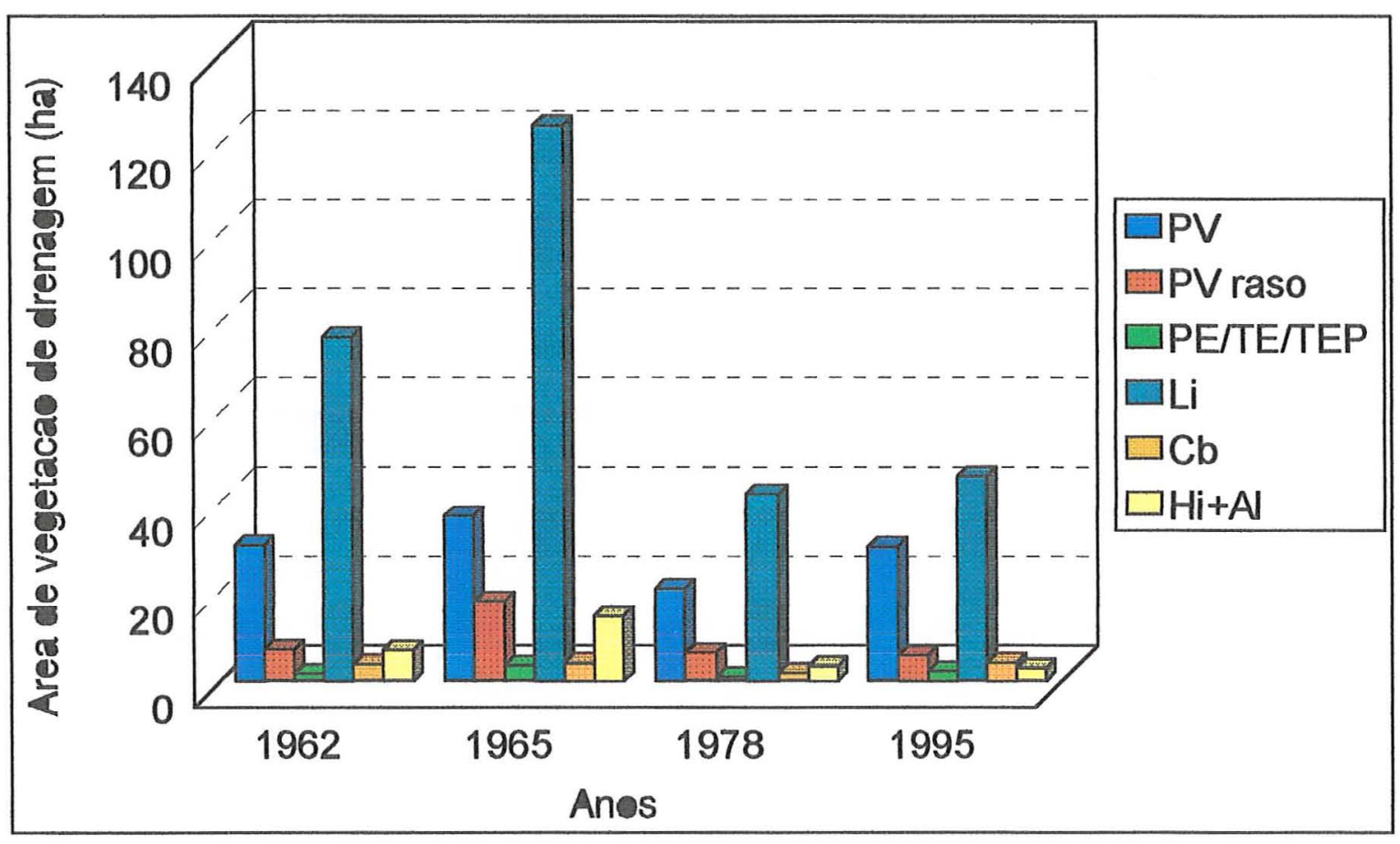

Figura 28 - Evolução da mata ciliar nos solos (ha).

Tabela 18 - Áreas em hectares de mata ciliar nos solos.

\begin{tabular}{|c|c|c|c|c|c|c|c|}
\hline \multirow[b]{2}{*}{ Ano } & \multicolumn{2}{|r|}{ Classes } & de & \multicolumn{3}{|l|}{ Solo } & \multirow[b]{2}{*}{$\begin{array}{l}\text { Área tota } \\
\text { Plantada }\end{array}$} \\
\hline & PV & PV raso & $\mathrm{PE} / \mathrm{TE} / \mathrm{TEP}$ & $\mathrm{Li}$ & $\mathrm{Cb}$ & $\mathrm{Hi}+\mathrm{Al}$ & \\
\hline 1962 & 30,48 & 7,08 & 1,68 & 77,04 & 3,72 & 6,92 & 126,92 \\
\hline 1965 & 37,12 & 17,88 & 3,44 & 124,76 & 4,04 & 14,52 & 201,76 \\
\hline 1978 & 20,68 & 6,32 & 0,96 & 41,96 & 1,8 & 3,32 & 75,04 \\
\hline 1995 & 30,2 & 5,76 & 2,24 & 45,96 & 4,16 & 2,96 & 91,28 \\
\hline Área dos solo & 617,8 & 223,5 & 64,4 & 908,1 & 97,2 & 40 & \\
\hline
\end{tabular}




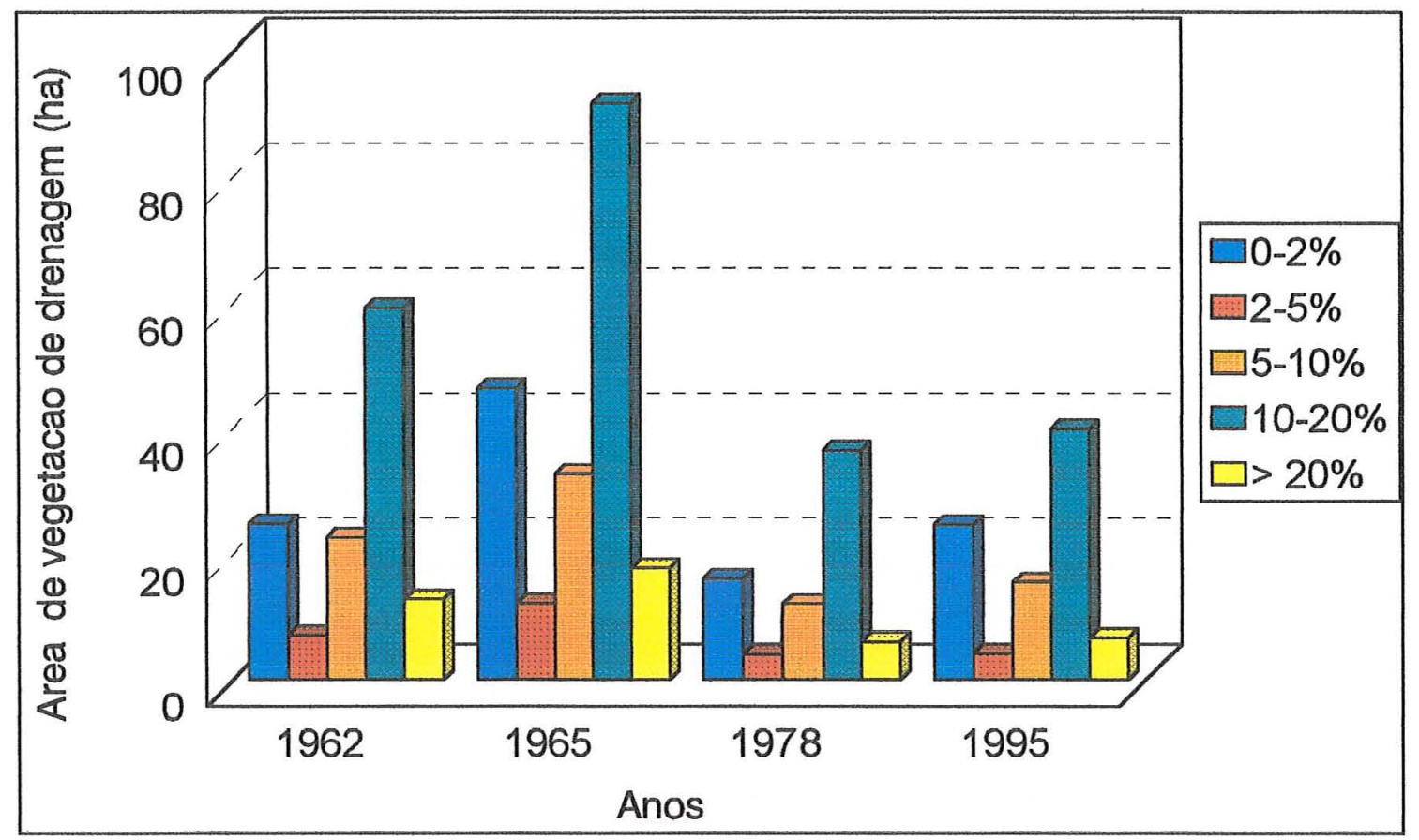

Figura 29 - Evolução da mata ciliar em suas respectivas classes de declive (ha).

Tabela 19 - Áreas em hectares de mata ciliar nas classes de declive.

\begin{tabular}{ccccccc}
\hline Ano & \multicolumn{3}{c}{ Classes } & de & declive & \\
\cline { 2 - 6 } & $0-2 \%$ & $2-5 \%$ & $5-10 \%$ & $10-20 \%$ & $>20 \%$ & $\begin{array}{c}\text { Área total } \\
\text { plantada }\end{array}$ \\
\hline 1962 & 24,84 & 7,12 & 22,68 & 59,36 & 12,92 & 126,92 \\
1965 & 46,6 & 12,28 & 32,84 & 92,12 & 17,92 & 201,76 \\
1978 & 16,16 & 4,04 & 12,16 & 36,56 & 6,12 & 75,04 \\
1995 & 24,68 & 4,24 & 15,56 & 40,04 & 6,76 & 91,28 \\
\hline $\begin{array}{c}\text { Área das classes } \\
\text { de declive }\end{array}$ & 339 & 154 & 470 & 858 & 130 & 1951 \\
\hline
\end{tabular}


4.3 Perdas de solo de acordo com tipo de cultura na Microbacia Hidrográfica do Ceveiro

Para o cálculo da perdas de solo, foi utilizada a EUPS. Apesar de não ser indicada para microbacias essa ainda é uma das únicas ferramentas para se estimar valores de perdas, concordando com Bertoni \& Lombardi Neto (1990). Com o intuito de se obter um valor de perdas de solo para cada tipo de uso da terra, utilizou-se o programa Idrisi, calculou-se a média ponderada de perdas de solo para cada ano em estudo (Figura 30). As maiores perdas de solo, foram ocasionas tanto pela evolução do meio fisico, como pelas ações antrópicas, sendo a segunda a de maior impacto, concordando com Bueno (1994).

A cultura anual foi a grande responsável pelas maiores perdas de solo na MHC. Em 1962 a área total cultivada era de 633,4 ha, os quais promoveram uma perda de 350,2 t/ha. Apesar do aumento de área cultivada em 1965 e da diminuição em 1978 (Tabela 7), os valores não apresentaram grandes alterações, 340,6 t/ha e 398,4 t/ha, respectivamente (Tabela 20). A menor perda de solo ocorreu em 1995, com 142,6 t/ha em uma área total cultivada de 2,9 ha onde 2,4 ha sobre Li e 0,5 ha com PV.

A cana-de-açúcar apresentou em média nos quatro anos uma perda de solo de 39 t/ha (Figura 30). A maior perda foi em 1962, com 44,4 t/ha em uma área total de 318,2 ha, onde 191 ha com solo PV e 66,5 ha sobre solo Li (Tabela 10). Em 1995, com uma área plantada de $1.319,6$ ha cerca de $66 \%$ da área total, a perda de solos foi de $38 \mathrm{t} / \mathrm{ha}$ (Tabela 20). Observa-se que neste ano a influência dos solos Li aumentou em relação a 1962 (Figura 20).

As maiores perdas de solo pela cultura anual, provavelmente está ligada a época de plantio. As culturas nessa área são plantadas em outubro/novembro, sendo que com isso, o solo permanece exposto durante a época das chuvas, de novembro a final de janeiro, considerando que as plantas estão em estágio inicial de desenvolvimento. A erosividade das chuvas tropicais, também colaboraram para a elevada perda de solo sob cultivo anual (El-Swaify et al., 1982). A cana-de-açúcar por sua vez, adota sistemas de 
manejo que preservam o solo na época de chuvas. Ou seja, em áreas de risco de erosão (o que ocorre na área pois a mesma apresenta solos Li e PV), em outubro ou novembro planta-se leguminosas, que protegem o solo durante o período das chuvas.

$\mathrm{O}$ pasto apresentou valores similares nos três primeiros anos de estudo, com 12 t/ha. O pasto sujo apresentou nos anos de 1962, 1965 e 1978 uma perda em média de 9,7 t/ha (Figura 30). Em 1995 ambos apresentaram uma perda de solo próxima a 5 t/ha (Tabela 20). Isso demonstra que as pastagens, devido a suas características, principalmente o sistema radicular graminóide. Também pelo fato de se encontrar permanente sobre o solo, diminui as perdas de terra.

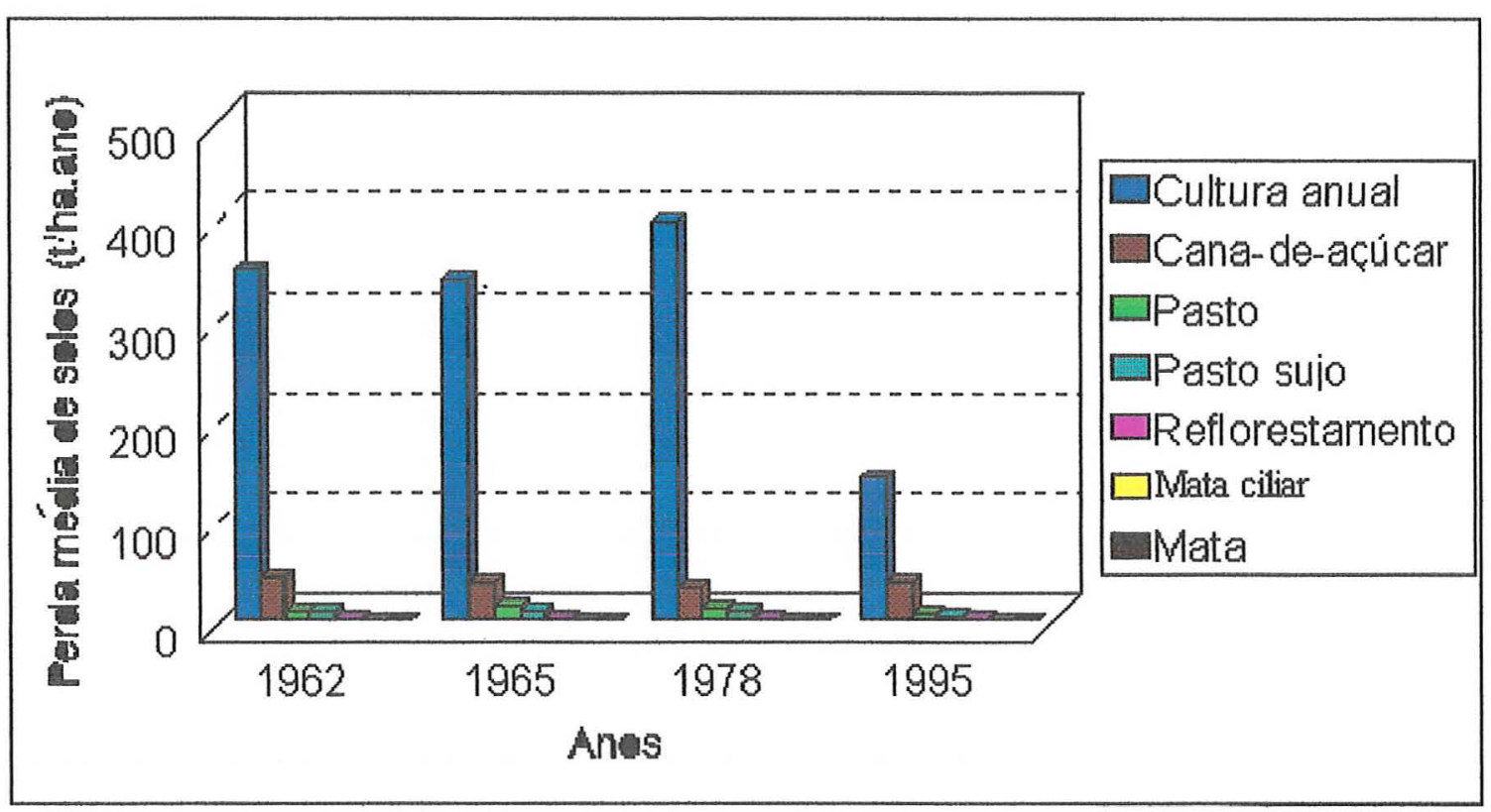

Figura 30 - Média ponderada das perdas de solo por cultura em cada ano de estudo.

Tabela 20 - Perdas médias de solo em toneladas/hectare por tipo de cultura.

\begin{tabular}{cccccccccc}
\hline Ano & Cultura anual & Cana-de-açúcar & Pasto & Pasto sujo & $\begin{array}{c}\text { Usos } \\
\text { Refloresta- } \\
\text { mento }\end{array}$ & Mata ciliar & Mata \\
\hline 1962 & 350,2 & 44,4 & 9,31 & 10,3 & 1,48 & 0,13 & 0,12 \\
1965 & 340,6 & 38,8 & 15 & 9,6 & 1,69 & 0,14 & 0,09 \\
1978 & 398,4 & 33,4 & 12 & 9,2 & 1,52 & 0,15 & 0,08 \\
1995 & 142,6 & 37,9 & 5,7 & 4,8 & 0,72 & 0,06 & 0,06 \\
\hline
\end{tabular}


A diferença das perdas de solo nos anos de 1962, 1965 e 1978 para o ano de 1995, pode ser devido a menor participação do PV nas áreas com pastos no último ano em estudo (Figura 22), estes solos são mais susceptíveis a erosão devido a diferença textural e estruturação dos mesmos, o que concorda com vários autores como Suares de Castro (1980), Resende \& Almeida (1985) e Ayres (1960).

Também não se observaram grandes diferenças de perdas de solo nos anos de 1962, 1965 e 1978 para reflorestamento, com perdas de 1,5 t/ha (Figura 30). Em geral nos três primeiros anos predominava o PV e o Li numa área plantada de aproximadamente 250 ha (Figura 24). Já em 1995 a área plantada era de 120 hă, principalmente nos $\mathrm{Li}$, onde a perda de solo foi de $0,7 \mathrm{t} / \mathrm{ha}$, o que se deve aos maiores teores de argila desses solos na MHC, promovendo uma melhor agregação da partículas, promovendo uma maior resistência a erosão, o que também foi verificado por Wishmeier et al. (1971), Resende \& Resende (1983) e Resende \& Almeida (1985).

A mata ciliar também manteve perdas de solo próximas nos anos de 1962, 1965 e 1978 0,14 t/ha. Em 1995 a perda de solo foi de 0,06 t/ha (Tabela 20), onde a influência do Li foi maior neste último ano em estudo (Tabela 18).

As perdas de solo em matas foram diminuindo gradativamente ao longo dos anos (Figura 30). Em 1962 0,12 t/ha; 1965 0,09 t/ha; 1978 0,08 t/ha e em 1995 0,06 t/ha. As áreas de mata nos solos Li foram aumentando gradativamente de 1962 à 1995 (Figura 26 e Tabela 16). Provavelmente, o crescimento da vegetação entre 1962 e 1995, promoveu um adensamento da mata, com conseqüente preservação do solo.

Em todos os anos em estudo as áreas com pastagens, reflorestamento, mata e mata ciliar, apresentaram as menores perdas de solo. As maiores perdas são de áreas com pastagens e as menores são de áreas com mata (Figura 30).

$A$ influência da erodibilidade dos solos $(\mathrm{K})$ (Tabela 4), numa mesma cultura, parece ser predominante para no cálculo das perdas de solo. Assim, em solos com maior teor de argila temos uma diminuição dos valores da erodibilidade do solo $(\mathrm{K})$, como conseqüência ocorre uma diminuição nas perdas de solo. É o caso dos solos $\mathrm{Li}$ que apresentaram sob a mesma cultura, valores de perdas de solo menores que o PV. 
A maioria dos solos PV na área de estudo apresenta-se com uma textura arenosa/média e média/argilosa (Tabela $2 \mathrm{~b}$ ), e os solos Li apresentam texturas médias e argilosas predominando a segunda. Dessa forma, os índices de erodibilidades calculados a partir do modelo proposto por Denardin (1990) são menores para os solos Li (Tabela 4). Tais fatos concordam com os resultados de Wischmeier et al. (1971), Resende \& Resende (1983) e Resende \& Almeida (1985).

As diferenças de perdas de solo entre as culturas sobre o mesmo solo (Tabela 20), pode ser explicada pelo fator uso e manejo c e $P$, (Tabela 5). $O$ fator $P$ foi considerado constante para toda a área em estudo, atribuindo-se o valor 0,5 , o qual significa práticas de plantio em contorno, concordando com Ranieri (1996). Para o fator (c) os valores foram diferenciados (Tabela 5). À cultura anual foi atribuído um valor de $\mathrm{Cb}=0,55$ e a cana-de-açúcar um valor de $\mathrm{Cb}=0,11$, explicando assim a grande diferença de perdas de solo, concordando com os dados de Stein et al. (1987).

\subsection{Tolerância de perdas de solo}

Considera-se tolerável, a perda de solo que mantenha bons níveis de produtividade, por um longo período de tempo. Vários estudos foram realizados para se determinar uma perda de solo aceitável, gerando controvérsias quanto aos valores exatos para cada classe de solo, não existindo até hoje limites de tolerância de perdas em solos tropicais, concordando com Pierce et al. (1984), Sparovek \& jong van Lier (1993).

Para se estabelecer valores de tolerância de perdas de solo na MHC, utilizou-se valores sugeridos por Lombardi Neto \& Bertoni (1975). Assim, para classes de solos com B textural, considerou-se uma tolerância de perda de solo de 12 t/ha.ano e para os demais solos da área de estudo ( $\mathrm{Li}, \mathrm{Hi}+\mathrm{Al}, \mathrm{Cb}) 4$ tha.ano. Os níveis de tolerância 1 vez, 5 vezes, 10 vezes e $>10$ vezes representam respectivamente, tantas vezes as perdas de solo acima do tolerável.

Portanto, foram obtidos mapas de tolerância para os anos em estudo, o que só foi possível devido a módulos específicos de análises e exibição dos resultados no SIG, de 
acordo com Alves (1990), Vettorazzi (1992) e Câmara (1993). Da mesma forma, a manipulação dos SIG, possibilitou o zoneamento de áreas de forma mais eficiente, substituindo métodos mais onerosos e de dificil manipulação, concordando com Sano et al. (1990). Tais resultados podem ser observados nas Figuras 31, 32, 33 e 34.

Ocorre uma visível diminuição das áreas com > 10 vezes a tolerância de 1962 para 1995. Por outro lado, ocorre um aumento nas áreas das classes de 10 vezes e 5 vezes a tolerância, principalmente na classe de 10 vezes a tolerância (Figura 35), tal fato se deve a uma diminuição das culturas anuais, com maiores perdas de solo na área de estudo e um aumento da cultura canavieira com perdas menores (Tabela 20), concordando com Stein et al. (1987).

As perdas de solo, em níveis toleráveis estão associadas às áreas com reflorestamento, mata ciliar, mata e pastagens, com perdas que variam de 15 t/ha.ano à 0,06 t/ha.ano (Tabela 20). Portanto, com o desmatamento e aumento das áreas de canade-açúcar entre 1962 e 1995 ocorreu uma diminuição nas áreas com níveis toleráveis, principalmente entre 1978 à 1995, período de aumento nas áreas cultivadas com cana-deaçúcar (Figura 35). Tais mudanças nos níveis de tolerância estão intimamente ligados principalmente ao tipo de uso da terra, o que acarreta uma mudança no fator $\mathrm{c}$, concordando com Stein (1987). 


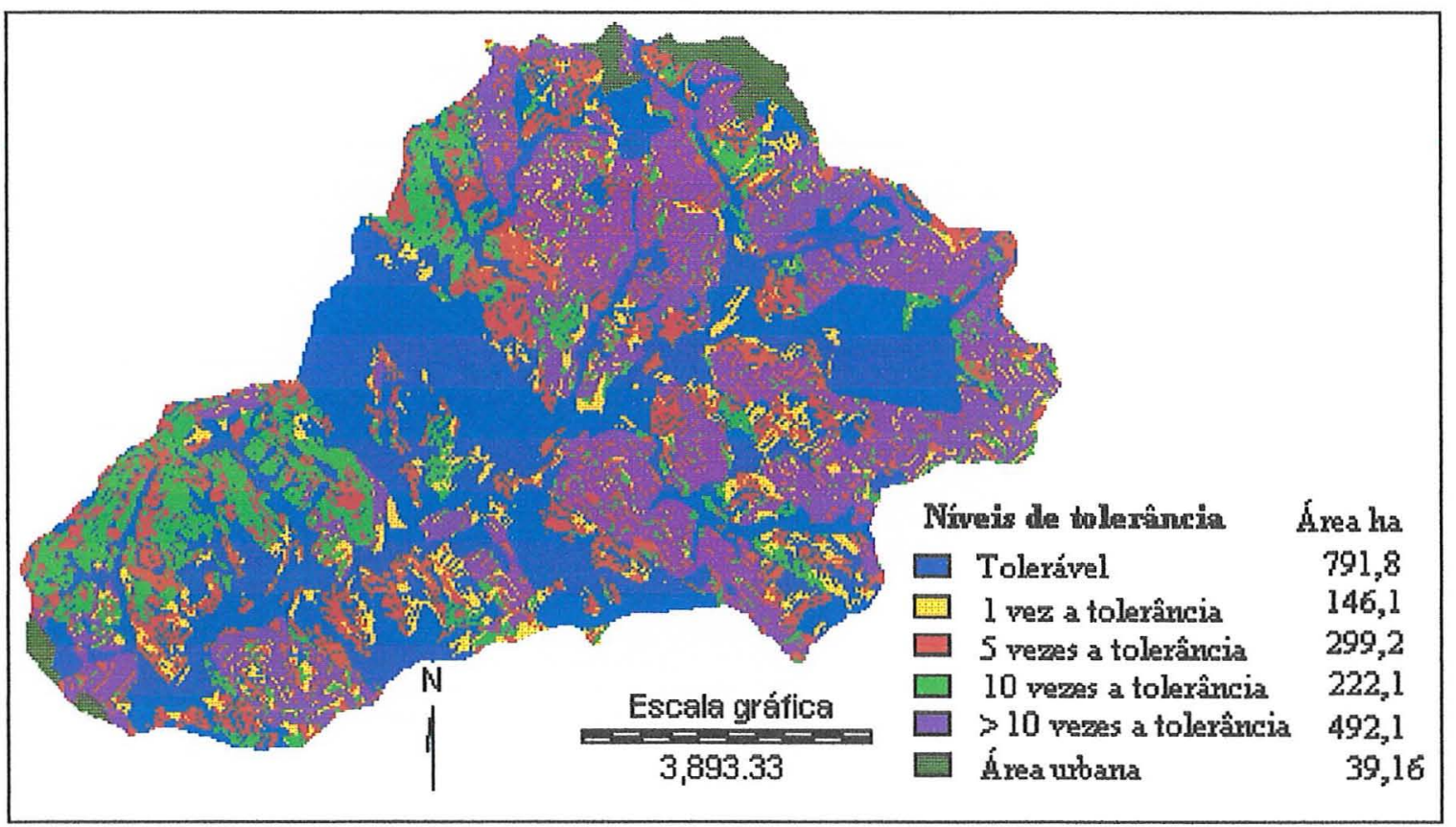

Figura 31 - Mapa de tolerância as perdas de solo em 1962.

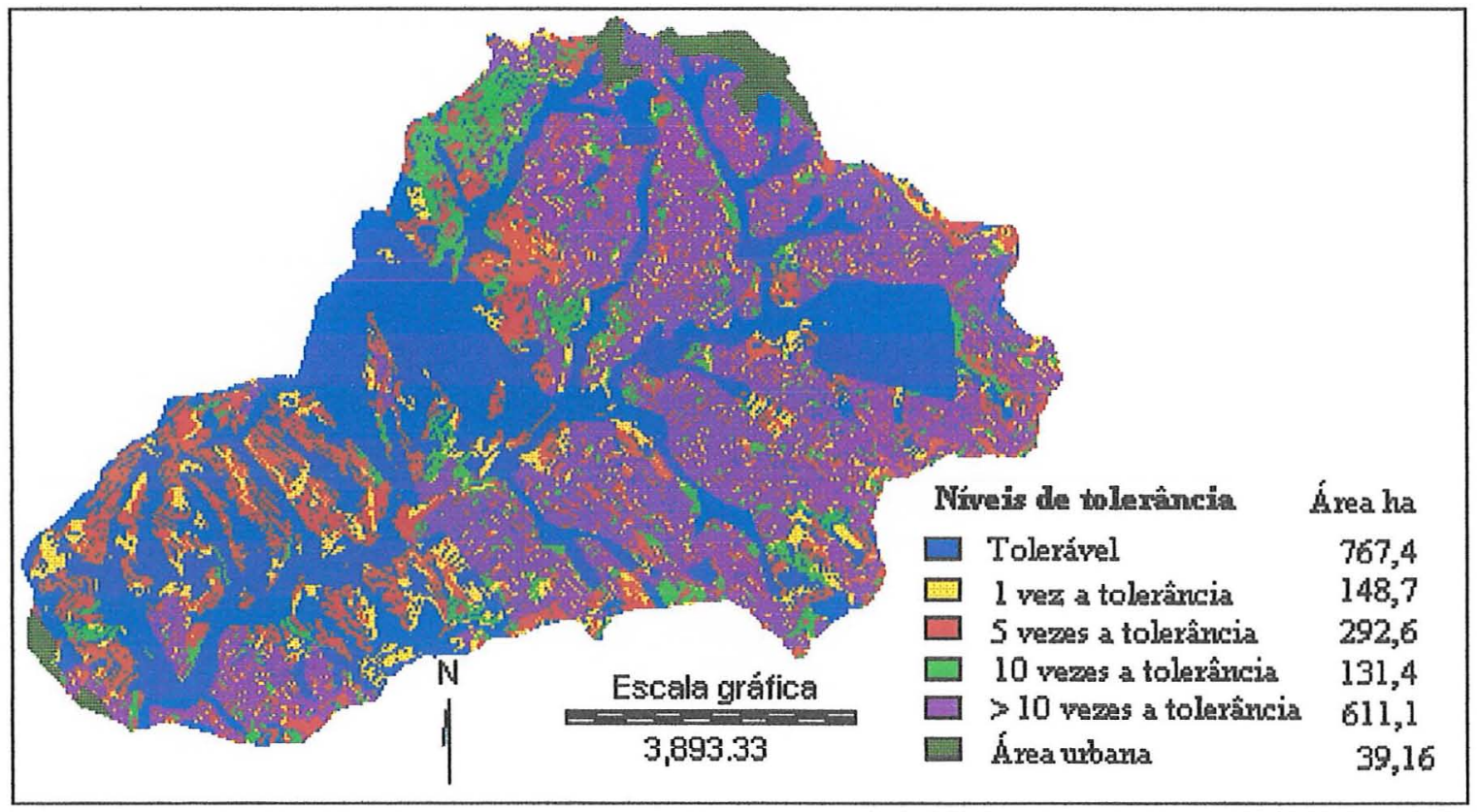

Figura 32 - Mapa de tolerância as perdas de solo em 1965. 


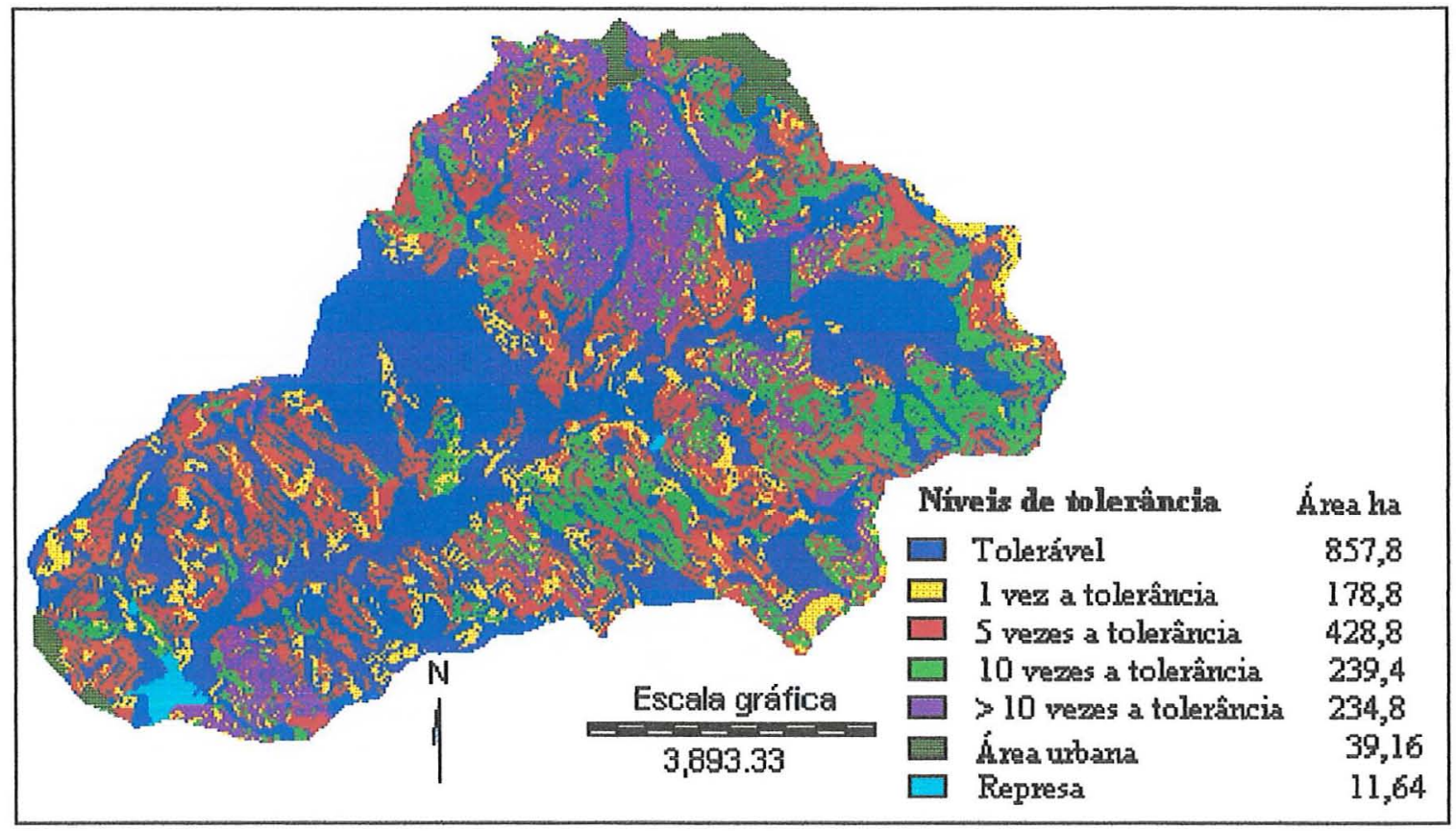

Figura 33 - Mapa de tolerância de perdas de solo em 1978.

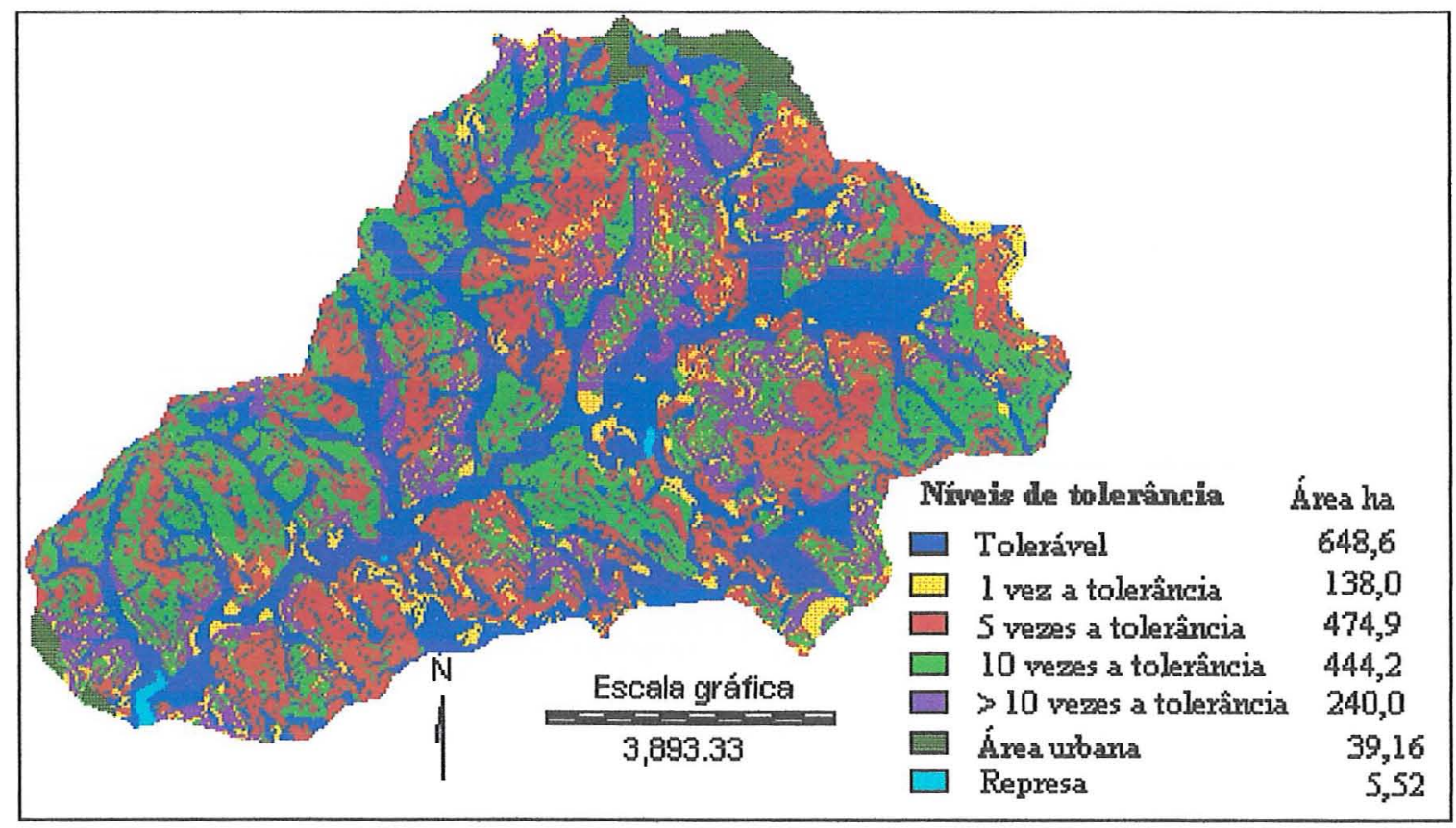

Figura 34 - Mapa de tolerância as perdas de solo em 1995. 


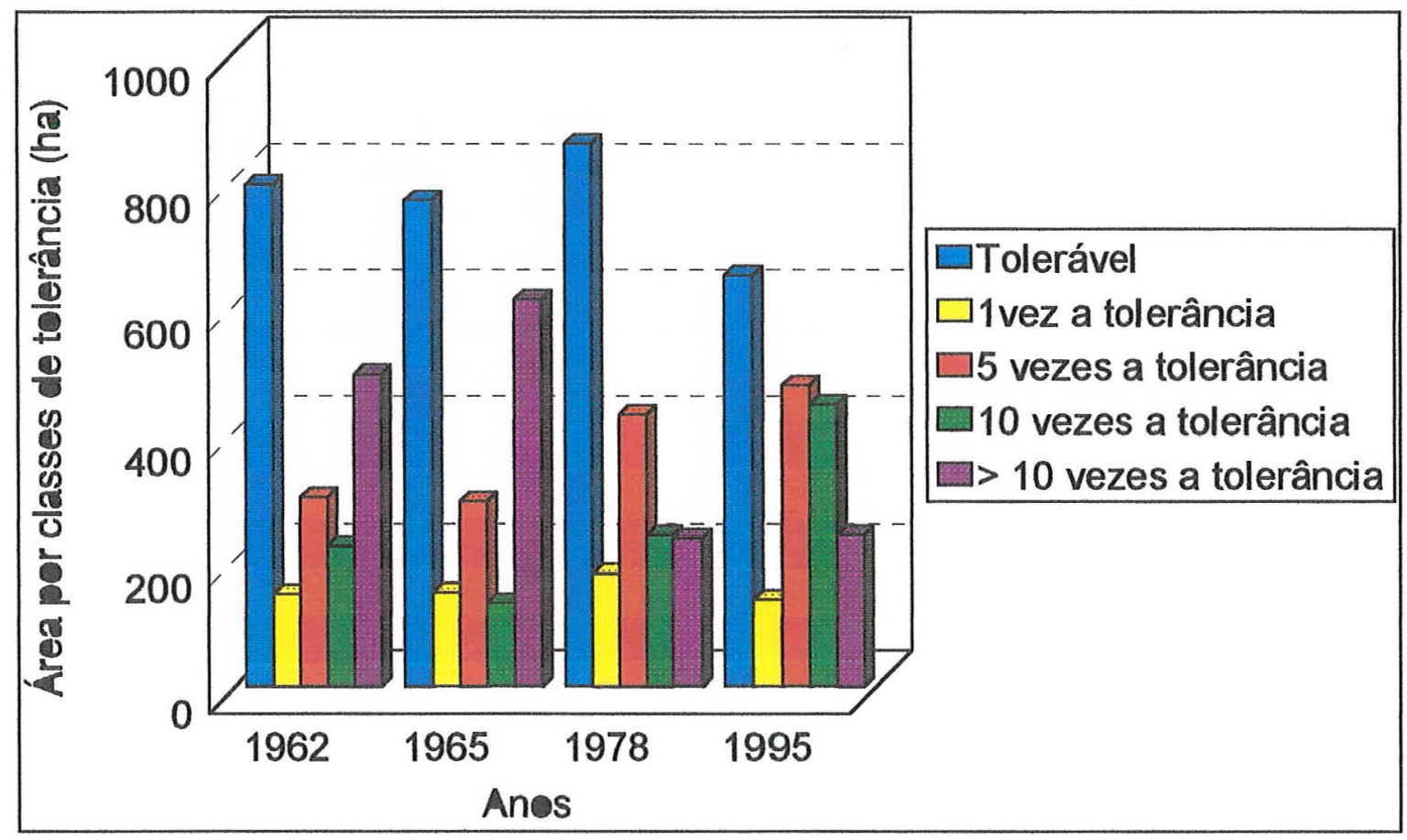

Figura 35 - Dimensão das áreas de tolerância de perdas de solo (ha).

Em 1962 , 791,8 ha (cerca de 40,6 \% do total da área) apresentavam a perda de solo tolerável (Tabela 21). Nesse caso as áreas de reflorestamento, mata ciliar, mata e pastagens representavam $1.033 \mathrm{ha}, 52 \%$ do total (Tabela 7).

No ano de $1965,767,4$ ha (39\% da área total), estava com nível tolerável de perdas (Tabela 21). Neste ano, as áreas com as mesmas culturas anteriormente citadas, apresentaram uma diminuição de $4 \%$ de 1962 à 1965, sendo responsáveis por 994 ha, cerca de $50 \%$ da área de estudo (Tabela 7). Em 1978, 857,8 ha (44\% da área da MHC) encontrava-se com perdas toleráveis (Tabela 21), onde as culturas citadas representavam 1.216 ha, $61 \%$ da área (Tabela 7).

Em 1995, as perdas de solo toleráveis ocupavam uma área de 648 ha, cerca de 33 $\%$ do total da área (Tabela 21), sendo que o reflorestamento, a mata ciliar, a mata e as pastagens representavam apenas 623 ha, $31 \%$ do total (Tabela 7). 
Tabela 21 - Dimensão das área em hectares de níveis de tolerância de perdas de solo.

\begin{tabular}{cccccc}
\hline & \multicolumn{2}{c}{ Níveis } & de & \multicolumn{2}{c}{ Tolerância } \\
\cline { 2 - 6 } Anos & Tolerável & 1 vez a tolerância & 5 vezes a tolerância & 10 vezes a tolerância $>10$ vezes a tolerância \\
\hline 1962 & 791,8 & 146,1 & 299,2 & 222,1 & 492,1 \\
1965 & 767,4 & 148,7 & 292,6 & 131,4 & 611,1 \\
1978 & 857,8 & 178,8 & 428,8 & 239,4 & 234,8 \\
1995 & 648,6 & 138,0 & 474,9 & 444,2 & 240,0 \\
\hline
\end{tabular}

Assim sendo, com a substituição, principalmente das culturas anuais pela cana-deaçúcar entre 1962 e 1995, provocou uma diminuição das áreas com tolerância de perdas acima de 10 vezes, notando-se um aumento principalmente em 1978 nas áreas com 5 vezes a tolerância e em 1995 nas áreas com 10 vezes a tolerância, o que se deve principalmente as mudança do uso da terra e conseqüentemente uma diminuição do valor do fator C, concordando com Stein (1987). A cultura da cana-de-açúcar iniciou sua ocupação por solos Li com menor erodibilidade em 1978, e se alastrou por toda a área em 1995, em solos de maior erodibilidade PV (Figura 20).

\subsection{Aptidão agrícola ou potencialidade agrícola das terras}

A aptidão agrícola das terras da MHC, foi avaliada e mapeada com o auxilio de sensoriamento remoto (fotografias aéreas) e do software SAMPA, versão 2.0 desenvolvido por Koffler (1992). Portanto a interação do sensoriamento remoto e do geoprocessamento é importante para a avaliação do uso da terra, concordando com Alves (1993). O SAMPA é um sistema de análise espacial de componentes ambientais. O programa após, análises preliminares das limitações dos solos e declividades da área, organiza áreas de aptidão para quatro grandes grupos de culturas e promove uma melhor adequação do uso da terra, concordando com Formaggio et al. (1992), os quais consideram como ideal para se promover a adequação do uso da terra, um sistema semi automático e não subjetivo.

O sistema SAMPA (Koffler, 1992), que se baseou nos moldes de classificação da classe de capacidade de uso (Lepsch et al., 1991), é um dos mais utilizados no Brasil 
(Assad, 1993) e possibilitou gerar mapas de adequação dos usos da terra, que são a seguir descritos.

\subsubsection{Aptidão agrícola para culturas de ciclo curto}

As culturas de ciclo curto se caracterizam por apresentarem períodos entre semeadura e colheita inferiores a seis meses. Geralmente no Estado de São Paulo, essas culturas estão associadas a semeadura em período chuvoso e colheita da epóca das chuvas, dependendo do ciclo vegetativo. As áreas da microbacia, aptas para culturas de ciclo curto podem ser observadas na Figura 36.

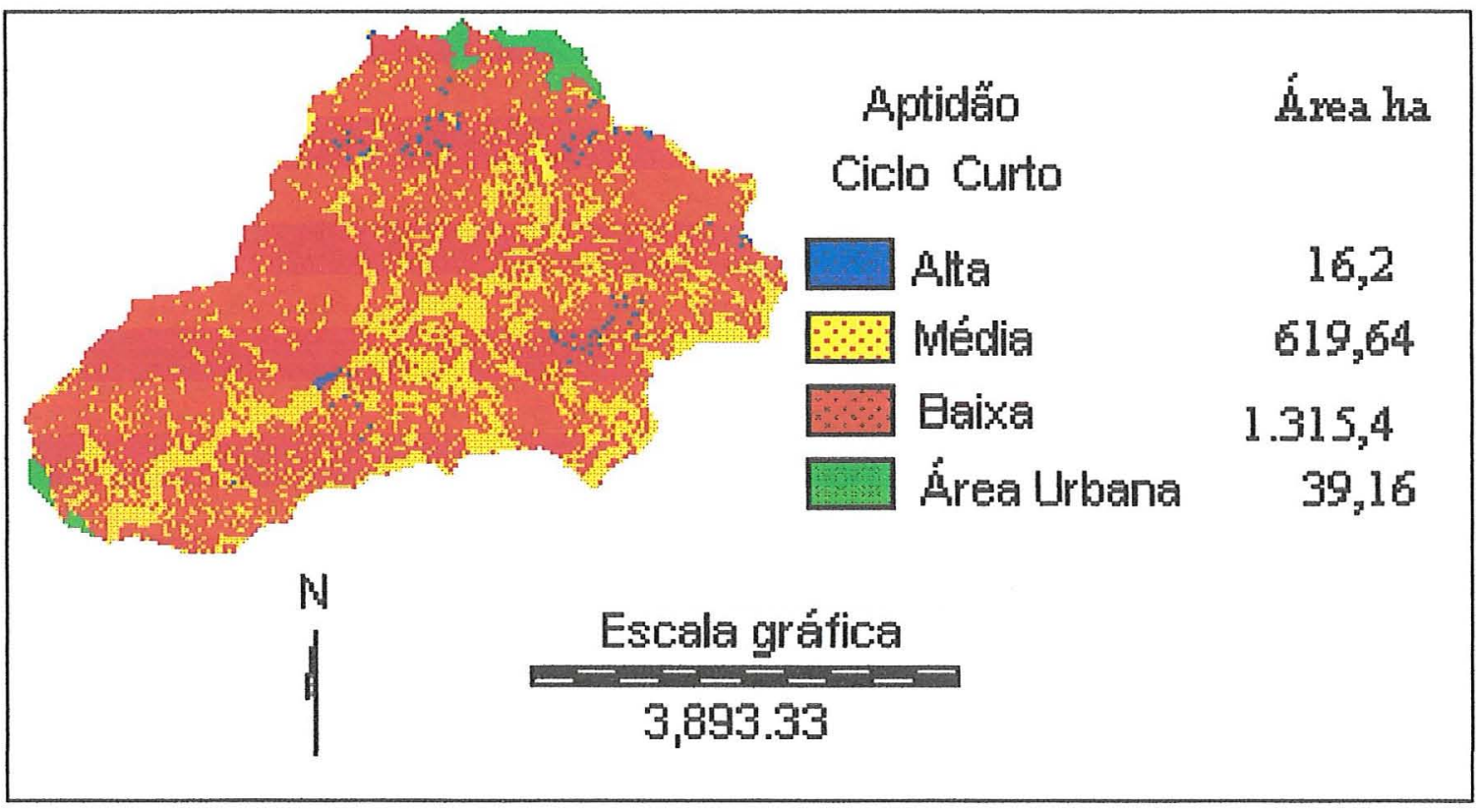

Figura 36 - Aptidão para culturas de ciclo curto.

A microbacia se caracteriza por não apresentar uma grande área com aptidão para ciclo curto, sendo que apenas 16,2 ha $(0,8 \%$ do total da microbacia) é de alta aptidão. As áreas de média aptidão representam 619,64 ha (31\% do total), onde ambas perfazem 
um total de 635,84 ha (cerca de $32 \%$ da área). A aptidão baixa para ciclo curto representa $1.315,4$ ha, $66 \%$ da área e a área urbana $2 \%$ do total.

\subsubsection{Aptidão agrícola para culturas de ciclo longo}

As culturas de ciclo longo se caracterizam por apresentar ciclo vegetativo maior que um ano, subdivididas em semi-perenes como a mandioca e a cana-de-açúcar, e perenes como o café e a fruticultura em geral. Essas culturas sofrem o efeito do clima durante todo o ano, e apresentam sistema radicular mais profundo que as culturas anuais. As áreas aptas para culturas de ciclo longo, estão representadas na Figura 37.

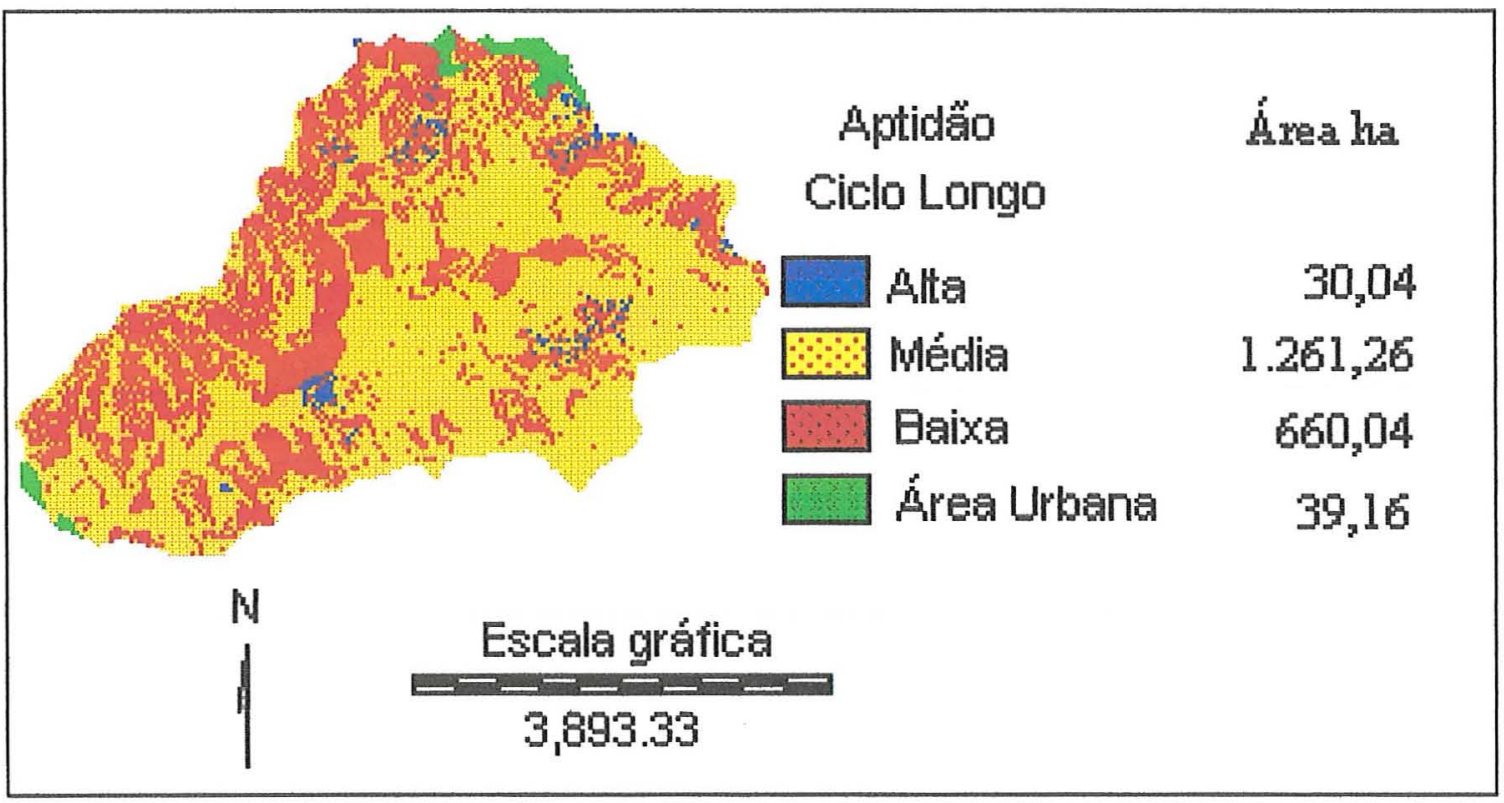

Figura 37 - Aptidão para culturas de ciclo longo.

Para o ciclo longo, a MHC apresenta apenas 30 ha com alta aptidão, o que representa $1,5 \%$ do total e para a aptidão média, $1.261,26$ ha (63\% da área), ou seja cerca de 1291,3 ha, (64,8 \% do total da área), que pode ser cultivado com culturas de ciclo longo. A aptidão baixa para ciclo longo ocupa 660,04 ha (33\% do total). 


\subsubsection{Aptidão agrícola para pastagens}

As áreas de pastagens vêm se caracterizando pela baixa rentabilidade econômica da produção animal em regime de pasto (Koffler, 1996), e apresentam-se aptas para as mais diversas condições edáficas, o que é possível devido ao desenvolvimento de diferentes espécies de forrageiras. Dessa forma, as pastagens vêm gradativamente cedendo espaço para outros usos mais lucrativos.

As forrageiras, geralmente perenes, durante seu ciclo vegetativo, sofrem os efeitos climáticos adversos durante todo o ano, além, dos cortes intermitentes por pastoreio. Mesmo assim, o sistema radicular das forrageiras se desenvolve bem e cobrem todo o terreno durante o ano, e com menor intensidade nos períodos de seca, os quais reduzem os processos erosivos. A Figura 38, representa a aptidão da MHC para áreas de pastagem.

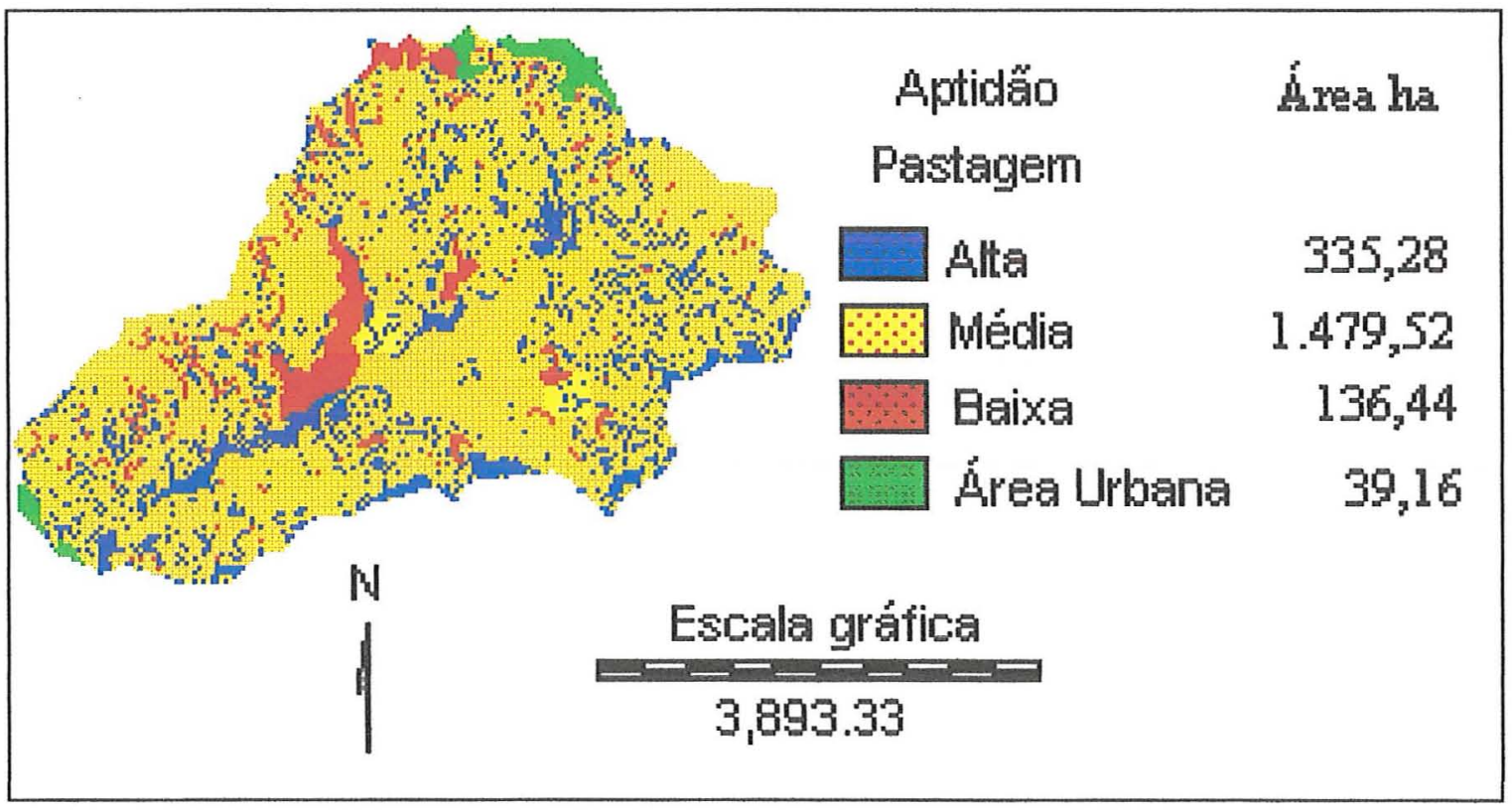

Figura 38 - Aptidão agrícola para áreas de pastagens.

As pastagens em relação as demais culturas apresentam as maiores áreas com alta aptidão ou seja , 335,28 ha (17\% do total). Para aptidão média a área é de 1.479,52 ha, 
$74 \%$ da MHC, o que juntamente com aptidão alta, perfazem um total de $1.814,8$ ha ou $91 \%$ da área total. As áreas restritas para pastagem tem um total de 136,44 ha $(7 \%$ do total da MHC).

\subsubsection{Aptidão agrícola para silvicultura}

Nesta denominação, são enquadradas áreas de formações florestais implantadas pelo homem. As espécies mais utilizadas no Estado de São Paulo pertencem aos gêneros Pinus e Eucalypitus. Várias são as variedades disponíveis, sendo que estas se adaptam as mais diferentes condições edafo-climáticas. A Figura 39, representa a aptidão da MHC para a silvicultura.

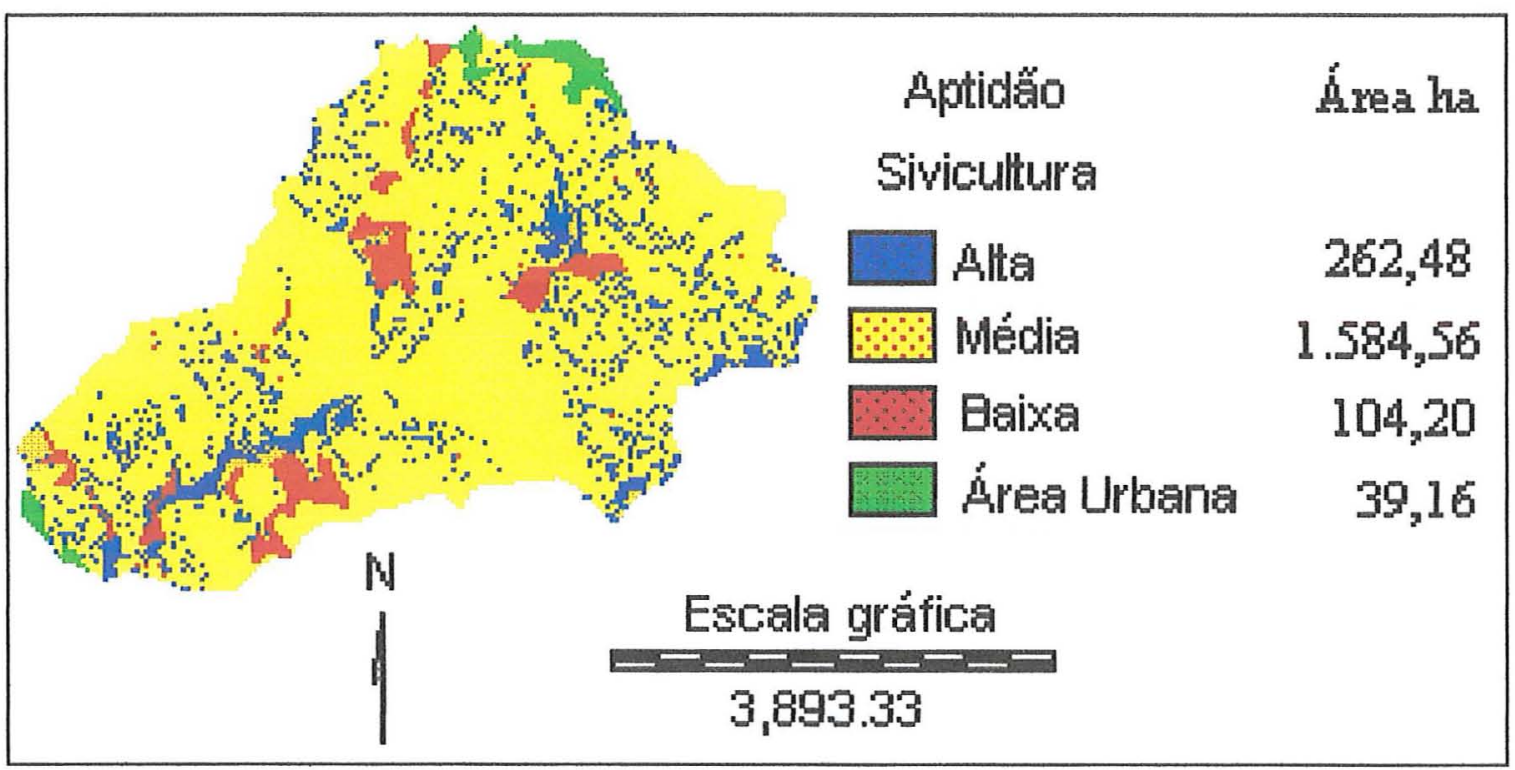

Figura 39 - Aptidão agrícola para silvicultura.

A microbacia apresenta 262,48 ha, com aptidão alta para a silvicultura (13\% da área total). As áreas com aptidão média ocupam $1.584,56$ ha $(79,6 \%$ do total da 
microbacia), perfazendo juntamente com a aptidão alta $1.847,04$ ha (93 \% do total da área). As áreas com aptidão baixa ocupam 104,2 ha, apenas 5 \% da área.

Dessa forma, considerando as áreas com aptidão alta e média na microbacia apresenta a silvicultura com $93 \%$, pastagens com $91 \%$ e culturas de ciclo longo com $64,5 \%$ todas aptas e grande parte inapta a culturas de ciclo curto.

\subsubsection{Uso preferencial das terras}

Com o intuito de se obter um uso da terra que leve em consideração as qualidades e limitações das terras, para se manter a produtividade por um longo prazo, o programa SAMPA gerou um mapa de uso preferencial (Figura 40), concordando com Lepsch et al. (1991), que consideram que uso adequado da terra o primeiro passo para uma agricultura correta.

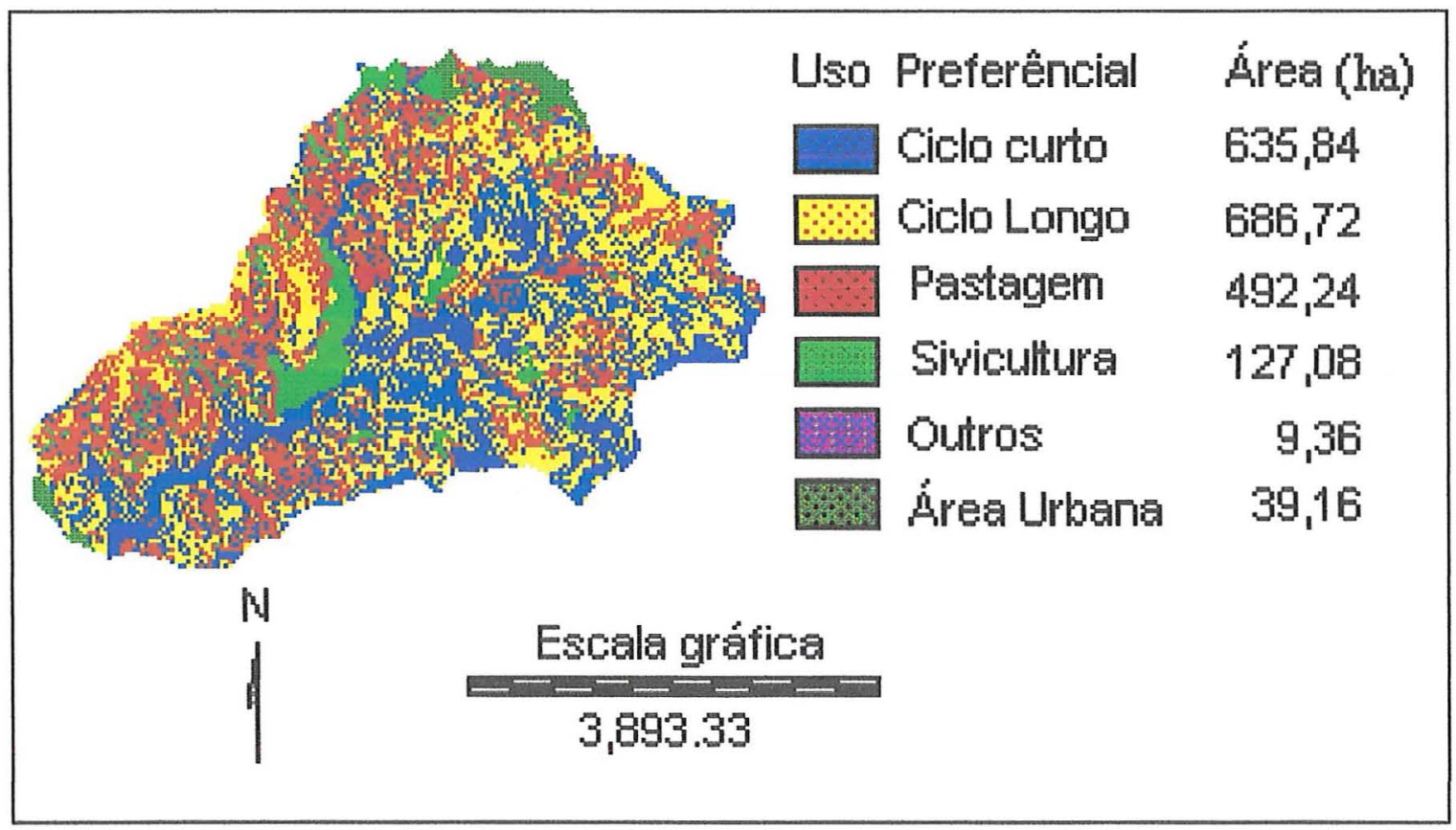

Figura 40 - Uso preferencial das terras. 
O mapa de uso preferencial, indica qual a melhor distribuição e ocupação mais adequado na MHC. Assim, a área poderia ser explorada com 635,84 ha cerca de $32 \%$ com culturas de ciclo curto, 686,72 ha, que correspondia $34 \%$ com culturas de ciclo longo, 492,24 ha correspondendo a $25 \%$ com áreas de pastagens e 127,08 ha com áreas para silvicultura, $6 \%$ do total da microbacia. $\mathrm{O}$ uso referente a "outros" considera as áreas da represa, a qual não é analisada pelo programa, o que está de acordo com Koffler (1996).

As culturas de ciclo curto, ocorrem nas menores declividades da área, principalmente sobre os solos $\mathrm{Li}$, perfazendo $45 \%$ do total da área e algumas áreas sobre Terra Roxa Estruturada, Terra Roxa Estruturada Podzólica e Podzólico Vermelho Escuro, 3,2\% do total da microbacia. As áreas com ciclo longo estão espalhadas por toda a área com uma maior concentração ao Norte da MHC, ocorrendo principalmente sobre o solo PV e o solo $\mathrm{Li}$.

As pastagens também se distribuem por toda a microbacia, concentrando-se principalmente ao sul da área sobre o solo PV. Finalmente, a silvicultura, aparece em locais bem determinados na microbacia, sobre os Cambissolos.

\subsubsection{Uso preferencial x Uso da terra em 1995 (Atual) - Impacto ambiental}

Na comparação do uso preferencial, sugerido pelo software SAMPA com o uso das terras em 1995 (considerado como uso atual), da Figura 16, obteve-se um mapa de intensidade de uso das terras (Figura $41 \mathrm{e}$ Tabela 22). Com o mapa de intensidade de uso da terra, foi possível avaliar as ações antrópicas bem como seu impacto ambiental, concordando com Jenkis et al. (1994). Bertolini (1993) considerou a microbacia hidrográfica como a unidade que melhor reflete as ações antrópicas e seu impacto no ambiente. Tal afirmação encontra respaldo na resolução $n^{\circ}$ 001/86 do CONAMA (1981), onde a bacia hidrográfica é considerada como área a ser analisada para o estudo de impactos ambientais (Mariano) citado por Ranieri (1996). O mapa de intensidade de uso 
mostra a distribuição das áreas adequadamente utilizadas, sub-utilizadas e utilizadas acima do potencial natural.

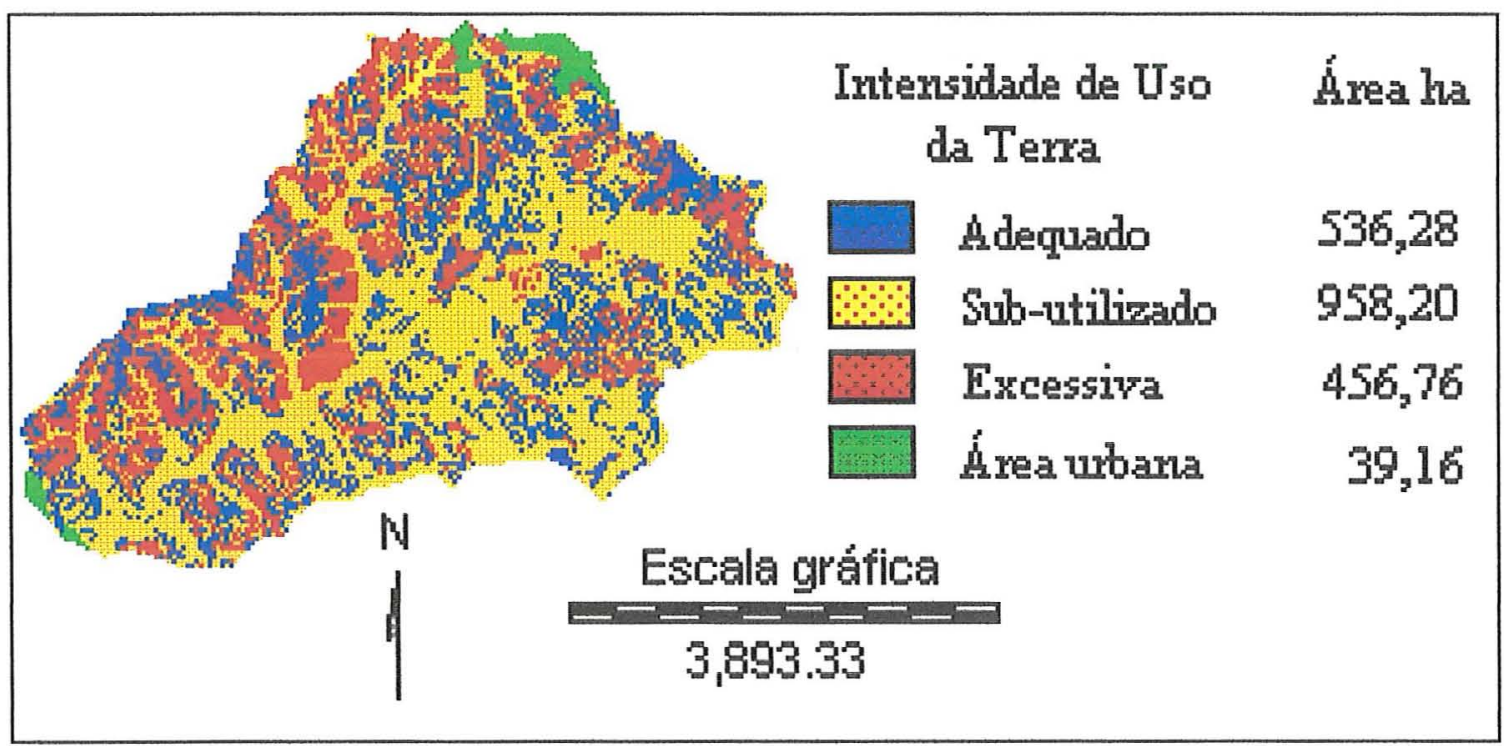

Figura 41 - Intensidade de uso das terras.

Do total da área apenas 536,28 ha, $27 \%$ está sendo utilizada adequadamente e 456,76 ha (cerca de $23 \%$ ) está sendo utilizada acima do potencial. As áreas subutilizadas, representam 958,2 ha, ou seja $48 \%$ do total da microbacia.

As áreas adequadas, bem como as áreas excessivas representadas no mapa de intensidade de uso, são devidas principalmente às áreas de cana-de-açúcar na microbacia.

Em 1995, a cana-de-açúcar perfazia um total de 1.319,64 ha, (cerca de $66 \%$ do total). As áreas sub-utilizadas, ocorrem principalmente nas menores declividades da área e reflorestamento, onde as mesmas áreas seriam mais indicadas para ciclo curto e longo e pastagens. As áreas respectivas de uso da terra e uso preferencial podem ser observadas na Tabela 22 . 
Tabela 22 Áreas em hectares de uso preferencial e uso da terra em 1995.

\begin{tabular}{cccc}
\hline Uso da Terra & Uso da terra 1995 & Uso Preferencial (SAMPA) & Diferença \\
\hline Ciclo curto & 2,96 & 635,84 & 632,88 \\
Ciclo longo & $1.319,64$ & 686,72 & 632,92 \\
Pastagens & 277,64 & 492,24 & 214,60 \\
Silvicultura & 120,12 & 127,08 & 7,08 \\
Outros & 225,36 & 9,36 & 216 \\
Área Urbana & 39,16 & 39,16 & 0 \\
\hline Total & 1990,4 & 1990,4 & $1.703,48$ \\
\hline
\end{tabular}

Pode-se notar, que há diferenças entre o uso preferencial e o de 1995. As áreas com ciclo curto e longo representam as maiores diferenças entre o uso proposto e o atual, onde 632 ha, são utilizados pela cultura de cana-de-açúcar, considerado como subutilizado, concordando com Koffler (1996). As pastagens apresentam-se em menor área no uso atual do que o proposto, diferindo em 214 ha. As áreas de silvicultura não apresentam grandes diferenças em área, porém, o reflorestamento no uso atual ocupa áreas diferentes das propostas do uso preferencial. O uso da terra, "outros", neste caso, refere-se as áreas de mata e mata ciliar apresentando uma diferença entre o atual e o proposto. 


\section{CONCLUSÕES}

A análise e interpretação dos resultados obtidos, com o material existente e os métodos empregados, permitiram as seguintes conclusões e observações:

1. A utilização de fotografias aéreas permitiu avaliar a evolução do uso da terra na área durante um período de 33 anos.

2. As escalas 1:35.000 e 1:25.000 foram as que mais facilitaram a interpretação dos dados. A escala de 1:60.000 promoveu perda de detalhes devido a pequena escala.

3. Entre 1965 e 1995, a cultura anual diminuiu sua área ocupada que era de $42 \%$ para $0,15 \%$, em favor do aumento da área de cana-de-açúcar, que passou de 16 para $66 \%$. A pastagem e o reflorestamento também contribuíram para a expansão da cana-de-açúcar, com diminuição em área de $48 \%$ e $42 \%$ respectivamente.

4. O maior crescimento da cana-de-açúcar ocorreu de 1978 à 1995 devido aos incentivos governamentais do Proalcool.

5. As áreas de mata nativa e de área urbana apresentaram uma aumento entre 1962 e 1995.

6. As principais classes de solos ocupados pelas culturas foram os solos Litólicos e solos Podzólicos os quais em 1962 eram ocupados pelas culturas anuais. Em 1995, a cultura canaviera ocupou mais os solos Litólicos os quais são mais próximos da usina. A maior expansão nesses solos ocorreu após 1978.

7. Quando levado em consideração uma mesma cuitura, o valor de erodibilidade do solo $(\mathrm{K})$ foi o fator mais representativo para o cálculo das perdas de solo, pois os mesmos apresentam valores menores para solos mais argilosos (solos Litólicos), que 
apresentaram menores perdas. As diferenças de perdas de solo entre as culturas podem ser explicadas pelo fator uso-manejo o qual é maior para cultura anual e menor para cana-de-açúcar.

8. A maior parte da microbacia apresenta-se com áreas acima dos níveis de tolerância de perdas de solo. Observou-se uma diminuição das áreas acima de 10 vezes a tolerância e um aumento nas áreas com 5 e 10 vezes a tolerância o que se deve principalmente a expansão da cultura canavieira.

9. Em $1995,48 \%$ da área estava sendo utilizada abaixo do seu potencial, $27 \%$ sendo utilizada adequadamente e $23 \%$ com intensidade excessiva. As principais distorções no uso da terra, nas áreas adequadas e excessivas, representadas no mapa de intensidade de uso, foram devidas a cana-de-açúcar. Nas áreas sub-utilizadas , onde em 1995 ocorriam reflorestamentos, mata ciliar e mata, são em sua maioria indicados para ciclo curto e pastagens.

10. O impacto ambiental causado pela expansão desordenada da cana-de-açúcar, tem como indicador a represa da Vila de Artemis, a qual tinha por finalidade o fornecimento de água potável para a vila. Implantada em 1978 em uma área de 12 ha de espelho d'água, em 1995 passou a 0,6 ha devido ao assoreamento. 


\section{REFERÊNCIAS BIBLIOGRÁFICAS}

ALENCAR, A.A.C.; VIEIRA, I.C.G.; NEPSTAD, D.C. Análise multitemporal do uso do solo e mudanças da cobertura vegetal em antiga área agrícola da Amazônia Oriental. (campact disc). In: SIMPÓSIO BRASILEIRO DE SENSORIAMENTO REMOTO, 8., Salvador, 1996. Resumos. São José dos Campos : INPE, 1996.

ALVES, L.M. Sistemas de Informação Geográfica In: SIMPÓSIO BRASILEIRO DE GEOPROCESSAMENTO, 1., São Paulo, 1990. Anais. São Paulo: USP, Escola Politécnica, 1990. p.66- 78.

AMANCIO, A. V. Fotointerpretação e avaliação conservacionista do uso da terra em três decênios da Fazenda Milho Branco "Ataliba Leonel" - Manduri, SP. Piracicaba, 1986. 64 p. Dissertação (Mestrado) Escola Superior de Agricultura "Luiz de Queiroz", Universidade de São Paulo.

AMARAL, G. Introdução ao sensoriamento remoto e suas aplicações. Campinas: UNICAMP, IG, 1992. 124p.

ANDERSON, P. S. Fundamentos para fotointerpretação. Rio de Janeiro: Sociedade Brasileira da Cartografia, 1982. 136p. 
ASSAD, M.L.L. Uso de uma sistema de informações geográficas na determinação da aptidão agrícola de terras. Revista Brasileira de Ciência do Solo, v. 19, n.1, p. 133$139,1995$.

ASSAD, M.L.L. Sistema de informações geográficas na avaliação da aptidão de terras. In: ASSAD, E.D.; SANO, E.E. Sistema de informações geográficas aplicações na agricultura. Brasília: EMBRAPA, 1993. 179p.

ASSUNÇÃO, G. V.; FORMAGGIO, A. R.; ALVES, A. R. Mapa de aptidão agrícola das terras e uso adequado das terras: uma abordagem usando o SGI e imagens de satélite. In: SIMPÓSIO BRASILEIRO DE SENSORIAMENTO REMOTO, 6., Manaus, 1990. Anais. São José dos Campos: INPE, 1990. p.162 - 166.

AYRES, A.C. La erosion del suelo y su control. Barcelona: Omega, 1960. 441p.

BATISTA, E.A., Levantamentos fitossociológicos aplicados à vegetação de cerrado, utilizando-se de fotografias verticais. Piracicaba, 1982. 122p. Disseração (Mestrado) Escola Superior de Agricultura 'Luiz de Queiroz", Universidade de São Paulo.

BERTOLINI, F. Perspectivas de falta de madeira em futuro próximo. In: CONGRESSO FLORESTAL PANAMERICANO, 1., Curitiba, 1993. Anais. Curitiba: UFPR, 1993. v. 3 , p. 40 .

BERTONI, J.; LOMBARDI NETO, F. Conservação do solo. Piracicaba: Livroceres, 1990.392p.

BERTONI, J.; LOMBARDI NETO, F.; BENATTI, JR. Equação de perdas de solo. Boletim Técnico Instituto Agronômico, n.21, p.25, 1975. 
BORGES, M.H.; PFEIFER, R.M.; DEMATTÊ, J.A.M. Evolução e mapeamento do uso da terra, através de imagens aerofotogramétricas e orbitais em Santa Bárbara D'oeste (SP). Scientia Agricola, v.50,n. 3,p. 365-371, out./dez. 1993.

BUENO, C.R.P. Zoneamento da Suscetibilidade à Erosão dos Solos da Alta e Média Bacia do Rio Jacaré-Pepira-SP, com vistas ao Planejamento Ambiental. Rio Claro, 1994. 132p. Tese (Doutorado). Instituto de Geociências e Ciências Exatas, Universidade Estadual Paulista "Julio de Mesquita Filho".

BURROUGH, P.A. Principles of geographical information systema for land resources assessment. Oxford: Claredon Press, 1986. 193p.

CÂMARA, G. Anatomia de Sistemas de Informações Geográficas: visão atual e perspectivas de evolução. In: ASSAD, E.D.; SANO, E.E. (Coord.). Sistema de Informações Geográficas: Aplicações na Agricultura. Planaltina: EMBRAPA, CPAC. 1993.

COELHO, A.G.S. Variação decenal do uso agrícola das terras. Campinas: Instituto Agronômico, 1974. 32p. (IAC Boletim Técnico, 11).

CREPANI, E. Princípios básicos de sensoriamento remoto. São José dos Campos:: CNPQ, INPE. 1993. 45p.

CRÓSTA, A. P. Processamento digital de imagens de sensoriamento remoto. Campinas: UNICAMP, 1992. $170 \mathrm{p}$.

DAVIDSON, D. A. Application of Geographical Information Systems to land evolution: Course on land evolution. Valencia: Palau de Pineda, 1992. 29 p. 
DENARDIN, J.E. Erodibilidade do solo estimado por meio de parâmetros físicos e químicos. Piracicaba. 1990. 70 p. Tese (Doutorado) Escola Superior de Agricultura "Luiz de Queroz", Universidade de São Paulo.

DEMÉTRIO, V. A. Variação de características de redes de drenagem em função da escala das fotografias aéreas verticais. Piracicaba. 1977. 107p. Dissertação (Mestrado) Escola Superior de Agricultura "Luiz de Queroz", Universidade de São Paulo.

DONZELI, P.L.; VALÉRIO FILHO, M.; PINTO, S. A. Técnicas de sensoriamento remoto aplicadas ao diagnóstico básico para planejamento e monitoramento de microbacias hidrográficas. Documentos IAC, n.29, p. 91-119, set. 1992.

EASTMAN, J.R. Idrisi: user guide. Worcester: Clark University, 1992.

EL-SWAIFY, S.A.; DANGLER, E.W.; ARMSTRONG, C.L. Soil erosion by water in the tropics research extension series. Hawaii: College of Agriculture and Juman Resources, 1982.

FLORES, M. X. Uso agrícola do solo: Principais tipos de solo, potencial de utilização e impactos ambientais In: TAUK-TORNISIELO, S. M.; GOBBI, N.; FORESTI, C. et al. Análise ambiental estratégias e ações. T.A. Queiroz, 1995. Cap. 7, p. 280290.

FORMAGGIO, A.R.; ALVES, D.S.; EPIPHANIO, J.C.N. Sistemas de informação geográficas na obtenção de mapa de aptidão agrícola e taxa de adequação de uso das terras. Revista Brasileira de Ciência do Solo, v.16, n.2, p. 249-256, maio/ago. 1992. 
HUDSON, N.W. Soil conservation. Ithaca: Cornell University Press, 1971. 324p.

INSTITUTO DE PESQUISAS TECNOLÓGICAS DO ESTADO DE SÃO PAULO. Mapa geológico do Estado de São Paulo. São Paulo: IPT, DMGA, 1981a. v.1. 126p. Escala 1:500.00. (IPT, Monografia, 6).

INSTITUTO NASCIONAL DE PESQUISAS ESPACIAIS/ENGESPAÇO INDUSTRIA DE COMÉRCIO LTDA. Sistemas de Informação Geográfica: manual do usuário versão 2.0. São José dos Campos, 1988. 162p.

JENKINS, A.; PETERS, N.E; RODHE, A. Hidrology. In: MOLDAN, B.; CERNY, J. (Coord). Biogeochemistry of small catchments: a tool for evironmental research. Chichester: Jonh Wiley, 1994, p. 31-54.

KOFFLER, N.F. Identificação da cultura da cana-de-açúcar (Saccharrum spp.) através de fotografias aéreas infravermelhas coloridas e dados multiespectrais do satélite landsat, Piracicaba, 1982. 234p Tese (Doutorado) Escola Superior de Agricultura "Luiz de Queiroz", Universidade de São Paulo.

KOFFLER, N.F.; CAVALLI A C.; CHIARINI J.V.; NOGUEIRA F.P. Inventário canavieiro com auxílio de fotografias aéreas. Piracicaba: PLANALSUCAR, 1979. $38 \mathrm{p}$.

KOFFLER, N.F.; CHIARINI J.V.; CAVALLI A C.; NOGUEIRA F.P. Inventário canavieiro com auxílio de fotografias aéreas. Piracicaba: PLANALSUCAR, 1980. $22 \mathrm{p}$. 
KOFFLER, N.F. Sistema de análise ambiental para planejamento agrícola: versão 1.0. Rio Claro: CEAPLA, 1992. 41p.

KOFFLER, N.F. Uso das terras da Bacia do Rio Bauru (SP): Situação atual e potencialidade agrícola. Mimesis, v.17, n.1, p. 99-125, 1996.

LEPSCH, I.F. BELLINAZZI, J.R.; BERTOLINI, D.; ESPÍNDOLA, C.R. Manual para levantamento utilitário do meio físico e classificação de terras no sistema de capacidade de uso. Campinas: Sociedade Brasileira de Ciência do Solo, 1991. 175p.

LOBÃO, S.M.F. Entradas de fotografias aéreas coloridas de médio formato em SIG (compact disc). In: SIMPÓSIO BRASILEIRO DE SENSORIAMENTO REMOTO, 8., Salvador, 1996. São José dos Campos: INPE, 1996.

LOMBARDI NETO, F.; BERTONI, J. Tolerância de perdas de terra para solos do Estado de São Paulo. Campinas: IAC, 1975. p. 12 (IAC Boletim Técnico,28).

MARCHETTI, D.A.B; GARCIA, G.J. Princípios de fotogrametria e fotointerpretação. São Paulo: Nobel, 1978. 257p .

MARIANO, M.T. Uma analise da participação da sociedade civil na gestão dos recursos hídricos do Estado de São Paulo. São Carlos, 1996. Dissertação (Mestrado) Escola de Engenharia de São Carlos, Universidade de São Paulo.

MARQUES, J.Q.A.; J. BERTONI; G.B. BARRETO. Perdas por Erosão no Estado de São Paulo. Campinas, Instituto Agronômico. Bragantia, 1961. 20:1143-1181. 
MERE, L.D.G.; BRAGA, R.E.G. Uso da terra ao redor da UHE de Tucuruí - PARÁ uma analise histórica. In: SIMPÓSIO BRASILEIRO DE SENSORIAMENTO REMOTO, 5., Natal, 1988. Anais. São José dos Campos: INPE, 1988. v.1, p.64-77.

MOLDAN, B.; CERNY, J. Small catchment research. In: MOLDAN, B.; CERNY, J. (Coord). Biogeochemistry of small catchments: a tool for evironmental research. Chichester: John Wiley, 1994. p. 1-29.

MYERS, V.I. Crops and soils. In: American Society of Photogrametry. Manual of Remote Sensing. Falls Church, Virginia, V. 2, p. 1715-1805, 1975.

OLIVEIRA; J.B.; BERG, M. Aptidão agrícola das terras do Estado de São Paulo: Quadricula de Araras II. Memorial descritivo. Boletim técnico Instituto Agronômico, n. 102, p. $60,1985$.

PAIVA, RM.; SCHATTAN, S.; FREITAS, C.F.T. Setor agrícola do Brasil. Rio de Janeiro: Ed. Forese Universitária, 1976. 480p.

PIERCE, F.J.; LARSON, W.E.; DOWDY, R.H. Soil loss tolerance: Maintenance of long-term of productitity. Journal of Soil and Water Conservation. v. 39, n. 2, p. 10-14, Jan./feb. 1984.

PINTO, S.A.F.; VÁLERIO FILHO, M.; GARCIA, G.J. Utilização de imagens TM/Landsat na análise comparativa entre dados de uso da terra e de aptidão agrícola. Revista Brasileira de Ciência do Solo, v. 13, n.1, p. 101-110, jan/abr. 1989.

POLITANO, W. Estudo fotointerpretativo sobre a morfometria das áreas de dois solos Podzólicos Vermelho - Amarelo, Piracicaba, 1980, 169p. Tese (Doutorado) Escola Superior de Agricultura 'Luiz de Queiroz”, Universidade de São Paulo. 
POLITANO, W.; CORSINI, P.C.; LOPES, L.R.; et al. Caracterização por fotointerpretação da ocupação do solo no municipio de Monte Alto, SP. Engenharia Agrícola, v.7, n.1, p.17-25, 1983.

POLITANO, W.; SACCHI, E.; LOPES, L.R.; et al. Levantamento por fotointerpretação da cobertura vegetal do início da década de setenta do município de Jacutinga, SP. Científica, v.18, n.1, p. 29-41, 1990.

RABBEN, E.L. Fundamentals of photointerpretation In: AMERICAN SOCIETY OF PHOTOGRAMETRY. Manual of photographic interpretation. Washington, 1960. Cap. 3, p.99-186.

RAMALHO, A.; PEREIRA, E.G.; BEEK, K.J. Sistemas de avaliação da aptidão agrícola das terras. Brasília: EMBRAPA, 1978. 70 p.

RANIERI, S.B.L. Avaliação de métodos e escalas de trabalho para determinação de risco de erosão em bacia hidrográfica utilizando Sistema de Informações Geográficas (SIG). São Carlos, 1996. 128p. Dissertação (Mestrado) - Escola de Engenharia de São Carlos - Universidade de São Paulo.

RAY, R.G. Fotografias aéreas na interpretação e mapeamento geológico. São Paulo: Instituto Geográfico e Geológico, 163p. 1963.

RESENDE, M. Características do solo e da paisagem que influenciam a susceptibilidade à erosão. In: SIMPÓSIO SOBRE MANEJO E CONSERVAÇÃO DO SOLO NO CERRADO, Campinas, 1992. Anais. Campinas: Fundação Cargill, 1992. p.32-67. 
RESENDE, M.; ALMEIDA, J.R. de. Modelos de predição de perdas de solo: uma ferramenta para manejo e conservação do solo. Informe Agropecuário, v.11, n.128, p.38-54, 1985.

RESENDE, M.; FRANZMEIER, D. P. Mineralogy of brazilian oxisols aproposed general model. Viçosa: UFV, 1982. $2 p$.

RESENDE, M.; RESENDE, S. Levantamento de solos: uma estratificação de ambientes. Informe Agropecuário, v. 9. n. 105, p.3-25, 1983.

RIBEIRO, L.P.; SANTOS, D.M.B.; LIMA NETO, I. A. Levantamento detalhado dos solos, capacidade de uso e classificação de terras para irrigação da estação de plasticultura da universidade federal da Bahia/Politeno em Cruz das Almas (BA). Revista Brasileira de Ciência do Solo, v. 19, n. 1, p. 105-113, 1995.

RICCI, M.; PETRI, S. Princípios de aerofotogrametria e interpretação Geológica. São Paulo, Editora Nacional, 1965. 226p.

ROCHA, A.; RICHTER, E.H.; SOUZA, S.R.B.P. et al. Utilização de técnicas de sensoriamento remoto e geoprocessamento para avaliação da evolução do uso do solo em área de proteção ambiental: um estudo de caso (compact disc) ' In: SIMPÓSIO BRASILEIRO DE SENSORIAMENTO REMOTO, 8., Salvador, 1996.

RODRIGUES, M. Introdução ao geoprocessamento. In: SIMPÓSIO BRASILEIRO DE GEOPROCESSAMENTO, São Paulo, 1990. Geoprocessamento; anais. São Paulo, USP, Escola Politécnica, 1990.p1-26.

SANCHEZ, M.C.; GERARDI, L.H.O. Fotointerpretação e quantificação para avaliação de transformações no uso da terra. Geografia, v.15 16, n. 8, p. 143-150, out.1983. 
SANO, E.E.; ASSAD, E.D.; MOREIRA, L.; MACEDO, J.; STONER, E. Utilização do SIG/INPE na caracterização ambiental dos campos experimentais do CPAC/EMBRAPA. São Paulo: USP-Escola Politecnica. p.273-282. 1990.

SANTOS, A. P. dos; NIERO, M. e LOMBARDO, M.A. Interpretação de dados de sensoriamento remoto no uso da terra. São José dos Campos: INPE, 1980. 318p.

SANTOS, R.Z.; MENDONÇA, F.J.; NEVES, C.C. et al. Aplicação de imagens TM/Landsat na analise temporal do uso da terra a nível de imóvel rural. In: SIMPÓSIO BRASILEIRO DE SENSORIAMENTO REMOTO, 5., Natal, 1988. Anais. v.1, p.118-123.

SILVA, J.R.C.; DEGLORIA, S.D.; PHILIPSON, W.R.; et al. Estudos da mudança de uso da terra através de um sistema de análise georreferenciada. Revista Brasileira de Ciência do Solo, v. 17, n.3, p. 451-457, set/dez. 1993.

SPAROVEK, G. (Coord). Plano diretor da Microbacia do Córrego do Ceveiro Piracicaba: ESALQ, 1991. v.1: Diagnóstico da situação, levantamento de problemas e propostas de solução, $286 \mathrm{p}$.

SPAROVEK, G.; LEPSCH, I.F. Diagnóstico de uso e aptidão das terras agrícolas de Piracicaba. Piracicaba: ESALQ, 1992.

SPAROVEK, G.; LEPSCH, I.F. Diagnóstico de uso e aptidão das terras agrícolas de Piracicaba. In: TAUK-TORNISIELO, S. M.; GOBBI, N.; FORESTI, C. et al. Análise ambiental estratégias e ações. T.A. Queiroz, 1995. Cap. 7, p. 273-280. 
SPAROVEK, G.; jong van LIER, Q. Estimativa da tolerância de perda de terra por erosão. CONGRESSO BRASILEIRO DE CIENCIA DO SOLO, 14., Goiânia, 1993. Goiânia: SBCS, 1993. v. 3, p. 165-166.

STEIN, D.P Potencial de erosão laminar natural e antrópico, na bacia do Peixe-Paranapanema. In: SIMPÓSIO NACIONAL DE CONTROLE DE EROSÃO, 4., Marília, 1987. Anais. Marilia: ABGE, 1987. p.105-135.

STEINER, D. Time dimension for crop surveys from space. Photogrametric Engineering, v. 31, p. 269-280. 1970.

SUARES DE CASTRO, F. Conservacion de suelos. 3. ed. San José: IICA, 1980. 315p.

TEIXEIRA, A.I.A.; ROCHNOW, M.C.R.; SUAREZ, R; CARDOSO, S. Determinação das áreas de risco de erosão na Bacia do Córrego Monjolo Grande (SP), através de um SIG. In: SIMPÓSIO BRASILEIRO DE GEOPROCESSAMENTO, São Paulo, 1990. Geoprocessamento: anais. São Paulo, USP, Escola Politécnica, 1990. p. 300307.

TEXEIRA, A.L.; MORETTI, E.; CHRISTOFOLETTI, A. Introdução aos Sistemas de Informação Geográfica. Rio Claro: UNESP, 1992. 80p.

VALENTE, O.F. Manejo de bacias hidrográficas. Saneamento, v. 50, n. 2, p. 104-109, abr.jun. 1976.

VETTORAZZI, C.A. Sensoriamento remoto orbital. Piracicaba: ESALQ, Departamento de Engenharia Rural. 1992. 134 p. (Série Didática 2) 
WISCHMEIER, W.H. A rainfall erosion index for a universal soil-loss equation. Soil Science Society of America Proceedings, v.23, p.246-249, 1959.

WISCHMEIER, W.H.; MANNERING, J.W. Relation of soil properties to its erodibility. Soil Science Society of America Proceedings, v.33, p. 131-137, 1969.

WISCHMEIER, W.H.; JOHNSON C.B.; CROSS B.V. A Soil Erodibility Nomograph for Farmland and Construction Sites. Journal of Soil Water Conservation. v.26, p. 189-193, 1971.

WISCHMEIER, W.H.; SMITH, D.D. Predicting rainfall erosion losses: a guide planning. Washington: USDA, 1978. 58p. (Handbook, 537).

WISCHMEIER, W.H.; SMITH, D.D. Rainfall energy and its relationships to soil-loss. Transactions American Geophysical Union. v.39, n.2, p.285-291, 1958.

YOUNG, A. Tropical soils and soil survey. Cambridge: Cambridge University Press, 1976. $468 \mathrm{p}$. 